CURSO DE ESPECIALIZAÇÃO EM DESENVOLVIMENTO HUMANO, EDUCAÇÃO E INCLUSÃO ESCOLAR - UAB/UNB

\title{
A APRENDIZAGEM MATEMÁTICA NO CONTEXTO DA SALA DE RECURSOS: INTERAÇÕES E ADEQUAÇÕES CURRICULARES NO PROCESSO ENSINO-APRENDIZAGEM
}

Raimunda Maria de Oliveira

Orientadora: Profa. Dra. Gabriela Sousa de Melo Mieto 
Universidade de Brasília - UnB

Instituto de Psicologia - IP

Departamento de Psicologia Escolar e do Desenvolvimento - PED

Programa de Pós-Graduação em Processos de Desenvolvimento Humano e Saúde PGPDS

\section{A APRENDIZAGEM MATEMÁTICA NO CONTEXTO DA SALA DE RECURSOS: INTERAÇÕES E ADEQUAÇÕES CURRICULARES NO PROCESSO ENSINO-APRENDIZAGEM}

Monografia apresentada ao Curso de Especialização em Desenvolvimento Humano, Educação e Inclusão Escolar, do Depto. De Psicologia Escolar e do Desenvolvimento Humano - PED/IP - UAB/UNB

Orientadora: Profa. Dra. Gabriela Sousa de Melo Mieto

Brasília - 2011 


\title{
A APRENDIZAGEM MATEMÁTICA NO CONTEXTO DA SALA DE RECURSOS: INTERAÇÕES E ADEQUAÇÕES CURRICULARES NO PROCESSO ENSINO-APRENDIZAGEM
}

\begin{abstract}
Monografia aprovada como requisito parcial para obtenção do grau de Especialista do Curso de Especialização em Desenvolvimento Humano, Educação e Inclusão Escolar - UAB/UNB. Apresentação ocorrida em /2011.

Aprovada pela banca formada pelos professores:
\end{abstract}

Dra. Gabriela Sousa de Melo Mieto (Orientadora)

Cleia Alves Nogueira - (Examinadora)

Raimunda Maria de Oliveira (Cursista)

BRASÍLIA/2011 


\section{Dedicatória}

Ao Criador que criou o mundo, para conservá-lo, amá-lo e vivermos de forma digna e fraterna.

Aos meus pais, a quem devo a formação do meu bom caráter.

Aos meus amigos, sempre presentes.

À Aninha, afilhada querida, que preenche a minha vida de mãe.

Aos queridos alunos que permitiram a total inclusão em minha vida.

Aos queridos educadores que contribuíram para minha formação acadêmica inclusiva.

À Carlos Mota (in memorian), grande educador, que me fez refletir sobre a importância da vida, do registro e das nossas escolhas profissionais. 


\section{AGRADECIMENTOS}

Renda-se, como eu me rendi. Mergulhe no que você não conhece como eu mergulhei. Não se preocupe em entender, viver ultrapassa qualquer entendimento.

Clarice Lispector

Parafraseando Clarice Lispector:

\section{Educar ultrapassa qualquer entendimento.}

Não há lógica matemática que explique as tantas incógnitas indecifráveis quando entramos no espaço escolar. As incertezas nos acompanham e por mais que tenhamos números que indiquem "sucessos" ou "fracassos", cada um(a) constrói sua própria história. Uma história que nunca é solitária. Das experiências compartilhadas surgem as dúvidas, as certezas, criam-se mais histórias - de vida pessoal, de mundo. Um mundo que não se faz sozinho. É compartilhado o tempo todo. A voz do mundo compartilhado nos diz que incluir pessoas é também incluir ideias que de alguma forma, irão compor uma nova história. Ainda que nos separemos em dado momento, essa história compartilhada novamente será compartilhada por outra pessoa, por muitas pessoas, num processo contínuo, formando novas histórias: de mundos, de pessoas. Ideias compartilhadas transformam pessoas, transformam o mundo. A solidão não é amiga da educação. É assim que pretendo construir minha trajetória de vida pessoal e profissional: inacabada realimentada, agradecendo sempre:

À Deus que escreveu a minha história, com acertos e desacertos da condição de Ser... Humana.

Aos meus pais, que infelizmente não tiveram a oportunidade de concluir seus estudos, mas não abriram mão da minha educação, pois sabiam, intuitivamente, o quanto seria uma jornada apaixonante para mim! Meu pai, a herança matemática. Minha mãe, a primeira 
leitura, as primeiras letras, antes de embarcar no mundo encantado da curiosidade, da aprendizagem. Pais são sempre nossa fortaleza!

A todos aqueles que fizeram parte da minha vida, pessoal e profissional. Amigos inesquecíveis, grandes incentivadores!

À Ana Júlia e Pedro que, de uma forma tão especial entraram em meu trabalho, antes em minha vida, e compartilharam, além dos números e problemas matemáticos, suas dúvidas, seus encantos. Ensinaram-me a aprender com as diferenças.

\section{À possibilidade de compartilhar.}

Compartilhar significa também, abrir-se para amigas/amigos de trabalho e de tantos cursos, que elevaram a minha condição de ser simples professora, para a condição de professora/educadora/pesquisadora que também precisa aprender. Nomes? Elas/Eles já sabem. Injusto se nesse momento esquecesse alguém. Todos, ontem ou hoje, são parte da minha formação. Obrigada!

À Professora Dra. Gabriela, orientadora, que na primeira especialização à distância, soube extrair de mim e estimular a conclusão desse trabalho diante de dificuldades e imprevistos, num curso que ressignificou o meu jeito de estudar. Não foi fácil quebrar esse paradigma. Obrigada pela acolhida!

À $\boldsymbol{U A B / U N B}$, através dos(as) professores(as), coordenadores(as), que proporcionaram uma jornada acadêmica rompendo barreiras e preconceitos em fazer um curso à distância. Experiência enriquecedora e desafiante!

À Fernanda, tutora à distância, pelo incentivo e estímulo, quando carinhosamente elogiava meus escritos.

À Elizianne e ao Fausto, tutores presenciais, sempre acolhedores nos encontros presenciais, transformando-nos num grupo, apesar da distância.

À Neide, querida, que carinhosa e respeitosamente, revisou todo o meu trabalho. 
Especialmente à querida amiga Tatiana, que num incentivo mútuo, embarcou nessa jornada e construímos uma sólida parceria acadêmica, desdobrada em outros cursos e congressos. Vigotski certamente apreciaria saber que essa relação se fez a partir das interações sociais no ambiente escolar.

Enfim, esqueci alguém? Considere-se desde já lembrado, pois essa incógnita teremos que decifrar na próxima jornada. Espero eu, no mestrado.

Há sempre um lugar há mais para incluir...

Meus sinceros agradecimentos. 


\section{RESUMO}

Essa pesquisa tem como objetivo analisar estratégias que favoreçam a aprendizagem matemática de estudantes com necessidades educacionais especiais, atendidos em Sala de Recursos; considerando que o enfoque sócio-cultural que é dado à educação matemática na atualidade pode favorecer a aprendizagem desses(as) estudantes. Assim faz-se necessário compreender: os aspectos legais que tratam da Educação Especial na perspectiva da Educação Inclusiva e como é entendida na escola; a influência de Vigotski na aprendizagem matemática, bem como o papel da interação e sua interferência na construção do conhecimento matemático; a importância da inclusão nesse processo de aprendizagem e as adequações curriculares como uma medida fundamental para facilitar a aprendizagem dos(as) estudantes que apresentam alguma necessidade especial. Nessa pesquisa foram empregados referenciais teóricos baseados principalmente em Vigotski e seus seguidores. A metodologia escolhida para a realização da presente pesquisa foi a qualitativa por entendermos que ela abrange os vários aspectos que envolvem uma aprendizagem que tenha em seu cerne o aspecto dialógico, onde a pesquisadora é elemento importante nessa construção, também como sujeito que dialoga com o mundo. A partir desse entendimento, foram propostas atividades realizadas em aula regular, apoiadas em condições contextuais e pedagógicas diferentes. Dos resultados encontrados, pôde-se concluir, ao final, que o processo de interação é facilitador da aprendizagem, muito embora ele por si só não funcione sozinho.

Palavras-chaves: Aprendizagem matemática; educação inclusiva; interação, adequações curriculares; Vigotski. 


\section{SUMÁRIO}

APRESENTAÇÃO ........................................................................................................ 1

1 - FUNDAMENTAÇÃO TEÓRICA............................................................................... 8

1.1. A importância de Vigotski no estudo da deficiência .................................................................. 8

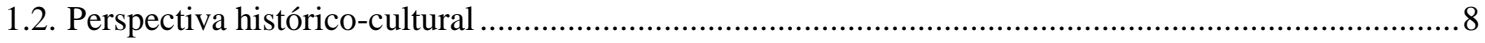

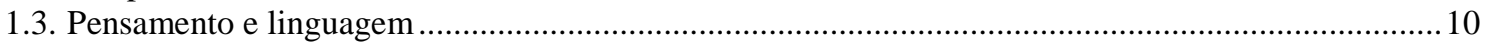

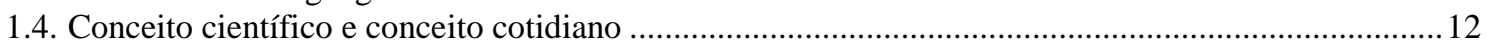

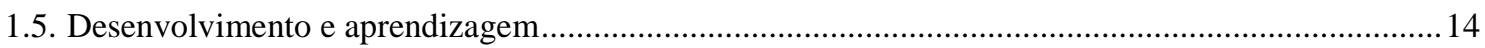

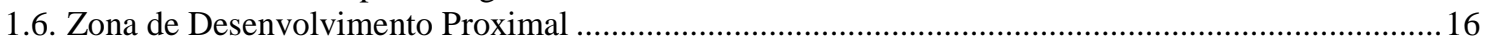

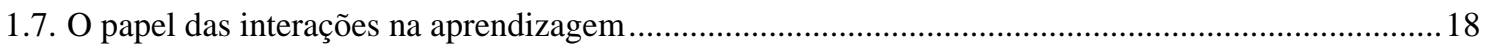

2 - A EDUCAÇÃO ESPECIAL NO BRASIL ............................................................. 20

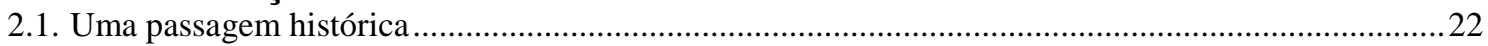

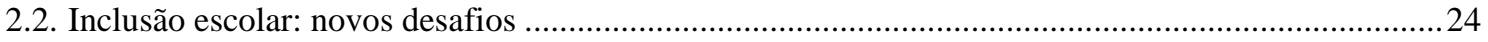

2.3. A Sala de Recursos e atribuições do professor no contexto do Distrito Federal ...............................25

2.3.1. Atribuições de todos(as) os(as) profissionais que atuam em Sala de Recursos..........................28

2.3.2. Atribuições dos(as) docentes das Salas de Recursos Generalistas ...........................................30

2.4. A concepção curricular na perspectiva da educação inclusiva: adequações curriculares ....................32

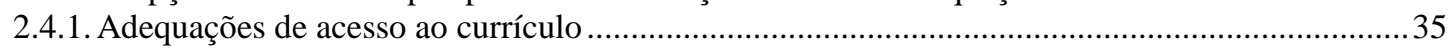

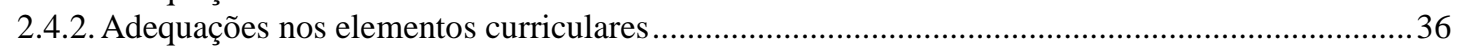

2.4.2.1. Adequações metodológicas e didáticas ............................................................... 37

2.4.2.2. Adequação dos conteúdos curriculares e do processo avaliativo ............................ 37

2.4.2.3. Adequações curriculares: uma reflexão importante ................................................ 38

\section{3 - O (A) ESTUDANTE COM DEFICIÊNCIA INTELECTUAL NO AMBIENTE} ESCOLAR: CONHECENDO E ENTENDENDO SUAS POTENCIALIDADES . 40

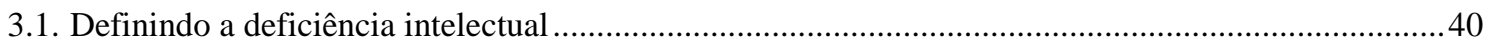

3.2. Sobre a nomenclatura deficiência mental/deficiência intelectual .................................................41

3.3. O desafio da escola em estimular o sujeito com deficiência intelectual .........................................43

4 - A APRENDIZAGEM MATEMÁTICA .................................................................... 45

4.1. O conhecimento matemático numa perspectiva sócio-histórica......................................................46

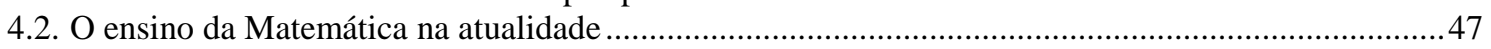

4.3. O educador matemático em uma mediação diferente ......................................................................48

4.4. O processo de resolução de problemas para o(a) estudante com deficiência intelectual ....................53

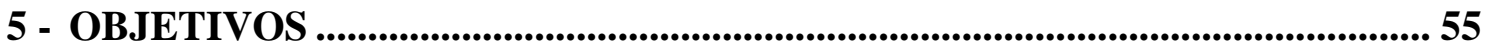

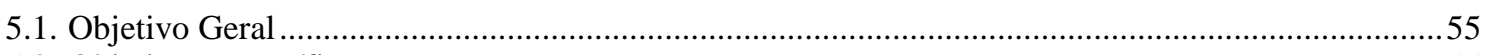

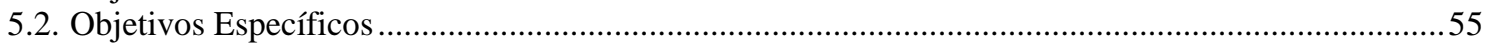

6 - METODOLOGIA...................................................................................................... 56

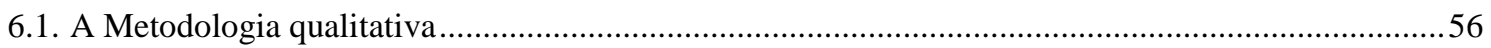

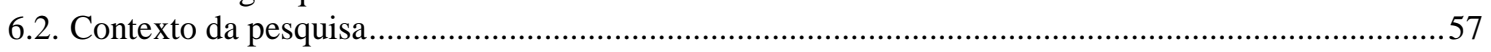

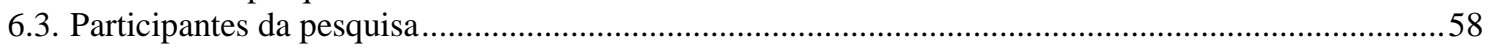

6.4. Procedimentos de construção de informações .....................................................................

6.5. Instrumento de pesquisa, técnicas e materiais utilizados ..........................................................60

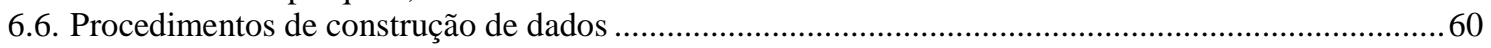


6.7. Procedimentos de análise dos dados.

CONSIDERAÇÕES FINAIS................................................................................. 82

REFERÊNCIA BIBLIOGRÁFICA............................................................................. 86

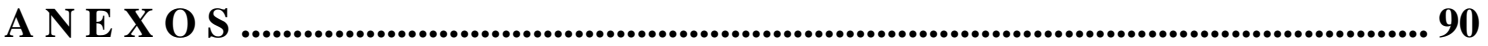


Por tanto amor

Por tanta emoção

A vida me fez assim

Doce ou atroz

Manso ou feroz

Eu! Caçador de Mim...

Preso a canções

Entregue a paixões

Que nunca tiveram fim

Vou me encontrar

Longe do meu lugar

Eu! Caçador de Mim...

Nada a temer

Senão o correr da luta Nada a fazer

Senão esquecer o medo

Abrir o peito à força

Numa procura

Fugir às armadilhas

Da mata escura...

Longe se vai

Sonhando demais

Mas onde se chega assim?

Vou descobrir

$\mathrm{O}$ que me faz sentir

Eu! Caçador de Mim...

Nada a temer

Senão o correr da luta

Nada a fazer

Senão esquecer o medo

Abrir o peito à força

Numa procura

Fugir às armadilhas

Da mata escura...

Longe se vai

Sonhando demais

Mas onde se chega assim?

Vou descobrir

$\mathrm{O}$ que me faz sentir

Eu! Caçador de Mim!

Eu! Caçador de Mim!

$\mathrm{Eu} ! .$.

Caçador de Mim (para mim, imortalizada na voz de Milton Nascimento)

Luiz Carlos Sá - Sérgio Magrão 


\section{APRESENTAÇÃO}

\section{"A vida me fez assim..."}

Nasci num lugar longínquo, perdido, desconhecido.

Seu nome? Pedro II.

Muitos nem ouviram falar! É conhecida como Suíça Piauiense, a mais fria das cidades do Piauí, cercada pela Serra dos Matões e distante de Terezina 195 km.

Quem lá habita convive com uns "poucos' 30 mil habitantes. E quando todos pensam, que pela sua falta de popularidade é tão insignificante, esse "estranho" município é conhecido como a Terra do Opala, pedra preciosa que durante décadas foi explorada somente em minas localizadas na Austrália. Atualmente, quem diria, o Brasil é o principal produtor mundial.

Como em outras cidades do nordeste possui grande potencial artesanal e é na praça Domingos Mourão onde acontecem as oficinas de artesanato.

\section{Bordado, crochê, rede para deitar \\ E sonhar... \\ Com o descanso, o silêncio, \\ A tranquilidade \\ Existente por lá.}

E foi nessa tranqüilidade de vida interiorana que nasci, no dia 15 de fevereiro.

De parteira vim ao mundo, quando meu pai estava em Brasília procurando oportunidades.

Minha mãe cuidava de mim, linda e "carequinha", e da minha única irmã, quando resolvemos fazer nossa primeira viagem de avião, nem me recordo da sensação, era tão bebê!

Encontramo-nos com papai e em Brasília residimos, desde então.

E aquela velha pergunta que sempre fica no ar: em que ano esse espetáculo de pessoa veio ao mundo?

Números, números...

Que importam esses valores?

Os anos continuam existindo e a minha vida também.

Espero viver muito!

Essa variável numérica, que às vezes assusta quando nos olhamos diante do espelho também revela a beleza da maturidade.

Espero viver muito! 
Embora esse dia inevitavelmente chegue, não gostaria de deixar essa existência sem decifrar as infinitas incógnitas que ainda passarão pela minha vida.

\author{
"Preso a canções \\ Entregue a paixões \\ Que nunca tiveram fim \\ Vou me encontrar \\ Longe do meu lugar \\ Eu! Caçador de mim...”"
}

Conhecer-me um pouquinho mais, sem exageros zoodiacais ou excessiva vaidade, parece que aquário descreve muito do que sou:

\author{
Especial magnetismo \\ Nunca passa despercebida \\ Instável, explosiva, misteriosa \\ Por vezes, várias mulheres numa só \\ Sua inquietude \\ Persegue sua vida \\ E a liberdade é o seu lema \\ É vivaz e generosa \\ Signo do ar \\ Necessita de espaço \\ para voar.
}

Gratas recordações nessa minha existência. Outras que, certamente, a memória fez questão de apagar, para que lembrar?

Amizades que perduram até hoje e já completaram até bodas de prata!

Uma grande paixão, que para muitos chega ao exagero, é a Nina. Desconheço uma relação tão verdadeira quanto esta: símbolo de lealdade, amizade, companheirismo. De quem se trata? Da inexplicável convivência nasce um amor incondicional. Um olhar que acompanha, um gesto que surpreende. Não fala, mas expressa sentimentos que só pessoas sensíveis conseguem decifrar. Em grande parte da minha existência está presente esse apaixonante ser, embora tenhamos que nos preparar para a inevitável separação, processo natural da condição de ser. Descrevê-la nem precisa. Basta compreender seus olhos pedindo carinho e a sua recepção quando estou muito tempo ausente. É assim a Nina, uma linda pequinês, quase em extinção, pouca gente conhece. Seu focinho, ninguém vê e de tão pequenino vive a roncar, mesmo acordada. Não lambe. Para ser diferente, cheira, reconhecendo sua família, seus amores! Entender mais 
essa paixão? Vale assistir o filme ou ler o livro Marley \& Eu. Se ainda assim não se convencer, eis outra incógnita para decifrar.

E a matemática? Em que momento entrou em minha vida?

Parece estranho hoje assumir esse posto de professora. Mais estranho ainda, professora de matemática.

Embora, essa afinidade com os números, incógnitas e formas fosse uma constante em minha vida acadêmica, não era sonho, nem desejo. Creio que foi herança do meu pai (sem deixar de ressaltar valores imprescindíveis na minha formação como pessoa e que representa muito do que sou) e meu grande orgulho. Mesmo analfabeto, brilhante nos cálculos; indiscutivelmente, a prova de que vida e grandes necessidades nos oferecem oportunidades de aprendizagem e conhecimentos que estão longe dos bancos de escola. Ele é um mestre na arte de conversar e seduzir com os seus assuntos, sempre muito bem informado.

Mamãe, como não poderia deixar de ser, foi presença marcante no meu processo de aprendizagem. Antes de frequentar a escola foi ela quem me alfabetizou.

E essa história de números, letras? Lembro-me de como eu gostava de anteciparme aos professores de matemática e fazer os exercícios antes do assunto ser explicado. Achava o máximo o espanto deles quando lhes mostrava tudo feito; embora muito dedicada como aluna, sempre fui muito tímida na escola.

Mais tarde, grande confusão foi quando escolhi o curso de Construção Civil - $2^{\circ}$ grau - num colégio público do DF. Influência do trabalho de papai, pois queria ser uma grande arquiteta! O que marcou esse período? Poderia dizer que os momentos de prazer acadêmico ficavam a cargo das aulas de desenho geométrico. Sempre gostei de desenhar, embora a criação não seja o meu forte. Quando precisei utilizar aquela régua $\mathbf{T}$, que carregava timidamente no ônibus, pensei que seria mais difícil. Adorava o resultado das fachadas que criava.

Muitos momentos não-acadêmicos desse período estão arquivados na memória. Do que me lembro desse período são as agradáveis lembranças musicais na voz de C.T. (outra incógnita).

“... Eu só queria ter do mato

Um gosto de framboesa

Pra correr entre os canteiros

E esconder minha tristeza

E eu ainda sou bem moço pra tanta tristeza...

E deixemos de coisa, cuidemos da vida 


\section{Senão chega a morte \\ Ou coisa parecida \\ E nos arrasta moço \\ Sem ter visto a vida..."}

(Fagner. Canteiros, 1973)

Fagner era presença marcante nos momentos de descontração da escola. Meu amigo C.T. era apreciador de músicas e tocava muito bem violão - seu amigo inseparável - e era um grande poeta. O que poderia ser mais prazeroso? Abrindo os arquivos da memória, minha primeira grande paixão de adolescente, o R. (outra incógnita). Decifrá-las? Para quê? Processo natural da condição humana. O ir e vir do coração, mesmo diante da razão!

Daí em diante, o término do $2^{\circ}$ Grau e a expectativa do vestibular.

Não conquistei a tão sonhada vaga na UNB, então resolvi atirar-me nos números complexos, nas derivadas, integrais e outras coisas que não conseguiram me seduzir-me na Faculdade, a não ser o meu amado professor $\mathbf{L}$, encantador, com o seu jeitinho doce de ensinar e $\mathbf{A}$, grande mestre, organizado como nunca vi! Talvez seja por isso que só assumi meu posto de professora após cinco anos de conclusão do curso de graduação (trabalhava em órgão público - processo de acomodação). Realmente não foi um curso dos mais sedutores.

As voltas que o mundo dá! Hoje entendo porque as aulas não me fascinavam. Era tudo muito técnico, mecânico, teórico - fico pensando nos meus alunos! Só despertei para o gosto de ensinar quando conheci o professor $\mathbf{C M}$ e a professora $\mathbf{N B}$, na UNB. Esses sim, grandes mestres e exemplos na minha formação.

Quando comecei a fazer cursos na UNB, fiquei diante de uma outra realidade e percebi o quanto as minhas aulas eram chatas - nem sei se melhorou tanto assim; como estava despreparada para lidar com alunos, conteúdos, greves, política - realidade diferente dos papéis, da burocracia, do previsível da função que exercia no funcionalismo público. Acordei enfim! Precisava investir na minha formação acadêmica, pois a dinâmica do trabalho em sala de aula despertou algo que desconhecia sobre mim mesma: papel, previsibilidade de tarefas a serem cumpridas diariamente, nada disso combinava com a minha inquietude. Ensinar é da ordem do imprevisível, isso é fascinante! Por mais que estejamos preparados, que tenhamos aulas definidas e bem planejadas, a convivência humana é dotada de incertezas. Muito sedutor! Talvez explique a existência das incógnitas, das variáveis. Para quem não consegue perceber a 
utilidade das equações na vida diária, os acontecimentos da vida às vezes nos surpreendem e muitos problemas precisam ser solucionados.

\author{
"...Nada a temer \\ Senão o correr da luta \\ Nada a fazer \\ Senão esquecer o medo \\ Abrir o peito à força \\ Numa procura \\ Fugir às armadilhas \\ Da mata escura..."
}

Diante desse universo imprevisível que é o ato de ensinar, alguns questionamentos da minha escolha profissional e crises de incertezas, conheci aquele que ressuscitou em mim o desejo de ser professora. Completando 18 anos de atividade docente (incluindo passagem de 6 anos em instituição particular), tive o privilégio de trabalhar com o único "gestor de escola" (desculpe-me os outros que não tive a oportunidade de conhecer) que efetivamente cumpria a função pedagógica que o cargo exige. Apaixonado pela educação e contagiante nas suas ações, esse era o professor CM. Reviver as alegrias do trabalho acadêmico na formação e na prática docente é importante nas reflexões futuras desse trabalho monográfico e não poderia deixar de mencionar que todo esse "encantamento" pela educação teve uma trágica interrupção. Uma vida cheia de idéias e compromisso pedagógico que iam além do discurso.

Diante da incerteza do ato de ensinar, uma oportunidade nova de trabalho: Sala de Recursos - atendimento educacional especializado para estudantes com necessidades especiais. Além de mais incertezas, a fragilidade de um sistema (professores e todos aqueles que estão envolvidos direta ou indiretamente com a escola) que não se preparou para lidar com a inclusão como ela é preconizada. Inclusão lembra as ações do professor CM e falar a seu respeito é uma licença poética, pois estava muito à frente, como muitos outros educadores que fizeram história na educação brasileira. Descrever minha trajetória acadêmica e profissional sem mencionar esse grande mestre, seria construir uma obra mais inacabada do que pretende ao final, pois muitos outros questionamentos surgirão e possivelmente ficarão sem respostas.

Escrever a própria história, rever a própria trajetória de vida pessoal e profissional e aprofundar a reflexão por meio desse trabalho é também um exercício de autoconhecimento, extremamente necessário para quem pretende valorizar e estimular 
outras pessoas. Não tenho o talento dos poetas e dos escritores para escrever, mas a minha inquietude precisa gritar, um começo e não um fim.

\author{
"... Longe se vai \\ Sonhando demais \\ Mas onde se chega assim? \\ Vou descobrir \\ O que me faz sentir \\ Eu! Caçador de Mim..."
}

E eis que começa essa nova etapa a partir do trabalho desenvolvido na Sala de Recursos da escola pesquisada. Por meio dessa monografia, com a licença acadêmica que exige um olhar técnico sem deixar meu jeito próprio de enxergar o ato de educar, tentar compreender o que está por trás da aprendizagem Matemática de estudantes que frequentam Sala de Recursos - através das interações e adequações que são necessárias para o avanço acadêmico -, considerando a realidade do sistema educacional brasileiro, numa persectiva inclusiva e, ainda, respeitando meu jeito próprio de ser e compreender a educação - educar para ler e compreender o mundo, educar para conhecer a beleza das ciências nas suas mais variadas formas, educar para reconhercer-se no espaço geográfico e histórico, educar com amor, educar para conviver em sociedade de forma harmônica, educar para... "SER".

Assim o objetivo principal dessa pesquisa é analisar que estratégias, por meio das adequações curriculares favorecem a aprendizagem matemática de estudantes com necessidades educacionais especiais, atendidos em Sala de Recursos. Para isso é preciso compreender o papel das interações numa perspectiva vigotskiana e outros estudos abordados por esse autor que contribuirão de forma significativa no percurso desse trabalho.

O capítulo I constitui uma explanação das principais ideias de Vigotski e seus seguidores, sua importância para o estudo da deficiência, o papel das relações entre desenvolvimento e aprendizagem, a abordagem histórico-cultural do desenvolvimento humano, a relação entre conceito científico e conceito cotidiano e suas implicações para a aprendizagem, o conceito de zona de desenvolvimento proximal e sua contribuição para esse estudo e o papel das interações na aprendizagem.

O capítulo II faz uma viagem percorrendo a história da Educação Especial no Brasil, destacando as principais mudanças até os dias atuais. Apresenta também como tem sido o atendimento dos(as) estudantes com necessidades educacionais especiais na 
Secretaria de Estado de Educação do Distrito Federal e como se dá o atendimento educacional especializado. O foco dessa seção é conhecer o trabalho realizado nas Salas de Recursos, bem como as atribuições dos profissionais que atuam nessa área e sua formação.

Quanto ao capítulo III, traz à luz do nosso conhecimento questões importantes sobre a deficiência intelectual. Trata da mudança de nomenclatura e esclarecimentos quantos às características dos(as) estudantes com deficiência intelectual e como estimular esse sujeito para que seja bem-sucedido na escola.

O capítulo IV foi dedicado ao estudo da matemática, com foco na contribuição de Vigotski para o ensino da mesma; faz algumas considerações a respeito da mudança no ensino da matemática na atualidade e propõe a resolução de problemas como um eixo norteador do trabalho do professor para facilitar aprendizagem do(a) estudante com deficiência intelectual.

No capítulo V são abordados os objetivos dessa pesquisa, de forma sucinta.

O capítulo VI nos possibilita conhecer a metodologia escolhida para o desenvolvimento da pesquisa, em que contexto está inserida, quem são os participantes e os instrumentos e técnicas utilizados. A partir daí retrata os procedimentos de análise e resultados que são apresentados por meio de tabelas e síntese das observações das atividades realizadas com os participantes.

Além das seções apresentadas em cada capítulo, as reflexões a respeito desse estudo, apresentadas nas considerações finais, comprovam a relevência da promoção de atividades compartilhadas no ambiente escolar e que elas propiciam uma grande oportunidade de aprendizagem para o (a) estudante com deficiência intelectual.

Por fim, os anexos que compõem instrumentos importantes para a análise dos resultados que foram apresentados. Vale a pena ler e analisá-los. Complementam os estudos feitos. 


\section{1 - FUNDAMENTAÇÃO TEÓRICA}

\subsection{A importância de Vigotski no estudo da deficiência}

Para Vigotski (1995, apud ABREU, 2006, p. 20), "no desenvolvimento complicado por um defeito, um fator importante à dupla influência orgânica no processo deste desenvolvimento e a formação da personalidade da criança”. Segundo conclusões da presente autora, em parte o defeito pode ser limitador, mas por outro lado estimula o desenvolvimento. $\mathrm{O}$ defeito estimula a formação de compensação.

A escolha para o referencial teórico, fundamentado na obra de Vigotski dá-se pela sua contribuição ao abordar a importância dos fatores socioculturais, as interações entre pares, a mediação, processo de internalização, a zona de desenvolvimento proximal, a formação de conceitos nesses estudos. Vigotski (idem) assegura que as conseqüências sociais definem o destino da personalidade com deficiência. À medida que os estudos avançam, compreende-se que a deficiência não impede o indivíduo de aprender; ele apenas necessita de mecanismos, talvez mais consistentes, que proporcionem um melhor desempenho acadêmico e que reflitam na sua vida social e cultural.

\subsection{Perspectiva histórico-cultural}

Ao lidar com a escola, mesmo diante da diversidade que nela se encontra, parece automática, ao entrar em sala de aula com exercícios, textos e conteúdos previamente selecionados de acordo com o programa previsto, a idéia de que as informações "passadas" serão apreendidas da mesma forma por todos. Toda a organização pedagógica pressupõe uma estrutura curricular e avaliativa fechada de tal forma, que o tempo de aprendizagem seja o mesmo - com começo, meio e fim, como se os(as) estudantes fossem dotados(as) da mesma capacidade cognitiva e pudesse determinar o tempo de aprendizagem de cada um(a). Das discussões e leis que surgiram garantindo a inclusão e permanência de pessoas com necessidades especiais modificando o cenário educacional, pouca coisa mudou na organização escolar - seja no espaço físico, seja na estrutura pedagógica: conteúdos, avaliações, planejamento, ou ainda, corroborando a "falsa" idéia de que na escola os grupos são homogêneos. Todas as modificações legais trouxeram consigo certo “desconforto". As aulas e livros didáticos já não respondem a 
essa nova demanda e perfil de estudantes que se encontra no ambiente escolar. A sociedade mudou e a escola continua com o mesmo formato. Cada vez mais se faz necessário embasamento para poder fundamentar melhor uma prática pedagógica que dê conta das mudanças e garanta um ensino de qualidade para todos(as) (SILVA, RIBEIRO, MIETO, 2010).

Ao considerar que a escola é um espaço de diversidade, faz-se necessário compreender que:

\begin{abstract}
[...] as contribuições da perspectiva histórico cultural sobre o desenvolvimento humano são pertinentes para ampliar essa discussão, pois trazem questões relevantes sobre o papel da cultura na formação subjetiva, bem como reflexões importantes acerca das pessoas que apresentam necessidades educacionais especiais (VIGOTSKI, 1989,1993, 1994, 2000). (Ibidem, p. 206).
\end{abstract}

Silva, Ribeiro e Mieto (2010), confirmam a importância das relações interpessoais em seu texto. A forma como os pares se relacionam, o que pensam, como agem e a leitura que se faz do mundo têm relação com as condições sociais que lhes são ofertadas, culturalmente falando. Não há lugar melhor que a escola que comprove a veracidade desse fato. A instituição de ensino que é parte dessa pesquisa, por meio dos(as) estudantes observados(as), tem em seu universo a presença dessa diversidade cultural e é fácil perceber que as dificuldades de aprendizagem encontradas, na maioria das vezes, estão relacionadas a fatores culturais e familiares ${ }^{1}$. Há uma grande quantidade de estudantes que reside em comunidade carente, onde a maioria se concentra no $6^{\circ}$ e $7^{\circ}$ anos do ensino fundamental. A partir daí, nas séries seguintes $\left(8^{\circ} \mathrm{e}\right.$ $9^{\circ}$ anos), esse grupo diminui: seja pela desistência e abandono ou por repetência escolar; e o perfil da escola vai se modificando nas séries finais do ensino fundamental. A escola como "lócus" de interação natural deveria ser menos excludente. Entretanto, contraditoriamente, percebe-se que a discussão que permeia os estudos relativos à inclusão escolar, suas leis e formas de organização social, familiar, têm tentado de alguma forma mudar esse cenário escolar, ainda tão atual. Ensinar e aprender, nessa perspectiva nos impõe o desafio de trabalhar o mais próximo possível do outro. “[...]

\footnotetext{
${ }^{1}$ Não posso afirmar tal fato com absoluta certeza, mas há indícios. Esse é um tópico a ser pesquisado posteriormente. Tenho observado que grande parte dos(as) estudantes com deficiência intelectual pertence a uma classe social menos favorecida em seus aspectos econômicos. É o retrato da escola onde trabalho.
} 
processos psicológicos superiores (imaginação, memória, percepção etc.) é dependente das relações que o sujeito estabelece com a história e a cultura de seu grupo social, por meio da palavra" (Ibidem, p. 208).

Dentro dessa abordagem histórico-cultural, seguindo as ideias principais de Vigotski, temos que "[...] o mecanismo de mudança individual ao longo do desenvolvimento tem sua raiz na sociedade e na cultura” (VIGOTSKI, 2007). Assim, tornar-se humano resulta de uma interação dialética entre homem, sociedade e cultura.

Ao refletir a respeito de Vigotski e seus estudos é possível dizer, de alguma forma, ao observar as ações, linguagem, formas de pensar do(a) deficiente intelectual, que estas pessoas passam também pelo mesmo processo. Desta forma, é possível afirmar que o aspecto histórico-cultural influencia muito nesses novos conceitos que surgiram para justificar a deficiência embora ainda se esteja preso aos diagnósticos, como se fossem um fim em si mesmo. Para a escola interessaria muito mais compreender a dinâmica do pensamento das pessoas com deficiência intelectual, bem como a forma como entendem as informações que recebem e como agem diante dessas descobertas, afinal, todos possuem capacidade para aprender.

Vigotski fundou, em 1925, um laboratório de psicologia para crianças com deficiência. Entre seus objetivos buscava compreender a organização psicológica e conduta do(a) deficiente: "Para ele não é o defeito que decide o destino das pessoas, mas, sim, as conseqüências sociais desse defeito" (PADILHA, 2000). Por isso é importante, ao lidar com nossos(as) estudantes, já estigmatizados(as) pela deficiência, que se tenha um "olhar" em busca de alternativas que valorizem o seu potencial. Conhecer a sua história é fundamentalmente significante, fazê-lo interagir com pares também cria alternativas que podem, de alguma forma, retirar "o rótulo" e trazer à luz o que realmente faz sentido na escola: o seu desenvolvimento.

\subsection{Pensamento e linguagem}

Segundo Rego (2009), a relação entre linguagem e o pensamento passa por muitas mudanças ao longo da existência humana. Mesmo com origens diferentes e se desenvolvendo de forma independente, devido à inclusão da criança em dado grupo cultural, pensamento e linguagem se encontram originando um funcionamento psicológico bem mais sofisticado e humano. Para Vigotski (idem, p. 63): 
[...] a capacitação especificamente humana para a linguagem habilita as crianças a providenciarem instrumentos auxiliares na solução de tarefas difíceis, a superarem a ação impulsiva, a planejarem a solução para um problema antes de sua execução e a controlarem seu próprio comportamento. Signos e palavras constituem para as crianças, primeiro e acima de tudo, um meio de contato social com outras pessoas [...].

Dessa forma, tanto as funções primárias quanto as superiores influenciam-se de forma recíproca e são aprimoradas na mediação do sujeito com o meio em que vive, complementa essa idéia, Abreu (2006), ao afirmar que o processo de desenvolvimento dos signos passa por quatro estágios (ibidem):

$1^{\circ}$ - estágio natural ou primitivo - linguagem pré-intelectual e pensamento pré-verbal;

$2^{\circ}$ - psicologia ingênua - experimentação das propriedades físicas do próprio corpo e dos objetos. Considerado o primeiro exercício da inteligência prática;

$3^{\circ}$ - utilização de signos externos - auxiliares na solução de problemas internos;

$4^{\mathrm{o}}$ - crescimento de fora para dentro - as operações externas são interiorizadas e passam por modificações. Aqui a criança inicia o processo de operação mental, a utilizar à lógica, a operar com relações interiores.

Para Yépez, 1997 (ibidem), a linguagem é presença na atividade humana. Dá sentido e significado, é a interação entre indivíduo e sociedade. O significado une pensamento e linguagem. O pensamento é materializado pela palavra. Nesse sentido essa relação é dialógica, não tem função reprodutiva, mas cria-se e interpreta-se o tempo todo. Completando essa idéia, Abreu (2006), afirma que o pensamento e a linguagem por serem características humanas que são construídas a partir de interações com social,

\footnotetext{
possuem um suporte no substrato biológico e podem adquirir formas específicas que caracterizam um dado tipo de processo patológico, de retardamento, ou peculiaridades em função dos aspectos histórico-culturais do contexto onde as pessoas estão inseridas (idem, p. 29).
}

Assim reiterando essa idéia, para Loureiro (em PUCCETTI, 2002, apud, ABREU, 2006) as pessoas com deficiência ou não, podem envolver-se num processo criativo ao fazer, conhecer, exprimir e experimentar, onde a deficiência pode assinalar para outras habilidades e também possibilidades de apropriação de signos.

Dessa forma, ao relacionar-se socialmente com seus pares, acionam-se as funções psicológicas superiores, conforme a natureza da mediação e interação. 
Pensamento e linguagem como fatores importantes no desenvolvimento psíquico humano, principalmente ao relacionar os conceitos científicos presentes na escola, que sistematiza o saber historicamente construído pela humanidade, com os conceitos cotidianos.

\subsection{Conceito científico e conceito cotidiano}

Ao se pensar em procedimentos eficientes que auxiliem estudantes em sua vida acadêmica e lhes permitam compreender o conhecimento que é sistematizado pela escola, é necessário entender como se dá o desenvolvimento dos conceitos científicos e cotidianos. Em relação ao que Vigotski pensava sobre a formação de conceitos, inserido em seus trabalhos, junto com seus colaboradores, cabe destacar as conclusões deste autor a respeito dos conceitos espontâneos e científicos, apresentadas por Moysés (1997):

- Conhecimento espontâneo está relacionado às experiências que as crianças aprendem em seu cotidiano, por meio de contatos com objetos, fatos, fenômenos;

- Quanto aos conhecimentos científicos, entende-se daqueles sistematizados e transmitidos de forma intencional, seguindo uma metodologia específica. Trata-se aqui dos conhecimentos em situação escolar. Vale destacar que:

[...] um conceito se forma não pela interação de associações, mas mediante uma operação intelectual em que todas as funções mentais elementares participam de uma combinação específica. [...] Quando se examina o processo de formação em toda a sua complexidade, este surge como um movimento do pensamento, dentro da pirâmide de conceitos, constantemente oscilando entre duas direções, do particular para o geral e do geral para o particular. (Vygotsky 1987, p. 70, apud Moysés, p. 36).

Como tarefa o(a) professor(a), em sua função, cabe propiciar ao(à) estudante condições para que ele(a), em contato com o objeto, possa relacioná-lo com o conhecimento mais elaborado.

Destacamos o que Vigotski considerava a essência de um ensino direcionado para a compreensão, fator importante na construção da pesquisa, tratado posteriormente em outro capítulo. Temos: 
1. Trabalhar com o(a) estudante. Professor e estudantes trabalhando juntos, em interação.

2. Explicar e dar informações. Ampliar os esquemas mentais já existentes, de forma a modificá-los ou substituí-los por outros mais abrangentes.

3. Questionar e corrigir. A fala foi compreendida? A partir daí corrigir os erros.

4. Saber explicar. A capacidade do(a) estudante expor suas próprias ideias a partir do que foi construído, em interação com o(a) professor(a). Fazer generalizações é um passo adiante.

Esse processo existe pelo seu caráter dinâmico, interativo. A partir dele, fazer as perguntas certas, provocar um desequilíbrio em busca da Zona de Desenvolvimento Proximal (ZDP) ${ }^{2}$. Quando o homem assimila o significado de uma palavra há um domínio da experiência social, que depende também de um conhecimento individual. Esse significado, construído historicamente, ganha um sentido próprio a partir da história de vida de cada um (MOYSÉS, 1997).

Ao tratar dessa questão, Camargo (1998) considera que o processo de formação de conceitos é um ato de pensamento, além de real, complexo, não ensinado por meio do treinamento. O desenvolvimento de conceitos implica no desenvolvimento de funções intelectuais como a atenção, memória lógica, abstração, capacidade de diferenciar e comparar. Assim, ensinar conceitos de forma direta é um trabalho infrutífero, dado por mera repetição. Essas considerações provocam um sentimento de certeza, embora com muitas indagações a respeito do ensino da matemática provocar tanto "fracasso" nas escolas. Parecem endossar as grandes dificuldades do(a) estudante em resolver alguma operação aritmética. Muitos têm facilidade em resolver contas mentalmente, porém ao aplicá-las formalmente comentem erros que contrariam essas certezas. Memorizar a tabuada, por exemplo, não é garantia de saber resolver o algoritmo da multiplicação corretamente. Assim, o(a) professor(a) tem como tarefa principal, fazer o(a) estudante ultrapassar o conhecimento espontâneo. Para Vigotski (MOYSÉS, 1987, p. 38), “[...] o domínio de um nível elevado na esfera dos conceitos científicos eleva, por sua vez, o nível dos conceitos espontâneos”.

\footnotetext{
${ }^{2}$ Estágio do processo de aprendizagem onde o(a) estudante consegue sozinho ou com ajuda de colegas mais adiantados, o que fazia anteriormente com auxílio do(a) professor(a) (VIGOTSKI, 2010). "É um estágio em que a criança traduz do seu desempenho imediato os novos conteúdos e as novas habilidades adquiridas no processo de ensino-aprendizagem, em que ela revela que pode fazer hoje o que ontem não conseguia fazer" (idem, p. X-XI). Posteriormente esse conceito será aprofundado.
} 


\subsection{Desenvolvimento e aprendizagem}

Vigotski (MOYSÉS, 1997) em seus estudos, tratou das relações entre aprendizagem e desenvolvimento. Seus seguidores investigaram nas mais diversas disciplinas e concluíram, entre outras coisas, que "o processo de aprendizagem muda não só o que se pensa conscientemente, mas também os modos como se produz essa reflexão" (BOGAYAVLENSKY e MENCHINSKAYA, 1991, p. 46³ apud MOYSÉS, 1977, p. 44). Nessa mesma obra Moysés reafirma a ideia de que o conhecimento além de ampliar a consciência, modifica o próprio modo de pensar e que há certos conhecimentos que desenvolvem mais do que outros algumas funções cognitivas, ditas superiores, como aquelas que permitem uma passagem do concreto para o abstrato. Os métodos que favorecem o desenvolvimento mental do(a) estudante são os que o(a) levam a pensar e o(a) desafia a ir adiante. São também, aqueles que direcionam um processo por meio de ações externas partilhadas socialmente, que serão transformadas em ações mentais. Para Vigotski (2007, p. 87):

[...] a relação entre aprendizado e desenvolvimento permanece, do ponto de vista metodológico, obscura, uma vez que pesquisas concretas sobre o problema dessa relação fundamental incorporaram postulados, premissas e soluções exóticas, teoricamente vagos, não avaliados criticamente e, algumas vezes, internamente contraditórios: disso resultou, obviamente, uma série de erros.

Corroborando com esse pensamento, segundo a visão apresentada nessa obra ${ }^{4}$, as concepções da relação entre desenvolvimento e aprendizagem partem de três posições teóricas (ibidem):

- Os processos de desenvolvimento da criança são independentes do aprendizado, processo externo. Deduzir, compreender, dominar formas lógicas de pensamento e formas abstratas não tem qualquer influência do aprendizado escolar. Aqui não vale os conhecimentos prévios. O desenvolvimento é pré-requisito para o aprendizado (BINET, apud, idem). Dessa forma se as funções mentais de uma criança/estudante não amadurecem o aprendizado não se torna plausível. Segundo essa concepção, a idade

\footnotetext{
3 Original de 1959.

4 Formação Social da Mente.
} 
determina o tipo de aprendizado possível e o desenvolvimento é uma pré-condição para o aprendizado. Resumindo: "o aprendizado forma uma superestrutura sobre o desenvolvimento, deixando este último essencialmente inalterado" (VIGOTSKI, 2007, p. 89).

- Aprendizado é desenvolvimento. O processo de aprendizado se mistura ao processo de desenvolvimento. Para James ${ }^{5}$ (Ibidem), o processo do aprendizado se dá pela formação de hábitos.

As ideias apresentadas divergem em seus pressupostos no que diz respeito às relações temporais entre processo de aprendizado e de desenvolvimento. Para alguns teóricos os ciclos de desenvolvimento precedem os de aprendizado; a maturação é anterior ao aprendizado e a instrução segue o crescimento mental. Em relação à segunda ideia, para outros teóricos, os dois processos são simultâneos.

- A terceira posição tenta ir além e superar os extremos apresentados pelas outras duas, combinando-as. Segundo a teoria de Koffka ${ }^{6}$ (ibidem, p. 90) o desenvolvimento se baseia em dois processos diferenciados, porém relacionados entre si, onde um influencia o outro: a maturação (depende do desenvolvimento do sistema nervoso) e o aprendizado (também um processo de desenvolvimento). Ainda segundo Koffka (idem, ibidem, p. 90-91): "o processo de maturação prepara e torna possível um processo específico de aprendizado. O processo de aprendizado, então, estimula e empurra para frente o processo de maturação".

Dentre importantes pensadores que contribuíram também nos estudos da aprendizagem, o que Vigotski defendia indica uma aproximação com os estudos teóricos e práticos dessa pesquisa em relação aos estudantes com necessidades especiais à medida que se parte do pressuposto que todos, igualmente, são capazes de aprender, desde que lhes sejam fornecidos os elementos necessários para impulsionar novas aquisições, sem que, para isso, seja necessária a maturação prévia, mencionada anteriormente.

\footnotetext{
5 JAMES, William. Talks to Teachers, Nova York, Norton, 1958, p. 36-7.

${ }^{6}$ Koffta, Growth of the Mind.
} 


\subsection{Zona de Desenvolvimento Proximal}

O conceito de zona de desenvolvimento proximal surgiu do interesse de Vigotski em compreender as leis do desenvolvimento e do processo ensino-aprendizagem (VALSINER E VAN DER VEER, 1991, apud, MOYSÉS, 1997). De acordo com os autores citados esse conceito foi se modelando em três contextos diferentes. O primeiro está relacionado à zona de desenvolvimento proximal como a diferença entre uma tarefa desempenhada pela criança sozinha e a realizada com ajuda de um adulto ou um colega. O segundo contexto se dá pela preocupação com o ensino/aprendizagem, sem enfatizar a questão quantitativa que está presente na abordagem anterior. Por fim, o terceiro contexto está ligado ao jogo. Assim, como a autora destaca, o segundo contexto, explicitado anteriormente, é particularmente importante o enfoque nessa questão, dada à característica e objetivos da presente pesquisa. Moysés (1997) destaca nos estudos de Vigotski e seus seguidores, o que se observa até hoje nas escolas: espera-se que as crianças estejam "prontas”. É fácil identificar nas escolas essa postura diante de discursos e ações de professores(as) ao esperar, por exemplo, que o(a) estudante na $5^{\text {a }}$ série $/ 6^{\circ}$ ano já domine, em matemática, as quatro operações fundamentais sem nenhuma responsabilidade em ajudá-los a superar tais dificuldades que ainda são identificadas.

Continuando as investigações de Vigotski junto aos seus colaboradores, concluiu-se, que a criança pode ser capaz de aprender com auxílio de outra pessoa (adulto ou colega "mais adiantado") através de perguntas, exemplos, demonstrações não no sentido de imitar, mas de experimentar de forma construtiva. Vigotski propõe numa situação de ensino-aprendizagem: “O bom ensino é aquele que se adianta ao desenvolvimento" (VYGOTSKY et al. 1988, p. 114; VYGOTSKY 1984, p. 101, apud MYSÉS, 1997, p. 34). Ao trabalhar a zona de desenvolvimento proximal, o(a) professor(a) dá condições para o aparecimento de outras funções, ainda não, ou parcialmente desenvolvidas.

Para os estudiosos de Vigotski, dentre eles Lopes e Morillas (2007), as crianças podem, além da capacidade, no coletivo ou sob determinadas orientações, imitar muitas coisas. Tão importante esse fato que modifica tudo que se pensa da relação existente entre aprendizado e desenvolvimento - uma delas está relacionada aos testes diagnósticos. Antigamente, acreditava-se que esses testes eram tão seguros a ponto de determinar o nível mental e estabelecer os limites do que se podia alcançar em termos de aprendizagem. Tempos depois, esse erro foi percebido no ensino de crianças com 
retardo mental ${ }^{7}$. Esses estudos acreditavam na premissa de que as crianças com disfunção intelectual, não possuíam pensamento abstrato concluindo que o ensino deveria basear-se em métodos puramente concretos, o que de fato não resultou em experiências bem-sucedidas. Procedimentos falhos em ajudá-las e que reforça a deficiência, suprimindo da sua vida acadêmica a oportunidade de superar essa dificuldade, que pode ser permanente ou não (assim quero acreditar partindo já de experiências e observações com estudantes com deficiência intelectual). Assim os(as) estudantes que apresentam essa característica, se deixados(as) a sua própria sorte, "nunca atingirão formas bem elaboradas de pensamento abstrato"(idem). A escola, enquanto abrigar o espaço do desenvolvimento e do conhecimento, deve mobilizar esforços no sentido de possibilitar o avanço desses(as) estudantes. O concreto, dessa forma, passa a ser um meio e não um fim para o desenvolvimento do seu pensamento.

Das idéias mencionadas acrescenta-se que o aspecto fundamental do aprendizado é criar a zona de desenvolvimento proximal. Portanto:

\begin{abstract}
"O aprendizado desperta vários processos internos de desenvolvimento, que são capazes de operar somente quando a criança interage com pessoas em seu ambiente e quando em cooperação com seus companheiros. Uma vez internalizados, esses processos tornam-se parte das aquisições do desenvolvimento independente da criança”. (ibidem, p. 103)
\end{abstract}

A partir da leitura de Vigotski e seus seguidores, considerando, ainda, as experiências vivenciadas em Sala de Recursos bem como no ensino regular, é possível acreditar cada vez mais na ideia de que mesmo que os estudantes que apresentam necessidades especiais, não estão impedidos de aprender como os outros:

[...] embora o aprendizado esteja diretamente relacionado ao curso do desenvolvimento da criança, os dois nunca são realizados em igual medida ou em paralelo. $\mathrm{O}$ desenvolvimento nas crianças nunca acompanha $\mathrm{O}$ aprendizado escolar da mesma maneira como uma sombra acompanha o objeto que o projeta. Na realidade existem relações dinâmicas altamente complexas entre processos de desenvolvimento e de aprendizado, as quais não podem ser englobadas por uma formulação hipotética imutável (grifo nosso) (VIGOTSKI 2007, p. 104).

\footnotetext{
${ }^{7}$ Termo utilizado no texto, porém já em desuso. Trata da deficiência intelectual.
} 


\subsection{O papel das interações na aprendizagem}

Além da relevância em estudar e pesquisar sobre a zona de desenvolvimento proximal, bem como as relações entre aprendizagem e desenvolvimento, Vigotski também contribuiu ao ressaltar a importância da interação social no desenvolvimento de funções mentais superiores. Moysés (2007) ao tratar do assunto, faz referência à interação como objeto de estudo da psicologia (socialização e emoção em grupos). Já no campo da pedagogia há maior preocupação com problemas de ajustamento mais do que de natureza cognitiva. Para além de Vigotski, pesquisadores ao explorarem seus conceitos foram mais longe ao envolver os estudos de atividade compartilhada para a situação de ensino-aprendizagem ${ }^{8}$.

Martins (1997) reafirma a ideia de Vigotski sobre a importância do papel das interações no aprendizado, quando menciona que a criança não se apropria sozinha nem qualitativa, nem quantitativamente, dos conhecimentos que alcança por meio de interações com pessoas mais experientes do grupo social ao qual está inserido. Ao confrontar as ideias e concepções do seu próprio mundo com os do seu grupo levará a uma apropriação de significados diferentes, numa relação dialógica, constituindo sentidos a serem negociados. Para Vigotski, segundo Martins (idem), há distinção entre significado e sentido, onde o signo pode ser compreendido como aquilo que é constituído pelo social e o sentido, como o que é interpretado pelo sujeito histórico, considerando espaço, tempo e contexto de vida tanto pessoal quanto social. Compreenderemos melhor essa ideia ao visualizar o espaço escolar, numa sala de aula independente do conteúdo ou disciplina - pode-se perceber essa interação ao valorizar as trocas entre os pares. Assim:

\footnotetext{
A interação de membros mais experientes com menos experientes de uma dada cultura é parte essencial da abordagem vygotskiana, especialmente quando vinculada ao conceito de internalização: é ao longo do processo interativo que as crianças aprendem como abordar e resolver problemas variados. É por meio do processo de internalização que as crianças começam a desempenhar suas atividades sob a orientação e guia de outros e, paulatinamente, aprendem a resolvê-las de forma independente (MARTINS, 1997, p. 116).
}

\footnotetext{
${ }^{8}$ Essa ideia foi transposta para a pedagogia por Davidov e Elkonin.
} 
O pensamento é uma ação construtiva, dialógica (consigo mesmo e com o outro), permite a interação de todos independentemente de suas condições físicas, psicológicas, cognitivas e história de vida. Os aspectos sociais e culturais são elementos importantes na construção do conhecimento. Pensando em educar para e na diversidade, numa perspectiva inclusiva:

“[...] o homem se constitui enquanto tal no confronto com as diferenças; e um dos laboratórios privilegiados para isso é a escola, onde somos reunidos com diferentes realidades e, no conjunto de tantas vozes, acabamos por acordar significados para determinadas coisas que na individualidade de cada um podem ter diversos sentidos (ibidem, p. 118).

Deste modo, o desenvolvimento do ser humano depende de seu aprendizado em um determinado grupo social e cultural, por meio de interações com outras pessoas (REGO, 2009): [...] “o aprendizado pressupõe uma natureza social específica e um processo através do qual as crianças penetram na vida intelectual daqueles que as cercam” (VYGOTSKY, 1984, p. 99, apud, REGO, 2009, p. 71).

Rego (2009) acrescenta ainda que as interações propostas por Vigotski, passam a ser essenciais na produção de conhecimento dos(as) estudantes, pois elas permitem o diálogo, a cooperação, a troca de informações e o confronto de opiniões. Para uma compreensão melhor da ideia de Vigotski (2010) sobre interações que complementa o que foi dito até aqui, é importante entender o que acontece com a criança desde o seu nascimento, segundo seus estudos. A partir do seu nascimento a criança já se encontra em constante interação com os adultos que a incorporam à sua cultura. Inicialmente, suas respostas se dão por meio de seus processos naturais, sua herança biológica. Com a constante mediação dos adultos, processos psicológicos mais complexos se formam gradativamente, processos interpsíquicos. À medida que elas crescem esses processos, que eram partilhados, passam a ser executados em seu interior, tornando-se intrapsíquico.

Partindo das premissas teóricas até o momento apresentadas, fundamentais para este estudo empírico, serão apresentados a seguir aspectos relacionados especificamente à educação especial. 


\section{2 - A EDUCAÇÃO ESPECIAL NO BRASIL}

Por muito tempo as pessoas com alguma deficiência eram tidas como doentes e assim, necessitavam apenas de cuidados na saúde, seja ela física ou psicológica. Uma mudança de paradigma alterou toda a estrutura social e educacional ao implantar um sistema inclusivo de educação dando a todos(as) o direito de frequentar as escolas regulares garantido e regulamentado em leis. A Declaração Mundial de Educação para Todos (1990), a Declaração Mundial de Salamanca (1994), impulsionaram esse movimento, e a deficiência deixou de ser o foco principal, tendo como elementos importantes o potencial e capacidade do indivíduo, cada vez mais incluído no meio social.

Em se tratando de Legislação destacam-se (GDF, 2010):

Em nível Internacional

- Declaração universal dos Direitos Humanos, 1948: garante educação para todos, sem qualquer distinção racial, social ou econômica;

- Declaração de Jomtien, 09 de março de 1990;

- Convenção da Guatemala, 28 de maio de 1999: pessoas com deficiência possuem os mesmo direitos humanos e liberdade que os demais indivíduos, se constituindo em discriminação, qualquer ação que anule esses direitos;

- Declaração Mundial de Montreal sobre Inclusão, 05 de junho de 2001;

- Convenção da ONU, 2006: estabelece que os Estados participantes devem assegurar educação inclusiva em todas as etapas e modalidades de ensino.

E nível Federal

- Constituição da República Federativa do Brasil, 1988: "Dispõe, dentre outros assuntos, que o dever do Estado com a Educação será efetivado mediante a garantia de atendimento educacional especializado aos portadores de deficiência, preferencialmente na rede regular de ensino (ibid., p. 19);

- Lei no 7.853, 24 de outubro de 1989: Integração da Pessoa Portadora com Deficiência;

- Lei no 8.069, de 16 de junho de 1990: Estatuto da Criança e adolescente; 
- Lei no 9.394, 20 de dezembro de 1996: LDB;

- Lei $\mathbf{n}^{\mathbf{0}}$ 10.098, 19 de dezembro de 2000: normas e critérios para a promoção da acessibilidade;

- Decreto $\mathbf{n}^{\mathbf{0}}$ 3.956, 08 de outubro de 2001: é promulgada a Convenção Interamericana para a Eliminação de Todas as Formas de Discriminação em relação às Pessoas Portadoras de Deficiência;

- Resolução CNE/CEB no 2, 11 de novembro de 2001: estabelece as Diretrizes Curriculares Nacionais para a Educação Especial;

- Lei no 10.436, 24 de abril de 2002: dispõe sobre a LIBRAS (língua Brasileira de Sinais);

- Portaria no 2.678, 2002: diretriz e normas para uso, ensino, produção e difusão do Braille;

- Decreto no 5.154, 2004: recomenda que a Educação de Jovens e Adultos e Educação Profissional sejam desenvolvidas simultaneamente em nível de formação inicial e continuada;

- Decreto no 5.626, 22 de dezembro de 2005: regulamenta a Lei 10.436 de 2002 e o Art. 10.098, de 2000;

- Decreto no 6.094, 24 de abril de 2007: implementação de Planos de Metas. Estabelece a garantia de acesso e permanência no ensino regular e o atendimento às necessidades educacionais especiais dos(as) estudantes(s), com objetivo de fortalecimento da inclusão nas instituições de educação pública;

- Decreto no 186, 09 de julho de 2008: Aprova o texto da Convenção da ONU;

- Decreto $\mathbf{n}^{\mathbf{0}}$ 6.571, 2008: estudantes da educação especial serão contabilizados duplamente no FUNDEB, quando estiverem matriculados em classe regular e no AEE (atendimento educacional especializado), pelo registro no Censo Escolar (MEC/INEP) do ano anterior;

- Resolução no 4 CNE/CEB, 02 de outubro de 2009: estabelece Diretrizes Operacionais para o Atendimento Educacional Especializado na Educação Básica, sob a modalidade Educação Especial;

- Parecer $\mathbf{n}^{\mathbf{0}}$ 711, 1987: Conselho Federal de Educação estabelece ações para o atendimento ao superdotado; 
- Parecer CNE/CEB no 13, 2009: estabelece Diretrizes Operacionais para o Atendimento Educacional Especializado (AEE) na Educação Básica, modalidade Educação Especial.

\subsection{Uma passagem histórica9}

Temos no Brasil alguns marcos importantes contribuindo para a transformação da educação brasileira, culminando em mudanças significativas na perspectiva de uma educação para todos, independente de suas características físicas, mentais, psicológicas. Entre avanços e retrocessos essas mudanças proporcionaram à escola, paulatinamente, a oportunidade de conviver com a diversidade.

Desde 1854 o Brasil já acenava para um trabalho de valorização das pessoas com deficiência. Isso aconteceu quando D. Pedro II fundou o Imperial Instituto dos Meninos Cegos, sem preocupação com a aprendizagem. Cem anos depois é fundada a primeira Associação de Pais e Amigos dos Excepcionais (APAE), surgindo o ensino especial como opção à escola regular. Em 1961 é promulgada a Lei de Diretrizes e Bases da Educação Nacional, onde está garantido o direito da criança com deficiência à Educação. O ano de 1971 guarda a marca de um retrocesso jurídico ao ser criada a Lei $\mathrm{n}^{\mathrm{o}} 5.692$ que determina "tratamento especial" para a criança com deficiência, reforçando as escolas especiais. O Centro Nacional de Educação Especial (CENESP) é criado em 1973 com o objetivo de integrar as crianças que conseguem acompanhar o ritmo, indo os demais para a escola especial. Cria-se aí uma segregação. A Constituição Federal de 1988 estabelece a igualdade de acesso à escola, obrigando o Estado a dar atendimento especializado, preferencialmente na rede regular. Cerca de um ano depois é aprovada a Lei $n^{\circ} 7.853$, que criminaliza o preconceito, só foi regulamentada dez anos depois.

Prosseguindo a linha do tempo, em 1990 o Estatuto da Criança e do Adolescente dá a pais e responsáveis a obrigação de matricular os filhos na rede regular de ensino. Concomitantemente a Declaração Mundial de Educação para Todos reforça a Declaração Mundial dos Direitos Humanos e estabelece que todos devem ter acesso à Educação. Em 1994, a partir da Declaração de Salamanca que define políticas, princípios e práticas da Educação Especial e influi nas políticas da Educação, a política

\footnotetext{
${ }^{9}$ Informações extraídas da Revistas Nova Escola, Edição Especial: Inclusão - como ensinar os conteúdos do currículo para alunos com deficiência, 2009.
} 
Nacional de Educação Especial condiciona o acesso ao ensino regular àqueles que possuem condições especiais de acompanhar "os ditos normais". Em 1996, na teoria, a LDB atribui às redes o dever de assegurar currículo, métodos, recursos e organização para atender às necessidades dos alunos; há quase 15 anos atrás a lei já garantia as adequações visando atender as especificidades de cada estudante e só agora se tem encaminhado essas questões na escola - fator desconhecido ainda para muitos(as) professores(as). O Decreto 3.298, de 1999, cria a Coordenadoria Nacional para Integração da Pessoa Portadora de Deficiência, definindo a Educação Especial como ensino complementar.

Em uma nova década as redes se abrem. A Resolução CNE/CEB 2, em 2001, divulga a criminalização da recusa em matricular crianças com deficiência e o quantitativo delas frequentando o ensino regular aumenta. Nesse mesmo ano o Brasil promulga a Convenção de Guatemala, que define como discriminação, com base na deficiência, o que impede o exercício dos direitos humanos. A partir daí é preciso pensar na formação docente. Em 2002, a Resolução CNE/CP 1 define que a universidade deve formar professores para atender alunos(as) com necessidades especiais. Nesse mesmo ano a LIBRAS (língua brasileira de sinais), através da Lei $\mathrm{n}^{\mathrm{o}}$ 10.436/02, é reconhecida como meio legal de comunicação e expressão. Ainda em 2002, a Portaria 2.678 aprova norma para o uso, ensino, produção e difusão do Braile em todas as modalidades de educação. Em 2003 o MEC cria o Programa Educação Inclusiva: Direito à diversidade, que forma professores para atuar na disseminação da Educação Inclusiva. A inclusão se difunde. O ministério Público Federal, em 2004, reafirma o direito à escolarização de alunos com e sem deficiência no ensino regular. A convenção aprovada pela Organização das Nações Unidas, em 2006, estabelece que as pessoas com deficiência tenham acesso ao ensino inclusivo. É dado mais um passo para o fim da segregação.

Ao nos aproximarmos de 2011, contamos com o fim da segregação. Em 2008, A Política Nacional de Educação Especial na Perspectiva da Educação Inclusiva define que todos devem estudar na escola comum. Pela primeira vez o número de crianças com deficiência matriculadas nas escolas regulares, ultrapassa o das que estão na escola especial. O Brasil ratifica a Convenção dos Direitos das Pessoas com Deficiência, da ONU, fazendo da norma parte da Legislação Nacional.

Sem anseio de transformar esse capítulo em conclusão, mas dada a necessidade de fazer uma pequena pausa para reflexão diante da retrospectiva sobre a história da 
Educação Especial no Brasil, em atenção às informações consideradas; ponderar-se-á um pouco mais a respeito da grande revolução e evolução do ensino voltado para as pessoas com necessidades especiais.

Após essas discussões teóricas pretende-se aqui dialogar com a história e abrir um espaço para algumas ponderações, ainda que reflitam uma visão pessoal. Em tempos de escola, não houve oportunidade de conviver com pessoas deficientes. Pouco se falava a respeito e as informações que chegavam vinham dos meios de comunicação divulgando as ações que eram realizadas pelas instituições que cuidavam do assunto. Ao longo de mais de um século pode-se perceber o quanto nossa sociedade está diferente. Não só pelas conquistas tecnológicas, avanços da medicina, emancipação feminina, mas também pela grande oportunidade que essas conquistas legais permitiram à sociedade conviver com uma parcela de cidadãos significativamente excluídos, até então. Destacase ainda, o ano de 2008 quando apresenta um dado importante dessa evolução: primeira vez que a quantidade de estudantes com necessidades especiais das escolas regulares ultrapassa o número nas escolas especiais. Foi um avanço. Com a criação do Programa Educação Inclusiva, criado pelo MEC, conquistou-se também o Direito à Diversidade (que vai além da convivência com pessoas com deficiência). A sociedade já faz um caminho diferente ao incluir, através de leis e debates, ações que minimizem as dificuldades e barreiras que ainda são encontradas por quem tem alguma necessidade especial. Mas nem tudo, nesse caminho histórico real, é tão positivo. Há muitos obstáculos a serem eliminados, principalmente pré-conceitos. Muitos, inclusive, estão ligados as próprias dificuldades enfrentadas pelos(as) profissionais da educação.

\subsection{Inclusão escolar: novos desafios}

Ao tratar a inclusão pode-se incorrer no erro de tratar as diferenças como se elas fossem algo a modificar. "[...] a inclusão propõe a desigualdade de tratamento como forma de restituir uma igualdade que foi rompida por formas segregadoras de ensino especial e regular" (Mantoan, 2006, p. 16).

Ainda, segundo Mantoan, 2006, não se pode estabelecer a igualdade em tudo. Bobbio (1997, p. 25, apud ibidem, p.17) menciona que Rousseau, em Discurso sobre a origem da desigualdade entre homens, trata da diferença existente entre as desigualdades naturais e sociais. Àquelas, de caráter natural, não podem ser modificadas por se tratar de natureza, inerente ao ser, é a sua individualidade. Esta trata das relações 
de poder, de domínio econômico, social, político, espiritual. A última deve ser eliminada no sentido de estabelecer os ideais de igualdade que sempre foram o marco de tantas lutas e resistências na História - no mundo e no Brasil:

[...] não é a universalidade da espécie que define um sujeito, mas as suas peculiaridades, ligadas ao sexo, etnia, origem, crenças, tratar as pessoas diferentemente pode enfatizar suas diferenças, assim como tratar igualmente os diferentes pode esconder as suas especificidades e excluí-los do mesmo modo; portanto, ser gente é correr sempre o risco de ser diferente (idem).

Ao defender o respeito à particularidade do indivíduo, nessa mesma obra Mantoan menciona a perversidade da instituição educacional que mesmo garantindo acesso e permanência das pessoas com deficiência ou com outros problemas (que impendem seu sucesso acadêmico), não garante a permanência e a continuidade da escolarização. Dessa forma, o modelo educacional que temos continua elitista e faz-se imperioso romper com essas bases, pois, mesmo que as leis assegurem ensino e escola para todos, vive-se várias contradições que mostram a fragilidade do sistema inclusivo que tanto permeia os discursos políticos e sociais. É preciso "reconhecer a igualdade de aprender como ponto de partida e as diferenças no aprendizado como processo e ponto de chegada" (idem).

Em se tratando de igualdade, segundo Joseph Jacotot (apud, ibidem), acreditava na igualdade de inteligências, que não pode se submeter à outra. Para ele, emancipar a inteligência se faz a partir da igualdade na capacidade de aprender, como ponto de partida, em qualquer nível de aprendizagem ou escolarização. O que se faz na escola está na contramão quando "se obrigam" todos a aprender tudo, no tempo que se determina. Enquanto isso acontecer a escola continua sendo um espaço de "discriminação de inteligências".

\subsection{A Sala de Recursos e atribuições do professor no contexto do Distrito Federal}

As Salas de Recursos presentes na maioria das escolas da Rede Pública de Ensino de Brasília são um Espaço Pedagógico voltado para o atendimento educacional especializado. Está definido nas Diretrizes Curriculares Nacionais para a Educação Especial na Educação Básica (CNE/CEB, 2001), onde as escolas regulares devem 
prever e prover na organização de suas classes comuns serviço de apoio especializado, onde o professor especializado em educação especial complementa ${ }^{10} \mathrm{e} / \mathrm{ou}$ suplementa ${ }^{11}$ as orientações curriculares que são próprias das classes comuns, utilizando equipamentos, recursos e materiais específicos. Deverá acontecer em todas as etapas e modalidades da Educação Básica (GDF, 2010).

Segundo as Diretrizes da Política Nacional de Educação Especial na Perspectiva da Educação Inclusiva temos que:

O Atendimento Educacional Especializado tem como função identificar, elaborar e organizar recursos pedagógicos e de acessibilidade que eliminem as barreiras para a plena participação dos alunos, considerando suas necessidades específicas. As atividades desenvolvidas no atendimento educacional especializado diferenciam-se daquelas realizadas na sala de aula comum, não sendo substitutivas à escolarização (MEC, 2008, apud GDF, 2010, p. 77).

De acordo com o último Censo Escolar, a educação de alunos que possuem necessidades educacionais especiais já se efetiva nos espaços de sala de aula regular. De cada 10 alunos, 6 já estão matriculados em classes comuns. O índice em 2001 era de apenas 2 em cada 10. Seguindo a estatística divulgada pelo Censo Escolar, 27\% dos alunos matriculados, atualmente, no ensino regular recebem apoio das Salas de Recursos, com ampliação prevista para mais de 50\%, considerando a implantação de novas salas (Nova Escola, 2009).

O serviço realizado pelas Salas de Recursos visa apoiar o desenvolvimento dos (das) estudantes inseridos(as) em classes comuns do ensino regular. Preferencialmente deve acontecer no contraturno e na própria instituição educacional em que se encontram matriculados(as), embora, dependendo da situação, existam alguns atendimentos realizados no mesmo horário da aula regular.

O foco do trabalho nas Salas de Recursos é a prática pedagógica, ainda que muitos vejam esse ambiente como um espaço para "reforço escolar". As atividades são variadas e visam atender necessidades específicas. Para os deficientes visuais o apoio é na utilização do Braile, os deficientes auditivos estudam Libras, com o auxílio de um intérprete. As demais deficiências, previstas em lei, se apóiam em jogos e outros

\footnotetext{
${ }^{10}$ Para estudantes com deficiência e TGD.

${ }^{11}$ Para estudantes com altas habilidades/superdotação.
} 
recursos, de acordo com as particularidades de cada uma, onde é realizado um plano de ação pedagógica que os(as) auxiliará tanto na vida escolar da classe comum quanto na sua vida diária. As ações pedagógicas previstas para cada estudante que frequenta regularmente a Sala de Recursos devem ser definidas em parceria com o(a) professor(a) regente.

Segundo documentos que regem as atividades realizadas pelas Salas de Recursos (GDF, 2010), temos:

- Programas de enriquecimento curricular;

- Ensino de linguagens e códigos específicos de comunicação e sinalização e tecnologia assistiva, que devem estar articulados com a proposta pedagógica do ensino regular;

- Apoio, assistência e orientação ao professor de sala regular no que diz respeito às avaliações, adequações curriculares ou qualquer outra necessidade que atenda às especificidades de cada estudante;

- Orientação e apoio à família de forma a facilitar o acompanhamento do estudante tanto nas atividades curriculares quantos nas atividades de vida diária de forma a torná-lo cada vez mais autônomo.

Existem na Secretaria de Estado de Educação do Distrito Federal (SEE/DF) dois tipos de Salas de Recursos: Generalistas e Específicas. Na primeira, estudantes com deficiência intelectual, transtornos globais do desenvolvimento, deficiência física, deficiência múltipla têm atendimento individualizado ou em grupo. Na segunda, os atendimentos são específicos e englobam três modelos: sala de recursos para deficiente auditivo, deficiente visual e altas habilidades/superdotação.

Na maioria das instituições onde esse atendimento é ofertado há dois professores especializados. Existem atribuições específicas para cada tipo de Sala de Recursos, que visa garantir o bom atendimento dos(as) estudantes que precisam frequentá-las. Nas próximas seções deste texto apresentaremos as atribuições dos profissionais que atuam em Sala de Recursos. 
2.3.1. Atribuições ${ }^{12}$ de todos(as) os(as) profissionais que atuam em Sala de Recursos

- Atuar como docente nas atividades de complementação/suplementação curricular específica.

- Atuar de forma colaborativa com o professor de classe comum para a definição de estratégias pedagógicas que favoreçam o acesso do estudante com deficiência, $\mathrm{TGD}^{13}$, altas habilidades/superdotação ao currículo e a sua interação com o grupo;

- Promover as condições de inclusão desses(as) estudantes(as) em todas as atividades da instituição educacional;

- Informar à comunidade escolar acerca da legislação e das normas educacionais vigentes que asseguram a inclusão educacional;

- Participar do processo de identificação e de avaliação pedagógica das necessidades especiais, e tomadas de decisões quanto ao apoio especializado necessário para o(a) estudante;

- Preparar material específico para o uso dos(as) estudantes na sala comum e na sala de recursos;

- Orientar a elaboração de material didático-pedagógico que possa ser utilizado pelos(as) estudantes nas classes comuns do ensino regular;

- Indicar e orientar o uso de equipamentos e de materiais específicos, bem como de outros recursos existentes na família e na comunidade e articular, com gestores e com professores(as), para que a proposta pedagógica da instituição educacional seja organizada coletivamente em prol de uma educação inclusiva;

\footnotetext{
${ }^{12}$ Caderno de Orientação Pedagógica - Educação Especial. SEEDF, Brasília, DF, 2010, p 78.

${ }^{13}$ Transtornos Globais do Desenvolvimento.
} 
- Responsabilizar-se junto aos docentes pela garantia da realização das adequações curriculares necessárias ao processo educacional do(a) estudante com necessidade educacional especial;

- Realizar atividades que estimulem o desenvolvimento dos processos mentais: atenção, percepção, memória, raciocínio, imaginação, criatividade, linguagem, dentre outros;

- Fortalecer a autonomia dos(as) estudantes a fim de levá-los a ter condições de decidir, opinar, escolher tomar iniciativas, a partir de suas necessidades e motivações;

- Propiciar a interação dos(as) estudantes em ambientes sociais, valorizando as diferenças e a não discriminação;

- Preparar materiais e atividades específicas para o desenvolvimento da aprendizagem dos(as) estudantes;

- Orientar o(a) professor(a) da classe comum sobre estratégias que favoreçam a autonomia e o envolvimento do estudante em todas as atividades propostas ao grupo;

- Promover a inserção dos recursos tecnológicos de informação e de comunicação no espaço da sala de aula;

- Realizar adequações de material didático-pedagógico para atender as necessidades dos(as) estudantes;

- Reconhecer os pontos fortes e de maior interesse e as dificuldades do(a) estudante; e

- Ofertar suporte pedagógico aos estudantes, facilitando-lhes o acesso aos conteúdos desenvolvidos em classe comum e turmas de integração inversa. 
2.3.2. Atribuições ${ }^{14}$ dos(as) docentes das Salas de Recursos Generalistas

- Proporcionar ao(à) estudante conhecimento de seu corpo, levando-o a usá-lo como instrumento de expressão consciente, na busca de sua independência e na satisfação de suas necessidades;

- Mediar ações junto ao profissional de Educação Física do Centro de Ensino Especial para orientar o(a) professor(a) regente quanto às atividades que devem ser desenvolvidas no aspecto motor;

- Operacionalizar as complementações curriculares específicas necessárias à educação dos(as) estudantes com deficiência física, no que se refere ao manejo de materiais adaptados e à escrita alternativa, quando necessário; às vivências de mobilidade e de acesso aos espaços da instituição educacional e às atividades da vida diária que envolvam a rotina escolar, dentre outras;

- Mediar ações junto ao profissional de área médica para orientar os(as) estudantes para a adaptação ao uso de prótese de membro superior ou inferior;

- Introduzir o(a) estudante no aprendizado da informática acessível, identificando melhor recurso da tecnologia assistiva que atenda às suas necessidades, considerando a sua habilidade física e sensorial atual, bem como capacitá-lo para o uso independente do computador;

- Garantir o suprimento de material específico de comunicação aumentativa e alternativa (pranchas, cartões de comunicação, vocalizadores, dentre outros, que atenda à necessidade comunicativa do estudante no espaço escolar;

- Adaptar material pedagógico (jogos, livros de histórias) com a simbologia gráfica e construir pranchas de comunicação temáticas para cada atividade, com o objetivo de proporcionar a apropriação e o aprendizado

\footnotetext{
${ }^{14}$ Ibidem, 2010, p.80.
} 
do uso do recurso de comunicação e a ampliação de vocabulário de símbolos gráficos;

- Identificar o melhor recurso de tecnologia assistiva que atenda às necessidades dos(as) estudantes, de acordo com sua habilidade física e sensorial atual e que, promova sua aprendizagem por meio da informática acessível;

- Habilitar os(as) estudantes para o uso de "softwares" específicos de comunicação aumentativa e alternativa, utilizando o computador como ferramenta de voz, a fim de lhes proporcionar expressão comunicativa;

- Ampliar o repertório comunicativo do(a) estudante, por meio de atividades curriculares e de vida diária;

- Fundamentar o trabalho na adaptação do ambiente por meio de sua organização, facilitando a compreensão da criança em relação à sala de aula;

- Orientar os(as) professores regentes para organizar contexto educativo que favoreça a atenção e a concentração dos estudantes nas atividades desenvolvidas em sala de aula, observando os seguintes cuidados: sentálos na primeira fila, falar seu nome várias vezes durante a aula e verificar seus cadernos para certificar-se de que estão executando as tarefas;

- Organizar os materiais que serão utilizados, para que o(a) estudante compreenda o que necessita fazer;

- Organizar uma rotina diária previsível e adequada para cada estudante;

- Identificar a Sala de Recursos de modo que o(a) estudante possa se dirigir sozinho ao local de atendimento;

- Começar com tarefas curtas e utilizar-se de pouco material, para, gradativamente, proceder no aumento de sua complexidade, de modo a proporcionar a necessária segurança emocional;

Atualmente, no Distrito Federal, das 630 escolas, 496 têm salas especializadas que atendem estudantes com necessidades educacionais especiais (informação verbal) ${ }^{15}$ sob a responsabilidade de professores(as) capacitados(as) e especializados(as), que

\footnotetext{
${ }^{15}$ Disponibilizada pela Diretoria de Educação Especial da SEE/DF, 2011.
} 
segundo a Resolução CNE/CEB $n^{\circ}$ 2, são aqueles que desenvolveram competências para definir, implementar, apoiar as estratégias que dizem respeito à flexibilização, adequação curricular, procedimentos didático-pedagógicos e qualquer outra ação que viabilize o pleno desenvolvimento do(a) estudante, auxiliando, quando necessário o(a) professor(a) de classe regular nessas ações (GDF, 2010).

Para que o(a) professor(a) esteja apto a desenvolver as atividades que são comuns às Salas de Recursos é necessário que este(a) profissional se submeta à entrevista com a equipe técnica responsável pela Educação Especial na SEE/DF, após apresentação de curso de capacitação na área de inclusão. Importante ressaltar que apenas a apresentação do curso e a aprovação em entrevista não são suficientes para capacitar o(a) profissional. É relevante que participe com frequência de encontros, reuniões e outras capacitações que o prepare cada vez mais para atuar, considerando que seu trabalho não se restringe ao(à) estudante; pois envolve também o trabalho pedagógico da escola junto aos(às) professores(as), equipe gestora, funcionários e comunidade, de forma a promover sua inserção na escola, que refletirá consequentemente, na sociedade:

\footnotetext{
Não é apenas a qualificação profissional do professor, inicial e continuada, fator indicativo de sua competência para atuar com estudantes com necessidades especiais. É imprescindível que ele disponha de qualidades humanas e de desenvolvimento profissional que o capacite para essa atuação (GDF, 2010, p. 59).
}

- Identificar a existência de fatores desencadeantes de problemas de comportamento; e

- Incentivar a comunicação, colocando à sua disposição mecanismos que lhe possibilitem pedir o auxílio que necessitar.

2.4. A concepção curricular na perspectiva da educação inclusiva: adequações curriculares

O currículo tem como função orientar as atividades educacionais, quais são suas finalidades e como executá-las (GDF, 2010). Como o processo educacional é dinâmico, o currículo deve ser atualizado considerando as mudanças, de forma a atender 
as necessidades pedagógicas no meio em que está inserido, a fim de oportunizar o acesso a todos ao conhecimento, levando em conta as particularidades de cada um(a).

Na visão de Mittler, “os desafios pedagógicos relacionam-se à aprendizagem. E, com base na experiência britânica para a atual década, ele defendeu os seguintes princípios para a preparação do trabalho docente:"

- $\quad$ Estabelecer desafios de aprendizagem compatíveis com as condições do estudante;

- Responder à diversidade das necessidades de aprendizagem dos estudantes; e

- Superar barreiras potenciais à aprendizagem e à avaliação tanto do estudante como da turma (MITLER, 2003, p. 145, apud GDF, 2010, p. $37)$.

Dessa forma torna-se imprescindível flexibilizar os conteúdos em respeito à diversidade. Não se pode falar em inclusão sem considerar tempo, trabalho diversificado, utilização de materias/recursos complementares e/ou suplementares que atenda à nova demanda presente nas escolas e propicie apoio àqueles(as) que apresentam uma particularidade para aprender. Assim sendo:

A instituição Educacional é, por excelência, um espaço real de diversidade, no qual a inclusão educacional materializa-se a partir das experiências cotidianas vivenciadas e compartilhadas pela comunidade escolar (GDF, 2010, p. 38).

Nesse novo modelo de escola, falar em "currículo fechado" parece pouco apropriado. Surgem então, como proposta, as adequações curriculares, que visam minimizar as dificuldades encontradas pelos(as) estudantes que apresentam alguma necessidade especial e que favoreçam sua aprendizagem. Assim o currículo regular é tomado como base, norteando o trabalho do(a) professor(a) e adequando-se às reais necessidades do(a) estudante, individualmente. Pelo exposto entende-se que:

As adequações curriculares são compreendidas como medidas pedagógicas que se destinam ao atendimento dos estudantes com necessidades educacionais especiais de modo a favorecer a sua escolarização (GDF, 2010, p.39). 
Segundo a Resolução no 01/2009, o Conselho de Educação do Distrito Federal, em seu artigo 44:

\begin{abstract}
Art. 44 - A estrutura do currículo e da proposta pedagógica, para atender às especificidades dos estudantes com necessidades educacionais especiais deve observar a necessidade de constante revisão e adequação da prática pedagógica nos seguintes aspectos:

I - introdução ou eliminação de conteúdos, considerando a condição individual do estudante;

II - modificação metodológica dos procedimentos, da organização didática e da introdução de métodos;

III - temporalidade com a flexibilização do tempo para realizar as atividades e desenvolvimento de conteúdos;

IV - avaliação e promoção com critérios diferenciados, em consonância com a proposta pedagógica da instituição educacional, respeitada a frequiência obrigatória.
\end{abstract}

Parágrafo único. Os estudantes de classes especiais ou centros especializados devem ser constantemente acompanhados com vistas a sua inclusão no ensino regular (DODF, 2009, p. 5).

Nessa perspectiva, as adequações curriculares tornam-se medidas pedagógicas imprescindíveis na organização da escola, tendo como foco sempre o potencial do(a) estudante.

As adequações curriculares não representam apenas um processo particular e individualizado, embora seja fundamental que o(a) professor(a) conheça as necessidades educacionais especiais do(a) estudante (sem enfatizar a questão clínica) ${ }^{16}$, conhecendo o que ele pensa, sente, como se relaciona com o mundo, com as pessoas, seus pontos fortes, sua história de vida (preferências, habilidades). Elas devem estar garantidas também na proposta pedagógica da escola, no currículo e no plano de trabalho individual do professor com o(a) estudante. A instituição educacional necessita se organizar como um todo. Existe um formulário próprio definido pela unidade central da Educação Especial da SEE/DF ${ }^{17}$, onde devem estar registradas essas decisões de forma a garantir o direito de quem necessita de um trabalho diferenciado, porém, que permita, também, a sua inserção em sala de aula, sem qualquer tipo de discriminação.

\footnotetext{
${ }^{16}$ Ler: A transformação do espaço pedagógico em espaço clínico (a patologização da educação) - anexo I. Há considerações importantes sobre o assunto.

${ }^{17}$ Formulário de adequação curricular utilizado na SEE/DF - anexo II.
} 
Seguindo orientações previstas nas adequações, norteados pelos Parâmetros Curriculares Nacionais, deve-se ter claro o que o(a) estudante deve aprender; como e quando aprender, o processo de aprendizagem que seja mais eficiente; e o que, como e quando avaliar. As adequações não são fechadas em si, possuem caráter processual. Podem e devem ser alteradas sempre que for imprescindível, visando atender da melhor forma possível às necessidades individuas de cada estudante. Classificam-se em adequações de acesso e adequações nos elementos curriculares (GDF, 2011), conforme explicações a seguir:

\subsubsection{Adequações de acesso ao currículo ${ }^{18}$}

Conjunto de modificações físicas e materiais do ensino, e também, nos recursos que o(a) professor(a) utiliza no preparo do seu trabalho pedagógico em sala de aula. São elas:

- $\quad$ criar condições físicas, ambientais e materiais na instituição educacional;

- $\quad$ propiciar um melhor nível de comunicação e interação com as pessoas da escola;

- favorecer a participação nas atividades da escola, propiciando sua inserção;

- empregar mobiliário específico, quando necessário;

- fornecer equipamentos e recursos materiais específicos;

- $\quad$ adaptar materiais de uso em sala de aula;

- utilizar sistema de comunicação alternativo, quando necessário.

Algumas sugestões que favorecem o acesso ao currículo:

- eliminar barreiras atitudinais em toda a comunidade escolar;

- estimular e incentivar as relações interpessoais, promovendo tarefas em grupos, de forma a facilitar a realização das atividades que são propostas;

- encorajar, estimular a participação, a iniciativa;

\footnotetext{
${ }^{18}$ Texto extraído do Currículo de Educação Básica - Educação de Jovens e Adultos, uma adaptação do documento: Parâmetros Curriculares Nacionais - Adequações Curriculares, MEC, 1998.
} 
- observar a luminosidade, sonoridade e movimentação adequados no ambiente;

- adaptar materiais escritos de forma a torná-lo mais acessível à compreensão;

- providenciar adequação de instrumentos de avaliação e de ensino e aprendizagem;

- favorecer a comunicação entre estudantes e demais segmentos da escola.

- equipar a escola com softwares educativos específicos.

As sugestões apresentadas anteriormente visam favorecer os(as) estudantes de forma mais generalizada. Porém, há algumas adequações que são específicas e atendem a determinadas deficiências. Enumera-se aqui algumas sugestões de acesso ao currículo para estudantes com deficiência intelectual - foco da pesquisa (GDF, 2011):

- $\quad$ acolhimento e respeito ao ritmo e estilo de aprendizagem;

- utilização de instruções por meio de sinais claros e simples;

- planejamento de atividades utilizando nível de complexidade crescente;

- $\quad$ maior atenção do(a) professor(a);

- utilização de material concreto;

- $\quad$ espaços pedagógicos diferenciados, favorecedores da aprendizagem;

- desenvolvimento de habilidades adaptativas: sociais, acadêmicas, de comunicação, lazer, saúde, segurança, cuidado pessoal, autonomia;

- diversificação metodológicas, visando adequação à necessidade individual do(a) estudante.

\subsubsection{Adequações nos elementos curriculares}

As adequações nos elementos curriculares:

[...] focalizam as formas de ensinar e de avaliar, bem como os conteúdos a serem ministrados, considerando a temporalidade. São definidas como alterações realizadas nos objetos, nos conteúdos, nos critérios e nos procedimentos de avaliação, nas atividades e nas metodologias para atender às diferenças individuais dos/das estudantes (GDF, 2011). 
Temos então, as seguintes adequações nos elementos curriculares: Adequações metodológicas e didáticas e Adequação dos conteúdos curriculares e do processo avaliativo. Estes dois tipos de adequações são explicados a seguir.

\subsubsection{Adequações metodológicas e didáticas}

São aquelas que dizem respeito a procedimentos técnicos e metodológicos, estratégias de ensino e de aprendizagem, procedimentos avaliativos e atividades programadas para os(as) estudantes. Como exemplo:

- $\quad$ situar o(a) estudante em grupos em que melhor possa trabalhar;

- adotar métodos e técnicas de ensino e de aprendizagem específicas para o(a) estudante;

- utilizar técnicas, procedimentos e instrumentos de avaliação distintos na turma, considerando os objetivos da avaliação e seu conteúdo;

- propiciar apoio físico, visual, verbal, de forma a permitir que o(a) estudante possa realizar as atividades escolares e avaliativas. Apoio este oferecido tanto pelo(a) professor(a) especializado(a), como pelo(a) regente e até mesmo pelos próprios colegas de sala de aula;

- inserir atividades complementares individuais, a fim de que o(a) estudante alcance os objetivos que são comuns ao colegas de classe;

- inserir atividades complementares e/ou suplementares específicas para esse(a) estudante, quer seja individualmente ou em grupo;

- $\quad$ ressignificar atividades que restrinjam a participação do(a) estudante.

2.4.2.2. Adequação dos conteúdos curriculares e do processo avaliativo

Consistem em adequações individuais, considerando objetivos, conteúdos, critérios avaliativos, que responda às necessidades individuais do(a) estudante. São elas:

- adequar objetivos, conteúdos, critérios avaliativos, modificando-os, considerando as particularidades do(a) estudante;

- priorizar objetivos, conteúdos, critérios avaliativos, dando ênfase aos objetivos que foram traçados, considerando as particularidades do(a) 
estudante. Isso não implica em abandono dos objetivos elencados para a turma, mas possibilitar o acréscimo de outros que atendam as necessidades educacionais especiais que lhe caracteriza;

- adequar o tempo (temporalidade) estabelecido quanto aos objetivos, conteúdos, critérios avaliativos, visto que os mesmos podem ser alcançados pelo(a) estudante, porém em tempos diferentes dos demais.

- Adequar à temporalidade dos componentes curriculares. Isso permite que o(a) estudante possa cursar os mesmos componentes curriculares previstos na série, porém em tempo maior. Como, por exemplo, cursar em dois anos o que está previsto em apenas um ano letivo.

- Introduzir conteúdos, objetivos e critérios avaliativos que sejam necessários ao desempenho do(a) estudante;

- Suprimir conteúdos, objetivos e critérios avaliativos. Havendo necessidade dessa "eliminação" considerar os seguintes aspectos:

$\checkmark \quad$ que seja precedida de uma criteriosa avaliação das competências do(a) estudante;

$\checkmark \quad$ que seja analisado o contexto escolar e familiar;

$\checkmark$ que haja participação da equipe institucional e equipe multidisciplinar;

$\checkmark \quad$ que seja documentada todas as medidas adaptativas, fazendo parte do acervo do(a) estudante;

$\checkmark$ que evite prejuízo no desempenho, promoção escolar e socialização do(a) estudante;

$\checkmark \quad$ que sejam adotados critérios que evitem a supressão de conteúdos expressivos (de forma quantitativa e qualitativa).

\subsubsection{Adequações curriculares: uma reflexão importante}

Diante do que foi exposto é importante a reflexão a respeito da forma como a escola foi concebida e está estruturada até hoje. Ainda que a lei garanta flexibilização curricular e modificação do tempo, o processo de inclusão requer também, uma mudança estrutural na concepção de ensino e aprendizagem que se encontra nas escolas atuais: "o processo de inclusão escolar preconiza uma instituição educacional de qualidade para todos(as) e com todos(as) os(as) estudantes" (GDF, 2010). Melhor seria 
que não fosse preciso adequar, mas sim, oportunizar e garantir que todos tenham acesso ao conhecimento. Não são apenas os(as) estudantes tidos como "deficientes" que necessitam de um olhar individualizado. Existem outras questões que estão presentes na escola e que muitas vezes impedem os(as) estudantes de aprenderem. Por isso as adequações constituem em possibilidades de atuar nas várias situações que envolvem as dificuldades de aprendizagem, presentes na escola e que caracterizam outros(as) estudantes.

Nessa nova abordagem a escola "é uma importante agência social promotora do desenvolvimento e da construção do saber” (Kelman 2010, p. 42) e para Vigotski (apud, idem) é o local onde conceitos espontâneos são transformados em conceitos científicos, embora para a mesma autora, a escola além de oferecer seu espaço como um ambiente propício ao desenvolvimento é também local onde se originam uma quantidade grande de violência tanto por parte dos(as) estudantes entre si como dos(as) estudantes em relação aos(as) professores(as). No passado o(a) professor(a) tinha uma autoridade maior sobre os(as) estudantes e hoje enfrenta a dura fragilidade das relações tentando controlar indisciplina. A família, por outro lado, na figura dos pais, enfrenta inúmeras dificuldades em acompanhar sistematicamente seus (suas) filhos(as), em virtude da necessidade de trabalhar (ambos) para mantê-la economicamente.

Nesse contexto, escola e família desempenham novos papéis e a parceria nessa relação torna-se indispensável. É imperioso conhecer o(a) estudante e a família em que este(a) está inserido(a) para pautar as ações necessárias ao sucesso acadêmico de todos, mas especialmente àqueles que enfrentam, pelas suas particularidades, outros desafios de superação que vão além da aprendizagem que é ofertada nos espaços educacionais.

Kelma (2010) estabelece alguns recursos e estratégias que complementam e ratificam a importância de se criar um projeto pedagógico inclusivo. A primeira diz respeito aos conflitos, o segundo está relacionado à organização pedagógica da escola e a criação de estratégias que atenda efetivamente o contexto inclusivo da qual ela faz parte agora. O terceiro é pertinente aos indicadores que devem ser considerados em contextos inclusivos em relação à criança, ao professor e à coletividade.

Dessa forma, tudo que se propõe ao tratar da escola inclusiva, com suas adequações, físicas e de conteúdo exige uma reflexão acerca também dessa nova sociedade que se impõe, pois “a inclusão é constituída como um processo de transformação social” (idem, p. 69). 


\section{3 - O (A) ESTUDANTE COM DEFICIÊNCIA INTELECTUAL NO AMBIENTE ESCOLAR: CONHECENDO E ENTENDENDO SUAS POTENCIALIDADES}

\subsection{Definindo a deficiência intelectual}

No ambiente escolar estamos acostumados a nos deparar com situações e limitações que são visíveis aos nossos olhos e que encontram soluções também observáveis. É fácil perceber quando um individuo é "cego", "surdo”, não pode "andar", "não possui algum membro (inferior ou superior)". Da mesma forma que o identificamos previamente, os recursos e adequações de que necessitam também são disponibilizados com facilidade. Assim o deficiente auditivo faz uso da Língua Brasileira de Sinais, o deficiente visual tem como apoio o Braile e o deficiente físico, se apóia nas adaptações do ambiente e nos materiais que lhe proporcionam certa independência. Geralmente, essas ações já resolvem as dificuldades que eles (elas) enfrentam na escola, que de certa forma não lhes trazem impedimentos para aprender (com algumas exceções) ${ }^{19}$. O que é deficiência intelectual? O que fazer quando se trata de deficiência intelectual na escola? Como identificar um (a) estudante com deficiência intelectual na sala de aula?

A American Association on intellectual and Developmental Disabilities AAIDD, define como deficiência intelectual/mental como a

\footnotetext{
“incapacidade caracterizada por importantes limitações, tanto no funcionamento intelectual como no comportamento adaptativo, expressa nas habilidades adaptativas conceituais, sociais e práticas. Essa capacidade tem início antes dos 18 anos de idade” (AAMR, 2006, p. 20, apud GDF, 2010, p. 22).
}

Esse modelo envolve cinco dimensões (GDF, 2010):

- Dimensão I: habilidades intelectuais - diz respeito à inteligência, habilidade mental geral. Compreende o raciocínio, o planejamento, a resolução de problemas, o pensamento abstrato, a compreensão de idéias complexas, a aprendizagem rápida;

\footnotetext{
${ }^{19}$ Há casos de deficientes visual, auditivo e/ou físico que são deficientes intelectuais também.
} 
- Dimensão II: comportamento adaptativo - reúne as habilidades conceituais sociais e práticas;

- Dimensão III: participação, interações, papéis sociais - verifica-se através do envolvimento da pessoa em atividades sociais cotidianas;

- $\quad$ Dimensão IV: saúde - faz-se referência aqui à saúde física e mental do indivíduo. Definida pela Organização Mundial de Saúde - OMS - como um estado de bem-estar completo, englobando o físico, o mental e o social. Essa dimensão "influencia o funcionamento humano nas demais dimensões" (GDF, 2010, p. 23).

- Dimensão V: contexto social - abrange ambiente e cultura. Tem-se a "descrição das condições interrelacionadas em que vivem as pessoas no seu cotidiano" (idem).

O caderno de Orientação Pedagógica - Educação Especial (idem) acrescenta:

A deficiência intelectual/mental refere-se, portanto, a um estado particular de funcionamento intelectual iniciado na infância, apresenta característica multidimensional e é passível de responder positivamente aos apoios individualizados oferecidos à pessoa. Dessa forma, destaca-se que a avaliação da condição do estudante tem como finalidade a identificação da(s) necessidade(s) do estudante para o conseqüente direcionamento de atendimento(s).

3.2. Sobre a nomenclatura deficiência mental/deficiência intelectual

Por muito tempo foi utilizada a expressão deficiência mental. Sassaki (2005, apud, SILVA, RIBEIRO, MIETO, 2010) explica a diferença desses termos e a utilização nos dias atuais como deficiência intelectual. Justifica-se por se tratar de deficiência no "funcionamento do intelecto". A organização PanAmericana da Saúde e a Organização Mundial da Saúde, em evento no Canadá, aprovaram a Declaração de Montreal Sobre Deficiência Intelectual, onde esse termo passou a vigorar também em outros idiomas (espanhol, francês, inglês). Acredita-se que a criança com deficiência intelectual possui um pensamento desvinculado das experiências concretas e dificuldade em alcançar abstrações mais elevadas. 
Vigotski (idem) redimensiona essa questão ao apontar as relações sociais e o intercâmbio na constituição do sujeito. É "na dinâmica interativa, nas atividades coletivas que os mecanismos de compensação podem ser ativados”. Dessa forma, não se pode determinar a capacidade intelectual do indivíduo por meio de um diagnóstico. Assim sendo:

$$
\begin{aligned}
& \text { "quando conhecemos uma criança que apresenta peculiaridades no seu } \\
& \text { desenvolvimento, nunca podemos dizer qual será o nível mental que ela será } \\
& \text { capaz de atingir. Isso porque o processo de constituição da pessoa é } \\
& \text { ilimitado" (idem). }
\end{aligned}
$$

Essas definições são recentes. Há algumas décadas, eram muito usadas as expressões idiota, imbecil e débil mental, nomeações também utilizadas por médicos e psicólogos e que se propagaram para o meio escolar e social de forma pejorativa (PRIOSTE, RAIÇA, MACHADO, 2006).

Considerando que essa pesquisa trata também das interações sociais, segundo uma perspectiva histórico-cultural, não se pode deixar de falar a respeito da contribuição de Vigotski nos estudos da deficiência intelectual:

\footnotetext{
Para melhor compreender os aspectos pertinentes ao desenvolvimento humano e sua intrínseca relação frente às condições culturais e relações sociais, um dos interesses de Vigotski foi estudar o desenvolvimento de crianças com deficiência num esforço de entender e analisar a constituição de seu funcionamento psíquico superior (ibidem, 2010, p. 208).
}

Segundo estudos de Vigotski (idem), a identificação apenas de aspectos biológicos não explica o funcionamento da mente. Os aspectos sociais, o contexto cultural e a forma de estabelecer as relações sociais também compõem a formação do indivíduo. A criança com deficiência e sem deficiência passa pelas mesmas leis gerais e o que as diferenciam está determinado pelas suas interações. Um dos grandes marcos deste autor foi compreender a deficiência além de um prognóstico clínico, que enfatiza as limitações e "defeitos", caracterizando-as na sua ineficiência. As observações à luz das interações dão a criança possibilidades, ressaltando o que ela pode atingir. Assim para compreender a capacidade intelectual de um indivíduo deve-se guiar pelas suas relações interpessoais. Para Vigotski "a limitação ou o déficit torna-se um potente impulso para o sujeito avançar, justamente porque cria obstáculos, proporcionando 
estímulos à produção de uma compensação em função da plasticidade do funcionamento humano" (ibidem, 2010, p. 211).

Atualmente, existem alguns especialistas na área que estabelecem certas características que são comuns aos indivíduos com deficiência intelectual: falta de concentração, entraves na comunicação e na interação, menor capacidade para entender a lógica de funcionamento das línguas - por não compreender a representação escrita ou necessitar de um sistema de aprendizado diferenciado ${ }^{20}$. Tais aspectos serão observados durante a análise da pesquisa de que trata o presente trabalho.

\subsection{O desafio da escola em estimular o sujeito com deficiência intelectual}

\section{"Uma criança deficiente não é uma criança defeituosa"}

(VIGOTSKI, apud SILVA, RIBEIRO, MIETO, 2010)

Vigotski também defende em seus estudos a importância da mediação. A escola tem uma obrigação maior diante desse novo paradigma educacional. Frente a tanta diversidade é imprescindível buscar alternativas pedagógicas que possibilitem o avanço desses(as) estudantes que possuem alguma particularidade (ou necessidade especial). Considerar as diferentes formas de aprender, as diferenças culturais que permeiam o espaço escolar e as características individuais de cada um faz parte desse novo "fazer pedagógico":

\footnotetext{
O sujeito com deficiência intelectual pode, ao entrar em contato com os signos culturalmente construídos e compartilhados na escola, ativar mecanismos de compensação, (re) organizar qualitativamente suas ações no mundo. A dinâmica pedagógica das operações que o sujeito efetua com a palavra e, consequentemente, com a possibilidade de formar conceitos (ibidem, p. 212).
}

Ao considerar os estudos de Vigotski e a importância que ele dá as interações sociais e os fatores histórico-culturais, alguns dos seguidores de suas ideias apresentam sugestões de como organizar o ambiente escolar para facilitar e estimular estudantes com deficiência intelectual. Como, a princípio, tem como características ${ }^{21}$ dificuldade

\footnotetext{
${ }^{20}$ OLIVEIRA, Anna Augusta Sampaio, Departamento de Educação Especial da Universidade Estadual Paulista Júlio de Mesquita Filho (UNESP, apud Nova Escola, 2009).

${ }^{21}$ Observado nos estudantes analisados nessa pesquisa.
} 
de concentração, o ideal é que as aulas sejam práticas e instrumentalizadas: "Não adianta insistir em falar a mesma coisa várias vezes. Não se trata de reforço. Ele(a) precisa desenvolver a habilidade de prestar atenção com estratégias diferenciadas para, depois, entender o conteúdo" (MANTOAN, apud, Nova Escola, 2009, edição 223).

Como sugestão pode-se começar com a utilização de recursos que o(a) mantenha atento(a) e possibilite a interação com seus colegas. Quebra-cabeça, jogo da memória, cálculo mental, músicas, brincadeiras orais, poemas, parlendas são recursos a serem utilizados independente da idade e que são facilmente adaptados de acordo com a realidade da classe e do(a) estudante (Nova Escola, 2009).

Dada a importância de Vigotski nesse estudo, a utilização dos recursos citados anteriormente, reforça a sua ideia de que as interações sociais, os fatores históricoculturais, bem como uma boa mediação em sala de aula, minimizam a importância que se dá à deficiência. Ela o caracteriza, mas não determina o seu sucesso ou fracasso acadêmico. Vale oferecer condições adequadas para o indivíduo aprender e descobrir seu potencial. 


\section{4 - A APRENDIZAGEM MATEMÁTICA}

A matemática, culturalmente, é a disciplina que mais "reprova" na escola. O ensino da matemática mudou e tiveram-se muitos avanços. Aprender matemática hoje envolve habilidades e competências que permitem ao indivíduo enfrentar as várias situações que o mundo apresenta:

[...] um agregado de habilidades, conhecimentos, crenças e hábitos da mente, bem como as habilidades gerais de comunicação e resolução de problemas, que os indivíduos precisam para efetivamente manejar as situações do mundo real ou para interpretar elementos matemáticos ou quantificáveis envolvidos em tarefas (CUMIMING; GAL; GINSBURG, 1998, p.2, apud CONCEIÇÃO, 2004, p.94).

De acordo com as experiências em sala de aula e segundo a maioria dos estudiosos na área, essa nova concepção de educação matemática, possibilita criar condições para que os(as) estudantes incluídos(as) em classes regulares aprendam. O processo ensino-aprendizagem depende muito mais das intervenções feitas pelo professor, das interações entre pares que acontecem no ambiente escolar, do que das condições físicas ou intelectuais em que se encontram. Moysés (1997, p. 37) afirma que:

Conhecendo a zona de desenvolvimento proximal do aluno, o professor bem preparado saberá fazer as perguntas que irão provocar o desequilíbrio na sua estruturação cognitiva fazendo-a avançar no sentido de uma nova e mais elaborada reestruturação.

Embora acredite que a relação que se estabelece entre os(as) estudantes e deles(as) com o(a) professor(a) propiciem um ambiente de aprendizagem favorável, ainda tenho alguns questionamentos quanto à afirmação acima. De que modo isso pode ser feito? Até que ponto as intervenções podem mudar o curso do desenvolvimento do(a) estudante? Tais indagações serão respondidas mais adiante. No momento atenção será voltada para compreendermos os avanços da educação matemática, numa perspectiva "vigotskiana". 


\subsection{O conhecimento matemático numa perspectiva sócio-histórica}

Ao começar o desenho desse capítulo, considerado o mais instigante, pois ainda na atualidade, é um desafio "vencer" os obstáculos e "pré-conceitos ${ }^{22}$ existentes no ambiente escolar e na sociedade.

Há muitas contradições, principalmente ao se olhar em volta e perceber o quanto o mundo e o ser humano são “matematizados”(Muniz ${ }^{23}$ ). Vive-se cercado (na natureza e nas construções) de formas geométricas, o homem é envolvido com a matemática desde o instante em que acorda. A matemática está presente na relação tempo e espaço, na alimentação, nas relações econômicas (créditos/débitos bancários, gastos, salários, impostos). Os Parâmetros Curriculares Nacionais (1998), pautam o ensino da matemática segundo princípios, bem explicitados por Giancaterino (2009): é um componente importante na construção da cidadania, pois cada vez mais a sociedade necessita se apropriar de recursos tecnológicos e conhecimentos científicos; precisa ser mais democrática e estar ao alcance de todos; a construção e apropriação do conhecimento pelo(a) estudante servirá para compreender e transformar sua realidade. A "matemática como um instrumento de emancipação", permite que ele(a) fale, escreva, saiba interpretar informações gráficas, desenhos, construções, aprenda como organizar e tratar dados. Na verdade, um "ser matematizado" é muito mais do que aquele que sabe fazer contas, decorar e utilizar fórmulas, em situações totalmente desvinculadas da sua realidade. A matemática "talvez seja um dos campos onde melhor se observa o fenômeno do 'encasulamento' ou 'encapsulamento' da escola" (RESNIKI, 1987, p. 15 apud MOYSÉS, 1997, p. 59).

Para ilustrar o que está escrito e descrito até aqui, visando um entendimento melhor do leitor acerca da aprendizagem matemática real e ideal, Moysés (1997) menciona em sua obra a solução de um problema apresentado por Schoenfeld ${ }^{24}$ : "Em um ônibus do exército cabem 36 soldados. Se 1.128 soldados precisam ser transportados para um local de treinamento, quantos ônibus serão necessários?”. Segundo dados observados por Schoenfeld 70\% dos(as) estudantes, aproximadamente,

\footnotetext{
22 Quis enfatizar que muito do "fracasso" que encontramos na aprendizagem matemática se dá porque, historicamente, é uma disciplina que carrega consigo o estigma da dificuldade e do(a) professor(a) muito exigente. São raros(as) os(as) professores(as) que conseguem manter uma relação boa com os(as) estudantes em sala de aula.

23 Professor Muniz sempre faz referência a esse "SER MATEMATIZADO”, em seus discursos.

${ }^{24}$ Já apresentei esse problema (está presente em livros didáticos) em sala de aula, em turma de EJA, e as observações feitas no presente texto se confirmam.
} 
acertaram a operação aritmética. Ao dividir 1.128 por 36, obtiveram como resultado o quociente 31 e resto 12 . Apesar da "conta" correta, apenas 23\% responderam que seriam necessários 32 ônibus. Os demais registraram como resposta 31 e resto 12. "Pensamento matematicamente correto, mas destituído de sentido" (idem). Muitos dos(as) estudantes conseguem ter um bom desempenho matemático fora da escola, nas diversas situações em que se depara no dia-a-dia, porém na escola o que ele(a) vê são situações desprovidas de sentido, sem relação com a sua vida." O saber da escola anda na contramão do saber da vida"(idem).

\subsection{O ensino da Matemática na atualidade}

De tudo que foi comentado até aqui, não se pode achar que a matemática estaria fora desse novo contexto pedagógico. Ela, enquanto Ciência, também recebe suas influências e não poderia ser desvinculada das práticas sociais. Em se tratando de conceito científico, os espontâneos foram indispensáveis no avanço desses estudos, considerando que o homem matematizou a sua vida, desde a sua existência. Como exemplo, pode-se pensar na criação dos números. Eles foram inventados e reinventados à medida que o próprio homem avançava nas suas conquistas e precisava de registros. $\mathrm{O}$ processo de contagem foi sendo necessário para atender situações práticas. Um pastor precisava contar seu rebanho; um agricultor, conhecer o clima e as estações do ano para garantir boa plantação e colheita; suas primeiras construções exigiam conhecimentos de geometria e de medidas e certamente essas construções matemáticas partiram de situações do dia-a-dia até tornarem-se conhecimentos científicos, mediatizados pelo homem, a partir de contextos histórico-sociais.

Embora no ocidente a aproximação da matemática com o pensamento de Vigotski tenha se efetivado recentemente, há muito tempo é campo fértil entre os soviéticos para pesquisas sobre o desenvolvimento das funções mentais superiores. De doze artigos produzidos (1930-1960) por esses pesquisadores, dois abordavam o ensino da matemática (KRUTETSKY e KALMYKVA, apud Moysés, 1997).

Ainda na mesma obra, o campo da educação matemática com enfoque sociocultural surge a partir do Terceiro Congresso Internacional de Educação Matemática, Alemanha, 1996. Um campo em expansão. No Brasil, tem-se D’Ambrosio, como representante da etnomatemática. Ela é uma das grandes responsáveis pela preocupação de muitos estudiosos em reconhecer a influência dos fatores culturais 
como a língua, hábitos, costumes, modo de viver sobre o ensino e a aprendizagem matemática. Para D’Ambrosio, o pensamento de Vigotski e seus discípulos foi preponderante nessa mudança de paradigma, também responsável pelas alterações no currículo. Hoje essa aprendizagem é tratada numa abordagem contextualizada dos conteúdos, exigindo que o(a) professor(a) busque diferentes fontes de informação e formação para aproximar a matemática da realidade sociocultural de seus(suas) educandos(as).

A fim de complementar o assunto discute-se aqui a percepção que Nunes (1997) tem sobre a aprendizagem matemática, onde enfatiza que a "aprendizagem das crianças não é independente da complexa estrutura social na qual elas fazem esta aprendizagem" (idem, p. 101). O progresso esperado pela criança sobre a aprendizagem matemática não é apenas um assunto explicado apenas em seus aspectos cognitivos. Os fatores sociais são relevantes e devem ser lembrados durante todo o processo. A Matemática, nesse sentido, é "uma forma de pensar" (ibidem, p. 105). Dar um sentido real àquilo que se aprende na escola é o grande desafio, pois fora dela o homem é capaz de solucionar muitas situações matemáticas que a vida social lhe impõe. Cabe aos(as) educadores(as) matemáticos(as) se imbuírem dessa responsabilidade e descobrir, quem sabe, através da contextualização o tipo de operação mental utilizado pelo(a) estudante tanto na realização de cálculos quanto na resolução de problemas. Para os que possuem algum tipo de deficiência o desafio é maior, visto que ainda se coloca à frente desses estudos a deficiência. Não é uma discussão a se esgotar nos capítulos seguintes. É preciso entender melhor como se processa esse pensamento, partindo do pressuposto que todos podem aprender e os recursos utilizados com um devem ser utilizados com outros. Apenas a forma como se conduz determinados assuntos pode ser a chave dessa questão.

\section{3. $\mathrm{O}(\mathrm{A})$ educador(a) matemático em uma mediação diferente}

Ao considerarmos as mudanças apontadas no campo da educação matemática, diante da ideia da contextualização, da resolução de problemas ${ }^{25}$, pode-se concluir que um novo perfil de educador(a) matemático(a) precisa estar presente nas instituições de ensino, na tentativa de resgatar um conhecimento que é vivenciado nas ruas e tratado apenas cientificamente na escola. Como foi visto em capítulo anterior, o conceito espontâneo e o conceito científico interagem. Não adianta mudar os objetivos, a

\footnotetext{
25 Será apresentada no capítulo posterior.
} 
concepção de ensino, se quem detém essa responsabilidade permanece o mesmo, utilizando e reproduzindo os mesmos recursos apreendidos quando estudante (CAMPOS; NUNES, 1994). Esses mesmos autores sugerem que o papel desse educador contemporâneo é levar o(a) estudante a:

[...] reconstruir modelos matemáticos que ele compreenda em outras situações, representá-los de maneira a poder utilizar os mais poderosos sistemas simbólicos da Matemática, como instrumento de pensamento, utilizá-los em uma variedade de situações que lhe dêem significado (idem, p. 6-7).

É importante, a partir do exposto, o(a) professor(a) se perceber em três posições distintas e que se completam. A posição sociológica, no qual o(a) educador(a) de hoje tem uma representação social a ser conquistada por uma nova maneira de interagir com seus(suas) aprendizes/professores(as) estudantes. A posição antropológica, tornandoo(a) consciente dos(as) aprendizes/professores(as) estudantes a fim de auxiliá-los(as) na construção do seu próprio futuro. A posição epistemológica e histórica, engajando-o(a) no processo de reavaliação daquilo que é realmente importante para compor o currículo.

Para Marincek (2001), ensinar matemática é muito mais do que promover a aprendizagem de técnicas e memorização de fórmulas. Deve-se assegurar aos(às) estudantes a percepção de que o conhecimento matemático é construído através das oportunidades em estabelecer as relações entre o que sabem e o que estão aprendendo. Segundo Marciano (1998, p. 64):

Para aprender Matemática é preciso construir os sentidos dos conhecimentos e, para isso, é preciso resolver problemas e refletir acerca desse trabalho. Para que as crianças construam o sentindo do conhecimento não basta que reconheçam as situações para as quais eles são úteis. É preciso também conhecer os limites de sua utilização: em que momentos é necessário utilizar outra técnica, como se relacionam os diversos conceitos, quais as melhores formas de representação para tratar e obter a informação, como controlar os resultados.

Assim, complementando suas ideias, a matemática passa a ser uma ferramenta na resolução de problemas e espera-se que as crianças resolvam problemas para 
aprender matemática e não ao contrário, que conheçam matemática para resolver problemas.

Nesse sentido, torna-se fundamental compreender a importância da resolução de problemas no ensino da matemática e de que forma esse novo enfoque pode auxiliar estudantes com deficiência intelectual, considerando para isso um novo papel para o(a) educador(a) matemático(a) num contexto social diferente.

Independente das características do indivíduo é importante compreender que a sociedade precisa de cidadãos mais atuantes, capazes de tomar decisões, fazer escolhas assertivas e conviver com a diversidade de forma a eliminar os preconceitos que ainda existem no meio social:

É necessário formar cidadãos matematicamente alfabetizados, que saibam como resolver, de modo inteligente, seus problemas de comércio, economia, administração, engenharia, medicina, previsão do tempo e outros da vida diária. E, para isso, é preciso que a criança tenha, em seu currículo de Matemática elementar, a resolução de problemas como parte substancial, para que desenvolva desde cedo sua capacidade de enfrentar situaçõesproblema (DANTE, 1995, p.15).

Para isso é preciso fazer o(a) estudante “pensar produtivamente”(ibidem, p. 11). Pensar produtivamente independe de características físicas, mentais, intelectuais. Tornase imprescindível, nessa nova abordagem, também adotar uma postura que favoreça as interações. Elas acontecerão quer favoreça ou não esse processo em sala de aula.

Ao resolver problemas mobilizamos estruturas mentais, por vezes, não tão previsíveis e compreensíveis, mas que favorecem a descoberta de caminhos que possam auxiliar na compreensão desses mecanismos a partir das situações-problema. Dessa forma, em situação de aprendizagem e partindo de situações-problema estudantes necessitam antecipar e formular resultados, justificativas, criar argumentos e reproduzir o processo de descoberta. Ele(as) necessitam por em prática tudo o que sabem, que contém algo novo e ainda não tem resposta e exige investigações e busca de soluções (MARINCEK, 2001).

Quando se fala em mobilizar estruturas mentais, acredita-se que a resolução de problemas passa a ser um elemento indispensável no desenvolvimento dessas estruturas no sentido de fazer a criança ou o(a) adolescente "pensar no que pensou". Para Dante 
(2009) resolver problemas pode auxiliá-los na apreensão de significados e para isto, traça algumas metas, entre elas:

- fazer pensar;

- desenvolver o raciocínio lógico;

- ensinar a enfrentar situações novas;

- conhecer as primeiras aplicações matemáticas;

- aulas mais interessantes e motivadoras.

Acrescentaria:

- torná-lo(a) mais autônomo;

- valorizar os conceitos espontâneos;

- promover maior interação entre os pares, permitindo o diálogo em busca das soluções;

- finalmente, a possibilidade de auxiliar e conhecer um pouco mais as estruturas mentais de estudantes com deficiência intelectual.

Ao organizar o processo de resolução de problemas Pólya ${ }^{26}$ estabeleceu quatro etapas importantes, apresentadas por Dante (1995) e que são mencionadas em seus livros como apoio didático:

- compreender o problema;

- elaborar um plano;

- executar um plano;

- verificação ou retrospectiva;

- emissão de resposta ${ }^{27}$.

Ao examinar cada fase pode-se compreender melhor a sua importância nos estudos dessa pesquisa. Elas complementam as abordagens feitas anteriormente em relação à zona de desenvolvimento proximal, conceitos espontâneos e científicos, linguagem e pensamento, interações, contextualização, aprendizagem e desenvolvimento. São consideradas etapas da resolução: compreensão do problema; elaboração de um plano para a solução; execução do plano; verificação ou retrospecto; emissão de resposta. A seguir, serão detalhadas cada uma destas etapas.

A compreensão do problema corresponde à fase em que, antes de iniciar o processo de resolução, se faz necessário responder algumas questões: $\mathrm{O}$ que se pede no problema? O que se procura no problema? O que se quer resolver no problema? O que o

\footnotetext{
26 George Polya, matemático húngaro que dividiu a resolução de problemas em quatro etapas.
}

27 Foi considerada como etapa, posteriormente. 
problema está perguntando? É possível resolvê-lo utilizando figura, gráfico, tabela ou representá-lo por meio de esquemas? É possível estimar ou chutar a resposta?

$\mathrm{Na}$ etapa de elaboração de um plano de ação para resolver o problema, importa que seja feita a conexão entre as informações que o problema apresenta e o que ele pede. Devem-se considerar as seguintes questões: Você já resolveu um problema parecido? Qual é o seu plano para resolver o problema? Que estratégias você utilizará na solução? É possível resolver o problema por partes? Organizar os dados em gráficos, tabelas ou diagramas pode ajudar na solução. Resolver o problema por partes.

Em seguida, ao executar o que foi planejado deve-se verificar cada passo a ser dado.

Na etapa de execução os cálculos indicados no plano são realizados. É a vez de analisar a solução obtida, fazendo um retrospecto e verificando o resultado. A importância dessa etapa se dá em função da oportunidade do(a) estudante rever como pensou inicialmente (pensar como pensou) até chegar a solução encontrada. Hora de refazer, "tirar a prova" e, se for o caso, corrigir os possíveis enganos identificados. Pode-se aqui identificar uma estratégia a ser empregada em outros problemas.

A importância da etapa final, emissão de resposta, em estudos e observações, se deve ao fato de que ao encontrarmos um resultado numérico, este nem sempre significará a resposta ao problema proposto ${ }^{28}$.

Os procedimentos sugeridos por Polya não determinam, necessariamente, uma obrigatoriedade em seguir essa sistematização, isto poderia tornar a tarefa enfadonha. A sua importância se dá em função de proporcionar a qualquer estudante uma forma de relacionar seus conhecimentos espontâneos e transformá-los em saberes mais elaborados, conforme já foi descrito anteriormente em outros capítulos. Para Dante (1995, p. 30):

\footnotetext{
Ensinar a resolver problemas é uma tarefa mais difícil do que ensinar conceitos, habilidades e algoritmos matemáticos. Não é um mecanismo direto de ensino, mas uma variedade de processos de pensamento que precisam ser cuidadosamente desenvolvidos pelo aluno com o apoio e incentivo do professor.
}

${ }^{28}$ Como demonstra o problema dos 1128 soldados, apresentado no capítulo IV, seção 4.1. 
Seguindo esses passos o(a) professor(a) oportuniza ao(à) estudante refletir sobre seus processo de aprendizagem de forma contínua, estendendo-se ao longo da vida, conforme vá atuando em diferentes situações e circunstâncias (Moysés, 1997).

4.4. O processo de resolução de problemas para o(a) estudante com deficiência intelectual

$\mathrm{Na}$ seção anterior foi abordada a importância da resolução de problemas, considerando que o conhecimento matemático é provido de sentido e realidade. Como pensar nessa perspectiva ao lidar com o(a) estudante com deficiência intelectual?

Viu-se também que para solucionar um problema é necessária a utilização de alguns instrumentos facilitadores da aprendizagem - neste caso, as etapas propostas por Polya. É dada uma situação, o indivíduo precisa resolvê-la e no dado momento não dispõe de um caminho rápido, direto que solucione a situação-problema apresentada (LESTER, 1983, apud ARAÚJO ${ }^{29}, 2005$ ).

Para Araújo (2005) solucionar problemas é uma tarefa difícil para qualquer pessoa sem deficiência quando se trata de problemas complexos e abstratos. Ao observar pessoas com deficiência intelectual, percebe-se, nessa mesma situação, um ponto de fracasso. Pesquisas realizadas a respeito desse assunto mostram que estudantes com deficiência intelectual conseguem realizar tarefas cognitivas simples, porém não são capazes de resolverem sozinhos problemas de ordem complexa. Dentre os motivos apontados por pesquisadores da área, temos a dificuldade acentuada, por parte desses(as) estudantes, na execução que exija uma elaboração mental mais complexa. Estes estudiosos afirmam, ainda, que esse grupo de estudantes utiliza pouco mecanismo de controle, planejamento e conhecimento de suas habilidades. Possui também dificuldades em planejar e aplicar estratégias de solução; raramente produz e generaliza de forma espontânea (CAMPIONE; BROWN, 1978; MINSKY; SPITZ; BESSELLIEU, 1985, apud, idem).

Apesar das dificuldades, observadas e comprovadas por meio de pesquisa, há outras que têm provado que estudantes com deficiência, com as intervenções adequadas, aprendem estratégias de solução de problemas. Erez e Pelet (2001, idem), realizaram uma pesquisa com estudantes com deficiência intelectual e conseguiram provar que

29 Vale a pena ler na íntegra os relatos dessa pesquisa. 
esses(as) possuem algum grau de metacognição e devem ser estimulados(as) desde cedo. Esse seria um elemento-chave para promover a aprendizagem dos(as) mesmos(as). Em outros estudos, tal como o de Tanaka et al., (2001, idem) conclui-se que pessoas com deficiência intelectual utilizam as pistas externas como guias, embora esse recurso tenha sido observado mais em adultos, devido a grande quantidade de experiências fracassadas pelas quais passaram ao longo da vida. Dessa forma torna-se imprescindível, na concepção de outros pesquisadores, que essas experiências comecem cedo. Para Ferretti (1989, apud idem), estudantes com deficiência intelectual, apresentarão estratégias de solução, desde que compreendam o que o problema está apresentando. Infelizmente por mais importante que seja para o currículo e dentro dessa concepção nova de educação matemática, pouco valor se dá a essa área em se tratando de estudantes com deficiência intelectual (AGRAN et al.2002, apud, idem).

Araújo (2005, p. 406) complementa seus estudos ao concluir:

\footnotetext{
"[...] solucionar problemas ajuda as pessoas a tornarem-se mais capazes de usar seu raciocínio, então pensamos que talvez um caminho para as pessoas com deficiência mental, considerando-se seu desenvolvimento cognitivo, seja investir em pesquisa e no ensino de solução de problemas para essas pessoas $[\ldots] "$.
}

Parece que as observações apresentadas em relação à resolução de problemas em estudantes com deficiência intelectual corroboram com os textos e reflexões apresentados até aqui. Em se tratando de deficiência, é importante compreendermos que a capacidade de compreensão está também intimamente ligada às estratégias utilizadas pelo(a) professor(a) em sala de aula no sentido de mobilizar os recursos mentais que cada um(a) possui em busca de solucionar os desafios e problemas que são apresentados na escola. Afinal, como bem menciona Araújo (2005): inteligência é a capacidade de selecionar, comparar e combinar, de pensar sobre o próprio pensamento.

Assim, as estratégias de solução de problemas, apresentadas no capítulo anterior, são elementos importantes nessa reconstrução. É primordial pensar em formas de intervenção que favoreçam melhor a compreensão desses(as) estudantes no espaço escolar e que possam utilizar dessas ferramentas para solucionar as várias situações reais em que irão se deparar frequentemente no contexto sociocultural. 


\section{5 - OBJETIVOS}

\subsection{Objetivo Geral}

Analisar estratégias que favoreçam a aprendizagem matemática de estudantes com necessidades educacionais especiais, atendidos em Sala de Recursos.

\subsection{Objetivos Específicos}

- Identificar a importância da interação entre pares no processo de aprendizagem matemática.

- Identificar a relevância das adequações curriculares nas atividades matemáticas realizadas pelos alunos atendidos em Sala de Recursos, que possam ser utilizadas na sala de aula regular, pelo(a) professor(a)regente. 


\section{6 - METODOLOGIA}

\subsection{A Metodologia qualitativa}

No presente capítulo será tratada, inicialmente, da metodologia escolhida para a realização da pesquisa: a pesquisa qualitativa. Um dos seus aspectos principais, segundo González (2007) é o seu caráter dialógico, numa construção e interpretação da realidade, considerando a subjetividade do sujeito, inserido em seu contexto social:

\footnotetext{
Os novos paradigmas de ciência permitem que nos desloquemos dessas visões ligadas a leis gerais e a modelos normativos, que configuram um mundo ordenado e previsível, para outras visões em que a turbulência, as oscilações e a novidade fazem parte do cotidiano e a inovação faz parte da construção da mudança para um futuro aberto, e que são próprias da educação (BRANCO; VALSINER, 1997; 1999; GONZÁLEZ-REY, 1997; 1999; 2005; KINDERMANN; VALSINER, 1989, apud, MACIEL, RAPOSO, 2010, p. 73).
}

Para Maciel e Raposo (2010), tanto a ciência, quanto a pesquisa são dialógicos e a narrativa que se propõe é composta de autores, em um universo plural, multidimensional. Torna-se fundamental, seguindo suas idéias, produzir conhecimento, pensamento. Assim o sujeito pesquisador, como parte integrante, dialoga com o mundo, se expõe e expõe outros, numa postura sempre ética.

A pesquisa objetivada, proposta da metodologia qualitativa, de acordo com Denzin \& Lincoln (1998, apud MELO 2003), traz a possibilidade de reunir métodos múltiplos, perspectivas e observações em único trabalho. Dessa forma, a história de cada sujeito é parte desse material ao considerar a trajetória de vida acadêmica e o quanto cada um(a) foi estimulado(a) durante esse percurso.

Conforme aponta Minayo (2004), a pesquisa qualitativa está direcionada à investigação da realidade, cujo foco principal são as ciências sociais, em especial à Educação. Como indica o autor, na educação as relações humanas e o contexto social possibilitam uma pesquisa cujo foco está na subjetividade. Nessa linha argumentativa, pode-se afirmar que a escolha por este tipo de abordagem se dá uma vez que as interações sociais e as relações humanas não podem ser analisadas unidirecionalmente, mas obedecem ao contexto na qual está inserida. 
Para encerrar essas considerações, parece adequado dizer que a pesquisa apresentada está inserida nessa abordagem, inclusive por tratar das interações e de contexto sócio-cultural, ao longo de sua fundamentação teórica e durante as observações feitas.

\subsection{Contexto da pesquisa ${ }^{30}$}

A presente pesquisa foi realizada em uma instituição de ensino pública localizada numa Região Administrativa do Distrito Federal que atende cerca de 960 alunos assim distribuídos:

\section{Ensino Fundamental Séries Iniciais}

Matutino: 2 turmas de $4^{\mathrm{a}}$ série ( $5^{\mathrm{o}}$ ano).

Vespertino: 1 turma de $4^{\mathrm{a}}$ série ( $5^{\mathrm{o}}$ ano).

\section{Ensino Fundamental Séries Finais}

Matutino: 4 turmas de $7^{\mathrm{a}}$ série ( $8^{\circ}$ ano), 4 turmas de $8^{\mathrm{a}}$ série $\left(9^{\circ}\right.$ ano).

Vespertino: 5 turmas de $5^{\mathrm{a}}$ série $\left(6^{\circ}\right.$ ano $), 4$ turmas de $6^{\mathrm{a}}$ série $\left(7^{\mathrm{o}}\right.$ ano $), 1$ turma de aceleração.

Grande parte dos(as) estudantes que frequenta a escola é oriundo de uma região carente situada próxima a essa região administrativa, concentrando-se a maioria na $4^{\mathrm{a}}$, $5^{\mathrm{a}}, 6^{\mathrm{a}}$ séries e turma de aceleração, do Ensino Fundamental (I e II). Os(As) estudantes das $7^{\mathrm{a}}$ e $8^{\mathrm{a}}$ séries, em sua maioria, são residentes da área urbana dessa mesma cidade. Uma característica que chama a atenção na escola são os talentos na área desportiva. Nesse grupo há atletas que participam de atividades físicas e competições fora do espaço da escola, porém sem grande destaque na vida acadêmica.

A escola possui 28 professores em regência de classe (incluídos professores de Sala de Recursos) e uma professora especialista em LIBRAS que atua diretamente com uma estudante Deficiente Auditiva. Sua atividade se concentra em ensinar a Língua Portuguesa como segunda língua. Atualmente a referida instituição de ensino não dispõe de Orientador Educacional. A direção é composta por: Diretor, Vice-diretor, Assistente Administrativo, Assistente Pedagógico, 2(dois) Coordenadores Gerais e 1(um) Coordenador de Educação Integral, que trata das atividades desenvolvidas pelo

\footnotetext{
${ }^{30}$ Informações colhidas em 2010.
} 
projeto (Mais Educação ${ }^{31}$ - MEC). Das atividades desenvolvidas nesse projeto destacam-se a música, o hip hop, horta e o reforço escolar em matemática e português. Importante esse destaque em virtude da participação nessas atividades, dos(as) estudantes que frequentam a Sala de Recursos.

A Sala de Recursos - espaço de realização da pesquisa - existe desde 2008, onde atuam duas professoras (área de exatas e de códigos e linguagens). Atende 22 alunos apresentando as seguintes necessidades educacionais especiais: deficiência intelectual, TDAH, Síndrome de Asperger, dislexia, esquizofrenia e deficiência física. O horário de atendimento é organizado para que haja um encontro semanal com cada professora, em atendimento individualizado, preferencialmente. Além de computadores, disponibilizados pelo MEC, a sala dispõe de materiais pedagógicos diversos (jogos, livros) que são utilizados pelos(as) estudantes. A escolha da pesquisa voltada para a deficiência intelectual se justifica em virtude da grande quantidade de estudantes na escola com essa característica. Acredita-se ainda que esses estudos e observações vão auxiliar os(as) outros(as) na medida em que o objetivo principal é encontrar alternativas de inclusão acadêmica que permitam favorecer a aprendizagem desses(as) estudantes.

\subsection{Participantes da pesquisa}

A pesquisa contou com a participação de dois estudantes, Ana Júlia ${ }^{32}$ e Pedro ${ }^{33}$, com 13 e 15 anos de idade, respectivamente. A primeira matriculou-se na escola em 2010 e hoje cursa a $6^{\mathrm{a}}$ série $/ 7^{\mathrm{o}}$ ano do ensino fundamental II. O segundo, está na escola desde 2009 onde cursou a $4^{\mathrm{a}}$ série $/ 5^{\circ}$ ano do ensino fundamental e hoje cursa a $6^{\mathrm{a}}$ série $/ 7^{\circ}$ ano do ensino fundamental II. Ambos apresentam diagnóstico de deficiência intelectual e pertencem à família de baixo nível sócio-econômico. Quanto à pesquisadora, licenciada em Matemática pelo $\mathrm{CEUB}^{34}$, hoje com 47 anos, é professora do quadro efetivo da SEE/DF desde 1991, iniciando seu trabalho em Sala de Recursos no ano de 2008.

\footnotetext{
${ }^{31}$ Criado pela Portaria Interministerial no 17/2007. Aumenta a oferta educativa nas escolas públicas com atividades de acompanhamento pedagógico, meio ambiente, esporte, lazer, cultura, artes, etc.

${ }^{32}$ Nome fictício.

${ }^{33}$ Nome fictício.

34 Em 1987, era conhecido como Centro de Ensino Unificado de Brasília, hoje denomina-se Centro Universitário de Brasília - UNICEUB.
} 


\subsection{Procedimentos de construção de informações}

\section{a. Contatos iniciais}

Para dar início a esse estudo, em primeiro lugar, houve uma conversa informal com a direção da escola, onde foram apresentados além da proposta, os objetivos da pesquisa, e os(as) estudantes participantes. Após o consentimento da direção, foi entregue e assinado o termo de concordância autorizando a realização do estudo. A seguir houve também um contato informal com a professora de matemática, propondolhe a utilização de suas atividades durante a pesquisa. Para formalizar o convite, providenciou-se a assinatura do TCLE (Termo de Consentimento Livre e Esclarecido).

Finalizados esses contatos, foi realizada uma reunião formal com os(as) responsáveis pelos(as) participantes a fim de que eles(as) pudessem conhecer os objetivos da pesquisa e consentir nos estudos. Os participantes convidados também estavam presentes na reunião. Na ocasião foram assinados os Termos de Consentimento Livre e Esclarecido ${ }^{35}$ e informados aos responsáveis que a pesquisa seria realizada no espaço da Sala de Recursos em vários encontros durante a semana.

\section{b. Observação:}

Vale destacar que a seção de observação aconteceu no espaço da Sala de Recursos, fora do horário de atendimento dos participantes, evitando assim a interferência dos(as) outros(as) estudantes ou até mesmo a mudança da rotina de atendimentos já estabelecida para cada um(a). Foram previstas observações no período de uma semana.

A Seção de observação teve uma duração total de 8h58min, respeitando a necessidade individual de cada participante em relação ao tempo, e foi dividida em três etapas. A etapa I (atividade da professora regente) compreende as três primeiras seções, realizadas durante três dias. A etapa II corresponde a $4^{\text {a }}$ seção (adequação da pesquisadora), finalizada em um dia e a etapa III está relacionada à $5^{\mathrm{a}}$ e última seção (interação).

Descrevendo cada etapa, temos:

\footnotetext{
${ }^{35}$ Anexo III.
} 
A $1^{\text {a }}$ seção durou $1 \mathrm{~h} 55$ min em atividade individualizada. A $2^{\mathrm{a}}$ seção, também individual, foi utilizada para a conclusão da seção anterior e durou 1h. A $3^{\mathrm{a}}$ seção, com a presença apenas de Ana Júlia ${ }^{36}$, teve duração de $1 \mathrm{~h} 45 \mathrm{mim}$. As três seções iniciais foram utilizadas para a realização das atividades propostas pela professora regente. Quanto à $4^{a}$ seção, foi reservada para a realização das atividades adaptadas, proposta pela pesquisadora, com duração de $2 \mathrm{~h} 08 \mathrm{~min}$, também individualmente. Os participantes concluíram essa tarefa no mesmo dia, porém Ana Júlia demorou mais tempo para terminar. Finalmente, por meio da interação entre os participantes, foi realizada a $5^{\mathrm{a}}$ seção com duração de 2 h10min, utilizando a mesma atividade da seção anterior. Nessa seção foi permitida a utilização da tabuada e da fita métrica.

6.5. Instrumento de pesquisa, técnicas e materiais utilizados

Como instrumentos de pesquisa foram utilizadas atividades elaboradas pela professora regente da $5^{\mathrm{a}}$ série $/ 6^{\circ}$ ano ${ }^{37}$ e as adequações ${ }^{38}$ realizadas pela pesquisadora de modo a facilitar o processo de ensino-aprendizagem matemática dos(as) estudantes atendidos(as) em Sala de Recursos.

Para as observações realizadas, a partir das atividades propostas aos participantes, foram utilizados registros escritos anotados no diário de campo, à medida que os dois participantes cumpriam a tarefa indicada.

a) Material didático utilizado nas sessões

Os materiais utilizados nesse estudo foram: fita métrica, tabuada, diário de campo (local dos registros), canetas, folhas em branco, lápis, borracha, máquina fotográfica.

6.6. Procedimentos de construção de dados

Nessa etapa temos como objetivo a construção dos elementos da pesquisa, significando a transformação dos dados brutos, conseguidos através das observações e

\footnotetext{
36 Não havia concluído a tarefa na seção anterior.

37 Anexo IV.

38 Anexo V.
} 
registros, em informações relevantes, que vão ao encontro dos objetivos propostos no estudo, cumprindo com a expectativa da pesquisadora.

As atividades propostas foram realizadas individualmente e em grupo com observações a respeito da interação social, reconhecendo sua importância no processo de construção do conhecimento matemático, conferindo a validade da pesquisa por meio de coleta dos dados e síntese dessas observações.

Cada um dos participantes recebeu as seguintes orientações iniciais:

$1^{\circ}$ - A atividade inicial deveria ser realizada individualmente, sem utilização de qualquer recurso ou ajuda.

O objetivo dessa etapa era partir dos conhecimentos prévios dos participantes, a respeito do assunto, embora se tratasse de atividade já realizada em sala de aula com a professora regente.

$2^{\circ}$ - Após a realização da primeira tarefa, a próxima seguiria também individualmente, também sem utilização de recursos ou mediação da pesquisadora.

A diferença da primeira tarefa se daria em função das adequações que foram realizadas a partir das observações feitas, com o objetivo de atender a necessidade acadêmica dos participantes. Além da redução do número de questões, houve também alterações de comando, de valores, bem como retirada de questões que, do ponto de vista da pesquisadora, tornaram a atividade "cansativa" e "repetitiva".

$3^{\circ}$ - Na terceira fase seria permitida, além de utilização de recursos, a interação entre os participantes.

Fariam juntos a mesma atividade da etapa anterior, dialogando um com o outro.

A pesquisadora registrou no diário de campo as observações feitas em cada uma das etapas.

Os dados foram construídos pela pesquisadora utilizando o critério da ordem cronológica. Ana Júlia e Pedro realizaram as atividades sozinhos durante quatro dias e juntos no $5^{\circ}$ dia, sob a observação da pesquisadora com anotações no diário de campo. 
Segue o quadro demonstrativo das atividades realizadas, citadas anteriormente:

\begin{tabular}{|c|c|c|c|c|}
\hline \multirow{2}{*}{$\begin{array}{c}\mathrm{N}^{\mathbf{o}} \\
\text { Encontro }\end{array}$} & \multirow{2}{*}{ Objetivo } & \multicolumn{2}{|c|}{ Tempo } & \multirow{2}{*}{ Produto } \\
\hline & & Início & Término & \\
\hline $1^{\mathrm{o}}$ & $\begin{array}{l}\text { Resolver os problemas/exercícios } \\
\text { sugeridos (em sala de aula foi } \\
\text { proposta de prova) pela professora } \\
\text { regente, sem adequação ou outros } \\
\text { recursos didático-pedagógicos. }\end{array}$ & $8 \mathrm{~h} 35$ & $10 \mathrm{~h} 30$ & $\begin{array}{l}\text { Ana Júlia e Pedro } \\
\text { não concluíram a } \\
\text { tarefa nesse dia. } \\
\text { Considerou-se que } \\
\text { seria exaustivo } \\
\text { concluir tudo em } \\
\text { um único dia. } \\
\end{array}$ \\
\hline $2^{\circ}$ & Continuação da Atividade do dia 06. & $8 \mathrm{~h} 30$ & $9 h 30$ & $\begin{array}{l}\text { Apenas Pedro } \\
\text { concluiu a tarefa. }\end{array}$ \\
\hline $3^{\circ}$ & $\begin{array}{l}\text { Continuação da atividade do dia } 06 \\
\text { somente para Ana Júlia. }\end{array}$ & $8 \mathrm{~h}$ & $9 \mathrm{~h} 45$ & $\begin{array}{l}\text { Ana Júlia concluiu } \\
\text { a tarefa, porém } \\
\text { desistiu de } \\
\text { algumas. Nesse dia } \\
\text { Pedro não } \\
\text { compareceu. }\end{array}$ \\
\hline $4^{\circ}$ & $\begin{array}{c}\text { No } 4^{\circ} \text { encontro, proposta } \\
\text { diferenciada. Adequação dos } \\
\text { problemas/exercícios, partindo das } \\
\text { observações feitas. Ana Júlia e Pedro } \\
\text { realizaram a atividade } \\
\text { individualmente, cumprindo a } \\
\text { proposta da pesquisa. }\end{array}$ & $9 \mathrm{~h} 12$ & $11 \mathrm{~h} 20$ & $\begin{array}{l}\text { Ana Júlia e Pedro } \\
\text { concluíram a } \\
\text { atividade, porém o } \\
\text { tempo gasto por } \\
\text { Ana Júlia foi } \\
\text { maior. Estava } \\
\text { exausta ao final e } \\
\text { teve dificuldades } \\
\text { de concentração } \\
\text { para concluí-las. }\end{array}$ \\
\hline $5^{\circ}$ & $\begin{array}{c}\text { Resolver os mesmos } \\
\text { problemas/exercícios, propostos no } \\
4^{\circ} \text { encontro, em dupla, através da } \\
\text { interação com o outro. }\end{array}$ & $9 \mathrm{~h}$ & $1 \mathrm{~h} 10$ & $\begin{array}{c}\text { Concluíram a } \\
\text { atividade com } \\
\text { menos dificuldade, } \\
\text { interagindo e } \\
\text { dialogando com o } \\
\text { outro. Foi também } \\
\text { momento de } \\
\text { mediação da } \\
\text { pesquisadora. }\end{array}$ \\
\hline
\end{tabular}

Uma observação importante na realização das atividades propostas se refere à ordem estabelecida pelas questões. Algumas vezes foi necessário alterar essa ordem 
para que o(a) participante se sentisse mais à vontade na escolha, a partir das dificuldades encontradas por ele(a). Na construção individual, a sequência não foi seguida da mesma forma para os dois participantes. Esse processo de escolha foi livre.

\subsection{Procedimentos de análise dos dados}

Após as anotações feitas no diário de campo sobre as atividades realizadas pelos participantes foi possível perceber aspectos importantes relativos ao modo como pensam e se organizam na solução dos problemas e exercícios propostos, sem ressaltar a deficiência de cada participante. O que se observa nas escolas é que esses(as) estudantes ficam tão estigmatizados que a atenção se concentra muito mais na deficiência do que em encontrar alternativas que os(as) levem a uma aprendizagem matemática significativa.

Nesse contexto, vale destacar o que diz Collares e Moysés (1994, p. 25-31), sobre a "biologização da sociedade:

[...]só consegue se difundir tão rapidamente, e ser tão facilmente aceita, por trazerem si a mesma ideologia que permeia todo o sistema de preconceitos que opera na vida cotidiana de cada homem. Então, é incorporada a esse sistema com grande facilidade, sem conflitos ideológicos -ao contrário, resistir a ela gera conflitos -, e infiltra-se no "bom-senso", no "senso comum", termos usualmente empregados para nomear/escamotear esse sistema de preconceitos no qual opera o pensamento do homem em sua vida de todo dia.( idem)

Essa preocupação se dá em função da própria dinâmica da escola em valorizar tal documentação como meio de garantir o direito do(a) estudante às adequações que já são previstas em lei.

Segundo as autoras o processo de medicalização se difundiu bastante no ocidente e reforça a importância que se dá a essa biologização. Justifica-se a situação do indivíduo e dá-se pouca importância aos aspectos sociais, políticos, econômicos, históricos que também influenciam a vida das pessoas.

Para fins de análise e pesquisa e considerando que o diagnóstico não é um fim, mas um meio de conhecer melhor a vida do(a) estudante, será apresentado um pouco do histórico "biologizante" de cada um dos nossos participantes, antes de se prosseguir com a análise dos resultados. Buscou-se nesse estudo valorizar menos as questões 
biológicas, por acreditar na concepção de Vigotski que foi apresentada ao longo da pesquisa em sua fundamentação teórica.

Ana Júlia, atualmente com 13 anos, cursa a $6^{\mathrm{a}}$ série $/ 7^{\circ}$ ano do ensino fundamental. De acordo com relatório de Avaliação e Intervenção Educacional do ano de 2009 é diagnosticada (segundo laudo médico) com atraso neuropsicomotor, com história de hipotonia ${ }^{39}$ considerada, dentro dos parâmetros da SEE/DF como DMU ${ }^{40}$. Ao enfatizar o termo "biologização" utilizado por Collares e Moysés, acredita-se na importância de suas críticas ao identificar claramente na convivência com Ana Júlia, que essa "possível limitação" não a impediu em nenhum momento de ser uma estudante bem sucedida na escola. É uma estudante muito responsável e estudiosa e aceita as intervenções que são feitas quando realiza as atividades na Sala de Recursos. A sua leitura é ainda muito fragmentada e, algumas vezes, identifica palavras que não estão contidas no texto. A sua desenvoltura permite se socializar bem com seus(suas) colegas a ponto de ajudá-los(as) nas atividades. Enfrenta muitas dificuldades ao interpretar textos e problemas matemáticos, porém não são dificuldades diferentes daquelas apresentadas pelos(as) estudantes "normalizados". Quando foi convidada para participar da pesquisa aceitou prontamente e com muita alegria. Os pais também concordaram com a proposta da pesquisa, que foi explicada e referendada por meio do Termo de Consentimento Livre e Esclarecido ${ }^{41}$.

Pedro, por sua vez, é um estudante de 15 anos, matriculado na $6^{\mathrm{a}}$ série $/ 7^{\circ}$ ano do Ensino Fundamental. A escola dispõe, em seus arquivos na secretaria, de um relatório psicopedagógico do ano de 2008. Segundo informações, contidas nesse documento, Pedro apresenta atraso no desenvolvimento global e retardo mental leve $\mathrm{e}^{42}$. Da mesma forma que Ana Júlia foi tratada, é importante identificarmos em Pedro suas possibilidades de sucesso acadêmico considerando suas características como estudante. De acordo com colegas e professores(as) tem um comportamento exemplar. Todas as atividades que lhe são encaminhadas, tanto em sala de aula regular, quanto no atendimento em Sala de Recursos, são realizadas. Seu caderno é extremamente organizado, é um estudante caprichoso e possui uma caligrafia muito bonita. Guarda todo o material recebido pelos(as) professores(as) em pasta o que reforça seu senso de

\footnotetext{
39 Redução de força muscular.

40 Deficiência múltipla. Compreende duas ou mais necessidades especiais. No caso da estudante pesquisada identifica-se a deficiência mental e a deficiência física.

42 É dessa forma que a deficiência intelectual é definida nos documentos. No sistema da SEE/DF, o diário de classe apresenta a sigla DM (deficiência mental) para identificar esses(as) estudantes.
} 
organização. É muito participativo e faz questão de atuar em todos os eventos que são programados pela escola, sejam atividades internas ou externas. Ajuda seu pai na fabricação de carroças e participa, na comunidade em que mora, de atividades de teatro oferecidas por uma organização espírita. Ao realizar as tarefas em Sala de Recursos, é perceptível que Pedro apresenta dificuldades ao interpretar textos e resolver problemas matemáticos. Não convive bem com frustrações relacionadas às suas dificuldades em realizar os exercícios e avaliações que são propostos pelos(as) professores(as). Em alguns momentos, quando sente muita dificuldade, demonstra alto grau de ansiedade, chegando a manifestações físicas como suor e silêncio absoluto. $O$ melhor, nesse momento, é deixá-lo relaxar até voltar à sua zona de conforto, por isso, algumas vezes, dar-lhe uma nova chance para fazer a atividade.

Quanto à sua participação na pesquisa foi muito receptivo. Sua mãe aprovou a proposta e também assinou o TCLE.

Do que foi exposto, entende-se que é necessário encontrar uma alternativa de trabalho que atenda as especificidades de cada um, independente de deficiência, buscar experiências matemáticas que façam parte de sua vida em primeiro lugar. Também é importante deixar explícito, para o(a) próprio(a) estudante, o que se pretende em cada atividade. Estas por sua vez, devem contemplar tanto a necessidade do(a) estudante, quanto os objetivos propostos para cada conteúdo, pelo(a) professor(a).

Considerando, portanto, as premissas apontadas, a adequação foi feita ao analisar dificuldades relacionadas à interpretação e resolução de problemas, vocabulário, nomenclatura matemática, compreensão das operações matemáticas, tabuada entre outros, fazendo conexão com o que está mais próximo da realidade do(a) estudante, na medida do possível.

No que diz respeito à interação, entendeu-se aqui, para um resultado mais preciso, que seria melhor manter a mesma atividade da etapa anterior, com o intuito de provar que as interações permitem um diálogo entre os pares envolvidos na tarefa e que favorecem o entendimento, auxiliando nas propostas de soluções de cada situação apresentada. A utilização de material concreto auxiliou em algumas discussões entre os participantes. Houve também o momento de mediação da pesquisadora.

Dessa forma, o que se propõe nessa sessão é transcrever e analisar cada etapa do estudo proposto, descritos em quadros que serão apresentados em cada explicação. 


\begin{tabular}{|c|c|c|c|c|}
\hline $\begin{array}{c}\mathrm{N}^{\mathbf{0}} \text { do } \\
\text { exercício } \\
\text { proposto na } \\
\text { atividade }\end{array}$ & $\begin{array}{c}\text { Ordem em } \\
\text { que foi } \\
\text { realizada }\end{array}$ & $\begin{array}{c}\text { Solução } \\
\text { apresentada } \\
\text { (Ana Julia) }\end{array}$ & $\begin{array}{c}\text { Solução } \\
\text { apresentada } \\
\text { (Pedro) }\end{array}$ & $\begin{array}{l}\text { Observações } \\
\text { da } \\
\text { pesquisadora }\end{array}$ \\
\hline 01 & $\begin{array}{c}1^{a} \text { (Ana Júlia e } \\
\text { Pedro) }\end{array}$ & $\begin{array}{l}\text { Desistiu de } \\
\text { resolver. Não } \\
\text { tentou. }\end{array}$ & $\begin{array}{c}\text { Desistiu de } \\
\text { resolver após } \\
\text { várias tentativas }\end{array}$ & $\begin{array}{l}\text { Os comandos } \\
\text { dessa questão não } \\
\text { estavam claros. } \\
\text { Havia erros de } \\
\text { informação. Foram } \\
\text { retificados, porém } \\
\text { retirada na etapa } \\
\text { seguinte, por se } \\
\text { tratar de uma } \\
\text { questão muito } \\
\text { abstrata que não } \\
\text { foi trabalhada } \\
\text { previamente. }\end{array}$ \\
\hline 02 & $\begin{array}{l}\text { 2a (Ana Júlia e } \\
\text { Pedro) }\end{array}$ & $\begin{array}{l}\text { Desistiu de } \\
\text { resolver após a } \\
\text { leitura. Embora } \\
\text { soubesse que 1h } \\
\text { tem } 60 \text { min., não } \\
\text { tentou. }\end{array}$ & $\begin{array}{l}\text { Adicionou todos } \\
\text { os valores } \\
\text { numéricos } \\
\text { apresentados no } \\
\text { problema. } \\
\text { Não acertou a } \\
\text { questão }\end{array}$ & $\begin{array}{c}\text { Como os } \\
\text { problemas } \\
\text { apresentavam } \\
\text { alternativas de } \\
\text { resultados, não } \\
\text { houve preocupação } \\
\text { com o registro da } \\
\text { resposta. }\end{array}$ \\
\hline 03 & $\begin{array}{c}6^{a} \text { (Ana Júlia) } \\
3^{a}(\text { Pedro })\end{array}$ & $\begin{array}{c}\text { Adicionou os } \\
\text { valores numéricos } \\
\text { apresentados no } \\
\text { problema. Como } \\
\text { não encontrou } \\
\text { esses valores nas } \\
\text { alternativas, } \\
\text { desistiu de tentar } \\
\text { novamente. }\end{array}$ & $\begin{array}{l}\text { Primeiro adicionou } \\
\text { os valores. Como } \\
\text { não encontrou uma } \\
\text { das respostas } \\
\text { apresentadas nas } \\
\text { alternativas, } \\
\text { multiplicou, } \\
\text { utilizando todos os } \\
\text { números. } \\
\text { Não acertou a } \\
\text { questão. }\end{array}$ & $\begin{array}{l}\text { Tanto Ana Júlia } \\
\text { quanto Pedro } \\
\text { estavam } \\
\text { preocupados em } \\
\text { conseguir } \\
\text { encontrar uma das } \\
\text { respostas } \\
\text { apresentadas nas } \\
\text { alternativas. Não } \\
\text { houve êxito nesse } \\
\text { sentido. A primeira } \\
\text { ideia de ambos era } \\
\text { solucionar os } \\
\text { problemas } \\
\text { utilizando sempre } \\
\text { uma das operações } \\
\text { aritméticas. }\end{array}$ \\
\hline
\end{tabular}

${ }^{43}$ Atividades realizadas pelos participantes no anexo VI. 


\begin{tabular}{|c|c|c|c|c|}
\hline 04 & $\begin{array}{c}8^{\mathrm{a}} \text { (Ana Júlia) } \\
4^{\mathrm{a}} \text { (Pedro) }\end{array}$ & $\begin{array}{l}\text { Subtraiu os valores } \\
\text { numéricos } \\
\text { apresentados. } \\
\text { Como não } \\
\text { encontrou a } \\
\text { resposta } \\
\text { apresentada nas } \\
\text { alternativas, deu } \\
\text { por concluída. } \\
\text { Não acertou a } \\
\text { questão. }\end{array}$ & $\begin{array}{c}\text { Pedro fez } 2 \\
\text { tentativas. } \\
\text { Primeiro adicionou } \\
\text { os valores. Depois } \\
\text { dividiu, } \\
\text { encontrando na } \\
\text { sua solução uma } \\
\text { das respostas } \\
\text { apresentadas nas } \\
\text { alternativas, } \\
\text { embora incorreta. } \\
\text { Não acertou a } \\
\text { questão. }\end{array}$ & $\begin{array}{l}\text { Em todas as } \\
\text { questões percebeu- } \\
\text { se uma tendência } \\
\text { nos } 2 \text { participantes } \\
\text { de encontrar uma } \\
\text { das alternativas } \\
\text { apresentadas, } \\
\text { mesmo que isso } \\
\text { representasse em } \\
\text { erro na solução } \\
\text { algorítmica. A } \\
\text { interpretação de } \\
\text { ambos se baseava } \\
\text { em leituras muito } \\
\text { fragmentadas dos } \\
\text { problemas, feita } \\
\text { uma única vez, o } \\
\text { que levou ao } \\
\text { entendimento de } \\
\text { que há necessidade } \\
\text { de ensiná-los } \\
\text { primeiro a } \\
\text { organizar o } \\
\text { pensamento, } \\
\text { provavelmente } \\
\text { utilizando as } \\
\text { etapas de solução } \\
\text { de problemas já } \\
\text { explicitadas em } \\
\text { sessão anterior. }\end{array}$ \\
\hline 05 & $\begin{array}{c}8^{\mathrm{a}} \text { (Ana Júlia) } \\
5^{\mathrm{a}} \text { (Pedro) }\end{array}$ & $\begin{array}{c}\text { Começou } \\
\text { utilizando uma } \\
\text { informação que já } \\
\text { era do seu } \\
\text { conhecimento: um } \\
\text { mês tem } 30 \text { dias } \\
\text { (registrou). Seguiu } \\
\text { esse raciocínio até } \\
\text { chegar a } 1980 \text { dias } \\
\text { correspondendo a } \\
66 \text { meses. Um mês } \\
\text { tem } 30 \text { dias, } 2 \\
\text { meses, } 60 \text { dias.... } \\
\text { até chegar a } \\
\text { resposta correta. }\end{array}$ & $\begin{array}{l}\text { Não tentou fazer. } \\
\text { Já estava exausto e } \\
\text { preferiu marcar a } \\
\text { alternativa que } \\
\text { achava ser a } \\
\text { correta. } \\
\text { Desistiu. }\end{array}$ & $\begin{array}{l}\text { Ana Júlia partiu de } \\
\text { um conhecimento } \\
\text { que já possuía e foi } \\
\text { formando uma } \\
\text { sequência de } \\
\text { números que } \\
\text { representava a } \\
\text { quantidade de } \\
\text { meses solicitada } \\
\text { no problema. } \\
\text { Demorou muito } \\
\text { para encontrar a } \\
\text { solução, porém seu } \\
\text { raciocínio estava } \\
\text { correto desde o } \\
\text { início. Faltou fazer } \\
\text { conexões com } \\
\text { outros } \\
\text { conhecimentos que } \\
\text { facilitasse essa } \\
\text { descoberta. }\end{array}$ \\
\hline
\end{tabular}




\begin{tabular}{|c|c|c|c|c|}
\hline 06 & $\begin{array}{c}3^{\mathrm{a}} \text { (Ana Júlia) } \\
6^{\mathrm{a}}(\text { Pedro })\end{array}$ & $\begin{array}{c}\text { Relatou que } \\
\text { lembrava de um } \\
\text { passeio feito na } \\
\text { época do } \\
\text { aniversário de } \\
\text { Brasília. Estudou o } \\
\text { assunto e fez um } \\
\text { trabalho sobre o } \\
\text { mesmo. } \\
\text { Acertou a } \\
\text { questão. }\end{array}$ & $\begin{array}{l}\text { Pedro também } \\
\text { utilizou o mesmo } \\
\text { recurso de Ana } \\
\text { Júlia. } \\
\text { Acertou a } \\
\text { questão. }\end{array}$ & $\begin{array}{c}\text { A situação } \\
\text { proposta na } \\
\text { questão tratava de } \\
\text { assunto da } \\
\text { realidade escolar e } \\
\text { que tinha ligação } \\
\text { com um trabalho } \\
\text { de pesquisa e de } \\
\text { observação por } \\
\text { meio de um } \\
\text { passeio. Partiu de } \\
\text { um conhecimento } \\
\text { espontâneo para o } \\
\text { estudo de um } \\
\text { científico - } \\
\text { SIMETRIA. }\end{array}$ \\
\hline 07 e 08 & $\begin{array}{c}\text { ] } \\
4^{\mathrm{a}} \text { e } 5^{\mathrm{a}} \text { (Ana Júlia) } \\
7^{\mathrm{a}} \text { e } 8^{\mathrm{a}} \text { (Pedro) }\end{array}$ & $\begin{array}{l}\text { As duas questões } \\
\text { dependiam do } \\
\text { reconhecimento } \\
\text { dos termos da } \\
\text { potenciação. } \\
\text { Acertou as duas. }\end{array}$ & $\begin{array}{c}\text { Pedro acertou a } \mathbf{8}^{\mathbf{a}} \\
\text { e errou a } 7^{\mathbf{a}} \text {. } \\
\text { Como nas duas } \\
\text { questões } \\
\text { identifica-se o que } \\
\text { se sabe sobre os } \\
\text { termos da } \\
\text { potenciação, não } \\
\text { ficou claro se ele } \\
\text { sabia essa } \\
\text { informação. }\end{array}$ & $\begin{array}{l}\text { A pesquisadora } \\
\text { não conseguiu } \\
\text { identificar se } \\
\text { ambos conheciam } \\
\text { o significado dos } \\
\text { termos da } \\
\text { potenciação ou se } \\
\text { foi mera repetição } \\
\text { do que foi } \\
\text { trabalhado em sala } \\
\text { de aula. }\end{array}$ \\
\hline 09 & $\begin{array}{c}9^{\text {a }} \text { (Ana Júlia e } \\
\text { Pedro) }\end{array}$ & $\begin{array}{l}\text { Desistiu. Não } \\
\text { realizou a tarefa. } \\
\text { Disse que não } \\
\text { sabia. }\end{array}$ & $\begin{array}{c}\text { Adicionou os } \\
\text { valores numéricos } \\
\text { apresentados, } \\
\text { tentando encontrar } \\
\text { uma das } \\
\text { alternativas. } \\
\text { Não acertou a } \\
\text { questão. }\end{array}$ & $\begin{array}{l}\text { Novamente a } \\
\text { tentativa de } \\
\text { encontrar uma das } \\
\text { soluções } \\
\text { apresentadas. }\end{array}$ \\
\hline $10^{44}$ & $\begin{array}{c}11^{\mathrm{a}} \text { (Ana Júlia) } \\
10^{\mathrm{a}} \text { (Pedro) }\end{array}$ & $\begin{array}{l}\text { Interpretou } \\
\text { corretamente e } \\
\text { identificou a } \\
\text { operação } \\
\text { matemática que } \\
\text { resolveria o } \\
\text { problema. } \\
\text { Acertou a } \\
\text { questão. }\end{array}$ & $\begin{array}{l}\text { Primeiro utilizou a } \\
\text { adição. Não } \\
\text { encontrando o } \\
\text { valor, optou pela } \\
\text { subtração, porém } \\
\text { não resolveu } \\
\text { corretamente, mas } \\
\text { marcou a } \\
\text { alternativa que } \\
\text { mais se } \\
\text { aproximava do seu } \\
\text { resultado. } \\
\text { Não acertou a } \\
\text { questão. }\end{array}$ & $\begin{array}{c}\text { Houve, em ambos, } \\
\text { dificuldade de } \\
\text { entender que as } \\
\text { questões } 10,11 \mathrm{e} \\
12 \text { tratavam do } \\
\text { mesmo problema. }\end{array}$ \\
\hline
\end{tabular}

44 No texto original da atividade faltava um dado no problema (... há 3250 lugares para o público.). Foi acrescentado, posteriormente, ao identificar que estava dificultando a interpretação da questão 11. 


\begin{tabular}{|c|c|c|c|c|}
\hline 11 & $\begin{array}{c}12^{\mathrm{a}} \text { (Ana Júlia) } \\
11^{\mathrm{a}} \text { (Pedro) }\end{array}$ & $\begin{array}{c}\text { Não considerou a } \\
\text { informação } \\
\text { relativa à } \\
\text { quantidade total de } \\
\text { lugares, embora } \\
\text { tenha identificado } \\
\text { a operação } \\
\text { matemática. } \\
\text { Não acertou a } \\
\text { questão. }\end{array}$ & $\begin{array}{c}\text { Utilizou o valor } \\
\text { que correspondia } \\
\text { ao total de homens } \\
\text { presentes e o } \\
\text { resultado da } \\
\text { questão anterior. } \\
\text { Não resolveu a } \\
\text { subtração } \\
\text { corretamente, } \\
\text { embora tenha } \\
\text { identificado que } \\
\text { ela seria necessária } \\
\text { na solução. } \\
\text { Não acertou a } \\
\text { questão. }\end{array}$ & $\begin{array}{c}\text { A maior } \\
\text { dificuldade } \\
\text { apresentada pelos } \\
\text { dois participantes } \\
\text { está relacionada a } \\
\text { interpretação } \\
\text { correta das } \\
\text { informações do } \\
\text { problema. Embora } \\
\text { Pedro apresente } \\
\text { uma leitura mais } \\
\text { fluente, percebe-se } \\
\text { a sua dificuldade } \\
\text { em interpretar os } \\
\text { dados tanto quanto } \\
\text { Ana Júlia. }\end{array}$ \\
\hline 12 & $\begin{array}{c}13^{\mathrm{a}} \text { (Ana Júlia) } \\
12^{\mathrm{a}} \text { (Pedro) }\end{array}$ & $\begin{array}{c}\text { Utilizou o } \\
\text { resultado da } \\
\text { questão anterior e } \\
\text { realizou uma } \\
\text { adição. Não } \\
\text { identificou a } \\
\text { operação } \\
\text { matemática e fez } \\
\text { uma interpretação } \\
\text { errada do } \\
\text { problema. } \\
\text { Também não } \\
\text { acertou a adição } \\
\text { montada por ela. } \\
\text { Não acertou a } \\
\text { questão. }\end{array}$ & $\begin{array}{c}\text { Utilizou o valor } \\
\text { que correspondia } \\
\text { ao } \mathrm{n}^{\circ} \text { de pessoas } \\
\text { presentes no dia e } \\
\text { não que } \\
\text { representava o } \\
\text { total de lugares. } \\
\text { Também não } \\
\text { resolveu de forma } \\
\text { correta a subtração } \\
\text { por ele montada. } \\
\text { Não acertou a } \\
\text { questão. }\end{array}$ & $\begin{array}{c}\text { Idem a observação } \\
\text { anterior. }\end{array}$ \\
\hline 13 & $\begin{array}{c}10^{\mathrm{a}} \text { (Ana Júlia) } \\
13^{\mathrm{a}} \text { (Pedro) }\end{array}$ & $\begin{array}{c}\text { Já havia } \\
\text { demonstrado nas } \\
\text { questões } 7 \text { e } 8 \\
\text { conhecimento } \\
\text { sobre o assunto. } \\
\text { Acertou a } \\
\text { questão. }\end{array}$ & $\begin{array}{c}\text { Resolveu, } \\
\text { embora tenha } \\
\text { errado uma das } \\
\text { questões que } \\
\text { tratava do mesmo } \\
\text { assunto. } \\
\text { Acertou a } \\
\text { questão. }\end{array}$ & $\begin{array}{l}\text { Ambos acertaram } \\
\text { a questão proposta. }\end{array}$ \\
\hline 14 & $\begin{array}{c}14^{\mathrm{a}} \text { (Ana Júlia e } \\
\text { Pedro })\end{array}$ & $\begin{array}{l}\text { Montou a solução, } \\
\text { porém não } \\
\text { resolveu } \\
\text { corretamente a } \\
\text { multiplicação. } \\
\text { Como falou em } \\
\text { voz alta seu } \\
\text { raciocínio foi o } \\
\text { seguinte: } 2 \text { x } 2=4 ; \\
4+2=6 ; 6+2=8 ; \\
8+2=10 . \\
\text { Não acertou a } \\
\text { questão. }\end{array}$ & $\begin{array}{c}\text { Resolveu } \\
2 \times 2 \times 2=8 \text {. } \\
2 \times 2=4 \text {. A seguir } \\
\text { multiplicou os } \\
\text { valores } \\
\text { encontrados, } \\
\text { porém apresentou } \\
\text { resultado } \\
\text { incorreto: } \\
8 \times 4=42 . \\
\text { Não acertou a } \\
\text { questão. }\end{array}$ & $\begin{array}{c}\text { Ana Júlia } \\
\text { demonstra mais } \\
\text { independência nas } \\
\text { suas soluções e } \\
\text { Pedro parece estar } \\
\text { em busca de } \\
\text { modelos que já } \\
\text { foram } \\
\text { apresentados em } \\
\text { sala de aula. } \\
\text { Demonstrou uma } \\
\text { certa ansiedade. }\end{array}$ \\
\hline
\end{tabular}




\begin{tabular}{|c|c|c|c|c|}
\hline 15 & $\begin{array}{l}15^{\mathrm{a}} \text { (Ana Júlia e } \\
\text { Pedro) }\end{array}$ & $\begin{array}{c}\text { Expressou } \\
\text { verbalmente que } \\
\text { não havia } \\
\text { entendido as } \\
\text { informações. } \\
\text { Desistiu. }\end{array}$ & $\begin{array}{c}\text { Representou a } \\
\text { resposta através } \\
\text { das alternativas } \\
\text { apresentadas e não } \\
\text { demonstrou o } \\
\text { raciocínio } \\
\text { construído na sua } \\
\text { resposta. } \\
\text { Não acertou a } \\
\text { questão. }\end{array}$ & $\begin{array}{c}\text { Ambos não } \\
\text { compreenderam as } \\
\text { informações } \\
\text { apresentadas na } \\
\text { questão. }\end{array}$ \\
\hline 16 & $16^{\mathrm{a}}$ (Ana Júlia) & $\begin{array}{c}\text { Ao registrar a } \\
\text { resposta metros } \\
\text { foi questionada } \\
\text { porque não fez } \\
\text { outra escolha. Sua } \\
\text { resposta foi: "Não } \\
\text { é litro porque não } \\
\text { é água. Não } \\
\text { marquei o } \\
\text { quilograma porque } \\
\text { não sei o que é. } \\
\text { Não marquei o } \\
\text { quilômetro porque } \\
\text { não é estrada". } \\
\text { Acertou a } \\
\text { questão. }\end{array}$ & $\begin{array}{l}\text { Pedro não soube } \\
\text { explicar a sua } \\
\text { escolha. } \\
\text { Não acertou a } \\
\text { questão. }\end{array}$ & $\begin{array}{c}\text { Novamente } \\
\text { confirma-se a } \\
\text { espontaneidade de } \\
\text { Ana Júlia. Pedro é } \\
\text { mais introspectivo } \\
\text { e se retrai quando } \\
\text { não se sente seguro } \\
\text { na sua solução. } \\
\text { Ana Júlia } \\
\text { demonstrou com } \\
\text { seus comentários } \\
\text { seus } \\
\text { conhecimentos } \\
\text { espontâneos. Ela } \\
\text { reconhece } \\
\text { superficialmente o } \\
\text { que significa cada } \\
\text { unidade de medida } \\
\text { apresentada, } \\
\text { porém não } \\
\text { ultrapassou essa } \\
\text { etapa. }\end{array}$ \\
\hline $17,18,19$ e 20 & $\begin{array}{l}17^{\mathrm{a}} \cdot 18^{\mathrm{a}}, 19^{\mathrm{a}}, 20^{\mathrm{a}} \\
\text { (Ana Júlia e } \\
\text { Pedro) }\end{array}$ & $\begin{array}{l}\text { Não conseguiu } \\
\text { resolver. Desistiu. }\end{array}$ & $\begin{array}{l}\text { Tentou resolver a } \\
\text { questão } 17 \text {, porém } \\
\text { não foi bem } \\
\text { sucedido. } \\
\text { Tentou resolver } \\
\text { a questão 17 e } \\
\text { desistiu depois. }\end{array}$ & $\begin{array}{l}\text { Ambos já estavam } \\
\text { muito cansados. } \\
\text { As três questões } \\
\text { eram muito } \\
\text { abstratas e nenhum } \\
\text { dos dois sabia } \\
\text { explicar qual era a } \\
\text { "regra" para } \\
\text { resolver expressão } \\
\text { aritmética. }\end{array}$ \\
\hline
\end{tabular}

\section{Etapa II}

Após verificar que havia uma grande quantidade de questões que se repetiam em assunto, houve necessidade de reformular a atividade, respeitando os conteúdos 
$\operatorname{apresentados}^{45}$. Procurou-se nessa escolha, dimensionar a quantidade de questões para evitar a mesma exaustão verificada na etapa anterior. Havia também várias questões sobre o mesmo conteúdo. A opção foi estabelecer prioridades a partir dos objetivos elencados, para melhor compreensão do quadro que será apresentado após essas considerações.

Relembrando as questões apresentadas

A questão $\mathrm{n}^{\mathrm{o}} 1$ tratava de assunto muito abstrato, preferiu-se optar pela sua eliminação, prevendo outro momento para realizá-la, que pode ser apresentada como desafio a ser realizado em parceria. É uma questão que demanda certo tempo para encontrar a solução. As questões $n^{\circ}$ s 2 e 3 tratam de medida de tempo. Optou-se, por tratar de conversão de unidades de medida de tempo, e ao identificar que ambos precisavam passar ainda por essa etapa, reformulá-la. Traçando como objetivo, na questão 5, saber fazer a conversão de mês em dia, ano em meses, preferiu-se trabalhar com valores pequenos, evitando assim, destacar contas exaustivas. A questão 6 foi mantida por se tratar de uma atividade proposta a partir de uma pesquisa vivenciada em passeio pela cidade de Brasília. Como as questões $\mathrm{n}^{\circ} \mathrm{s}$ 7, 8, 9, 13, 14 tratam do mesmo assunto (compreender o significado da potenciação, identificar seus termos e resolvêla), optou-se por duas questões apenas: uma de ordem simbólica e outra representando um problema contextualizado. As questões $n^{\circ}$ s 9, 10 e 11 foram transformadas em uma única questão, tendo como objetivo que os participantes identificassem a operação aritmética necessária para solucionar o problema apresentado. Como a questão $\mathrm{n}^{\circ} 15$ trata de unidade de medida de comprimento, tendo como objetivo transformação de unidade de medida (metro em centímetro); foi permitida a utilização da fita métrica para que os participantes identificassem $100 \mathrm{~cm} \mathrm{em} 1 \mathrm{~m}^{46}$. A partir daí, solucionar o problema apresentado na questão $8^{47}$. O objetivo da questão 16 é reconhecer a unidade de medida de comprimento adequada à situação apresentada. Assim, a mesma questão foi apresentada na atividade reformulada, porém sem alternativas ${ }^{48}$. Em relação as questões $\mathrm{n}^{\circ} \mathrm{s} 17,18,19$ e 20, que tratam de expressões aritméticas, preferiu-se reduzir em uma

\footnotetext{
45 Não cabe aqui fazer qualquer juízo de valor da professora e de sua atividade. Todas as observações que forem elencadas nesse estudo têm como foco o(a) estudante.

46 Questão 7 da atividade reformulada.

47 Essa questão corresponde à atividade reformulada.

48 Optou-se por eliminar na etapa II, as alternativas, evitando que os participantes se influenciassem pelas respostas apresentadas, como aconteceu na etapa I.
} 
única questão mais simples, entendendo (pelo que foi observado na etapa I) que o objetivo é saber resolver expressões aritméticas contendo as operações e os sinais de associação.

Para dar melhor visibilidade ao que foi descrito até aqui, é importante salientar que na etapa I, os participantes resolveram uma atividade composta de 20 questões que foi apresentada à turma na "semana de provas" 49 . Na etapa II, foi reduzida pela metade sem comprometer objetivos e conteúdos. Desta forma, a tarefa tornou-se menos exaustiva e mais objetiva.

Quadro descrevendo a etapa II ${ }^{50}$

\begin{tabular}{|c|c|c|c|}
\hline $\begin{array}{c}\mathrm{N}^{\circ} \text { do } \\
\text { exercício } \\
\text { proposto } \\
\text { na } \\
\text { atividade }\end{array}$ & $\begin{array}{c}\text { Solução apresentada } \\
\text { (Ana Julia) }\end{array}$ & $\begin{array}{c}\text { Solução } \\
\text { apresentada (Pedro) }\end{array}$ & $\begin{array}{c}\text { Observações da } \\
\text { pesquisadora }\end{array}$ \\
\hline 1 & $\begin{array}{l}\text { Dividiu } 180 \text { por 10. Não } \\
\text { conseguiu resolver a divisão. } \\
\text { Não acertou a questão }\end{array}$ & $\begin{array}{c}\text { Apresentou a mesma } \\
\text { solução que Ana Júlia. } \\
\text { Não acertou a questão. }\end{array}$ & $\begin{array}{l}\text { Da forma como foi apresentado } \\
\text { o problema, havia necessidade } \\
\text { de elaborar uma resposta. } \\
\text { Nenhum dos participantes } \\
\text { conseguiu estabelecer a relação } \\
\text { existente entre a hora e o } \\
\text { minuto: } 1 \mathrm{~h} \text { tem } 60 \text { minutos. }\end{array}$ \\
\hline 2 & $\begin{array}{c}\text { Utilizou se conhecimento a } \\
\text { respeito da relação existente } \\
\text { entre mês e dia: } 1 \text { mês tem } 30 \\
\text { dias. Construiu a seguinte } \\
\text { sequência: } 1 \text { mês tem } 30 \text { dias; } \\
2 \text { meses tem } 60 \text { dias e a } \\
\text { assim por diante até chegar } \\
\text { em } 7 \text { meses com } 210 \text { dias. } \\
\text { A resposta registrada foi } 7 \\
\text { meses e não observou que } 7 \\
\text { meses completos passam dos } \\
200 \text { dias apresentados no } \\
\text { problema. Acertou a questão } \\
\text { em parte. }\end{array}$ & $\begin{array}{l}\text { Associou que } 1 \text { mês tem } \\
200 \text { dias e } 4 \text { meses tem } \\
800 \text { dias. Não formulou } \\
\text { uma resposta. Não acertou } \\
\text { a questão. }\end{array}$ & $\begin{array}{l}\text { Ana Júlia seguiu um raciocínio } \\
\text { partindo de um conhecimento } \\
\text { que já possuía, porém não } \\
\text { registrou a resposta } \\
\text { corretamente. Associou sua } \\
\text { resposta ao último resultado } \\
\text { numérico encontrado na } \\
\text { sequência. Pedro não sabia da } \\
\text { relação existente entre mês e } \\
\text { dia. }\end{array}$ \\
\hline
\end{tabular}

${ }^{49} \mathrm{Na}$ "semana de provas" da escola alguns(mas) estudantes com necessidades especiais fazem a prova na Sala de Recursos e, normalmente, levam mais de uma semana para concluir a tarefa se não são feitas as adequações solicitadas pela equipe.

${ }^{50}$ Atividades realizadas pelos participantes no anexo VII. 


\begin{tabular}{|c|c|c|c|}
\hline 3 & $\begin{array}{l}\text { Não formalizou a resposta, } \\
\text { porém fez a representação } \\
\text { correta do eixo de simetria no } \\
\text { desenho. Acertou a questão. }\end{array}$ & $\begin{array}{c}\text { Fez a representação correta } \\
\text { no desenho a registrou a } \\
\text { resposta. Acertou a } \\
\text { questão. }\end{array}$ & $\begin{array}{c}\text { Essa questão partiu de uma } \\
\text { situação vivenciada em um } \\
\text { passeio. }\end{array}$ \\
\hline 4 & $\begin{array}{l}\text { Representou corretamente a } \\
\text { operação e os cálculos. } \\
\text { Acertou a questão. }\end{array}$ & $\begin{array}{c}\text { Fez um registro diferente } \\
\text { de Ana Júlia. Acertou a } \\
\text { questão. }\end{array}$ & $\begin{array}{c}\text { Essa questão alcançou o } \\
\text { objetivo proposto em se } \\
\text { tratando da definição de } \\
\text { potenciação. }\end{array}$ \\
\hline 5 & $\begin{array}{l}\text { Não conseguiu interpretar a } \\
\text { situação apresentada. } \\
\text { Desistiu. }\end{array}$ & $\begin{array}{l}\text { Interpretou corretamente a } \\
\text { situação apresentada, porém } \\
\text { não utilizou todas as } \\
\text { informações. Compreendeu } \\
\text { que se tratava de uma } \\
\text { multiplicação. Acertou a } \\
\text { questão em parte. }\end{array}$ & $\begin{array}{l}\text { As questões que envolvem } \\
\text { apenas contas são resolvidas de } \\
\text { forma mais mecânica (questão } \\
\text { 4). Porém a questão } 5 \text { exigia dos } \\
\text { participantes uma leitura mais } \\
\text { aprofundada, interpretação da } \\
\text { situação, elaboração de uma } \\
\text { plano de ação, bem como o } \\
\text { registro da resposta. }\end{array}$ \\
\hline 6 & $\begin{array}{c}\text { Identificou corretamente a } \\
\text { operação a ser feita, porém não } \\
\text { soube interpretar as } \\
\text { informações do problema } \\
\text { proposto. Subtraiu a quantidade } \\
\text { de homens presentes no torneio } \\
\text { de futebol do total de lugares do } \\
\text { Ginásio, quando na verdade } \\
\text { teria que retirar esse valor da } \\
\text { quantidade de pessoas presentes } \\
\text { no jogo, pois Ginásio não } \\
\text { estava completo. Não acertou. }\end{array}$ & $\begin{array}{l}\text { Adicionou todos os valores } \\
\text { apresentados. } \\
\text { Não interpretou } \\
\text { corretamente as } \\
\text { informações do problema. } \\
\text { Não acertou a questão. }\end{array}$ & $\begin{array}{l}\text { Há uma tendência em utilizar } \\
\text { todos os números apresentados } \\
\text { nos problemas. A solução } \\
\text { apresentada por Pedro já foi } \\
\text { identificada em outros } \\
\text { estudantes que não } \\
\text { apresentavam necessidades } \\
\text { especiais. }\end{array}$ \\
\hline 7 & $\begin{array}{c}\text { Não conseguiu resolver. } \\
\text { Desistiu. }\end{array}$ & $\begin{array}{c}\text { Não conseguiu resolver. } \\
\text { Desistiu. }\end{array}$ & $\begin{array}{l}\text { Nenhum dos participantes sabia } \\
\text { que em } 1 \text { metro há } 100 \mathrm{~cm} .\end{array}$ \\
\hline 8 & $\begin{array}{c}\text { Não conseguiu resolver. } \\
\text { Desistiu. }\end{array}$ & $\begin{array}{c}\text { Não conseguiu resolver. } \\
\text { Desistiu }\end{array}$ & $\begin{array}{c}\text { Para resolver a questão } 8 \text { havia } \\
\text { necessidade de saber da } \\
\text { informação que seria apresentada } \\
\text { na solução da questão } 7\end{array}$ \\
\hline 9 & $\begin{array}{l}\text { Não conseguiu resolver, } \\
\text { embora tenha resolvido essa } \\
\text { mesma questão na etapa } \\
\text { anterior com criatividade. } \\
\text { Desistiu. }\end{array}$ & $\begin{array}{l}\text { Não soube justificar a sua } \\
\text { escolha, embora tenha } \\
\text { acertado a questão. }\end{array}$ & $\begin{array}{l}\text { Essa questão envolve saber } \\
\text { estimar a unidade de medida } \\
\text { adequada à situação. }\end{array}$ \\
\hline 10 & $\begin{array}{c}\text { Não conseguiu resolver. } \\
\text { Desistiu. }\end{array}$ & $\begin{array}{l}\text { Resolveu, mas não } \\
\text { acertou a questão. }\end{array}$ & $\begin{array}{c}\text { Questões muito abstratas e } \\
\text { nenhum dos dois sabia explicar } \\
\text { qual era a "regra" para resolver } \\
\text { a expressão aritmética } \\
\text { apresentada, embora Pedro } \\
\text { tenha se aproximado mais da } \\
\text { solução correta. }\end{array}$ \\
\hline
\end{tabular}


Quadro descrevendo a Etapa III - interação ${ }^{51}$

Para maior entendimento do que vai ser apresentado é importante ponderar algumas coisas a respeito das características individuais de cada participante.

Ana Júlia por ser mais dinâmica e extrovertida opinou mais que Pedro na solução dos problemas propostos, não significando que ela sabia mais. Porém, as suas intervenções iniciais proporcionaram melhor diálogo e a conversa fluiu de forma mais natural à medida em que ambos se sentiam mais à vontade um com o outro.

\begin{tabular}{|c|c|c|}
\hline $\begin{array}{c}\mathrm{N}^{\circ} \text { do } \\
\text { exercício } \\
\text { proposto na } \\
\text { atividade }\end{array}$ & $\begin{array}{c}\text { Solução } \\
\text { apresentada por Ana Júlia e } \\
\text { Pedro }\end{array}$ & Observações da pesquisadora \\
\hline 1 & $\begin{array}{c}\text { Tanto Ana Júlia quanto Pedro erraram essa } \\
\text { questão na etapa anterior. } \\
\text { Juntos, formaram uma sequência, } \\
\text { verbalizada e registrada, da seguinte forma: } \\
\text { 1h tem } 60 \text { min; } 2 \text { horas tem } 120 \text { min; } 3 \text { horas } \\
\text { tem } 180 \text { min. } \\
\text { A seguir subtraíram: } 10-3=7 \text {. Resposta } \\
\text { apresentada: } 7 \text { horas. }\end{array}$ & $\begin{array}{l}\text { Pedro foi rápido ao fazer os cálculos e Ana } \\
\text { Júlia para propor as ideias iniciais. } \\
\text { Fala de Ana Júlia: "Hoje estou mais calma } \\
\text { que ontem. Ontem tava muito nervosa". } \\
\text { Ambos erraram a questão na etapa } \\
\text { individual e resolveram corretamente } \\
\text { juntos. }\end{array}$ \\
\hline 2 & $\begin{array}{l}\text { Montaram a seguinte sequência, partindo de } \\
\text { conhecimentos já adquiridos: } \\
1 \text { mês tem } 30 \text { dias... até chegar em: } 7 \text { meses } \\
\text { tem } 210 \text { dias. }\end{array}$ & $\begin{array}{c}\text { Novamente Ana Júlia tomou a iniciativa. } \\
\text { Aproveitou a solução da etapa anterior. A } \\
\text { diferença está na resposta. Aqui perceberam } \\
\text { que } 7 \text { meses completos não correspondia a } \\
200 \text { dias. Daí, juntos, chegaram a conclusão } \\
\text { que a resposta era } 6 \text { meses e } 10 \text { dias. Vale } \\
\text { lembrar que os dois problemas apresentados } \\
\text { não exigiam a utilização de uma das } 4 \\
\text { operações aritméticas. } \\
\text { Ambos erraram a questão na etapa } \\
\text { individual e resolveram corretamente } \\
\text { juntos. }\end{array}$ \\
\hline 3 & $\begin{array}{c}\text { Acertaram a questão, justificando: "a gente } \\
\text { sabe que é vertical por que fizemos um } \\
\text { trabalho sobre ele". }\end{array}$ & $\begin{array}{l}\text { Ambos já haviam acertado essa questão e } \\
\text { pelo próprio comentário, era uma questão bem } \\
\text { familiar. Fazia parte da realidade vivenciada } \\
\text { na escola através do passeio, tornando o } \\
\text { conteúdo apresentado provido de sentido. }\end{array}$ \\
\hline 4 & $\begin{array}{l}\text { Ambos já haviam acertado essa questão. } \\
\text { Tornou a atividade menos complexa. }\end{array}$ & $\begin{array}{l}\text { Pedro tomou a iniciativa nessa questão. A } \\
\text { solução apresentada partiu dele. }\end{array}$ \\
\hline
\end{tabular}

${ }^{51}$ Atividades realizadas pelos participantes em interação no anexo VIII. 


\begin{tabular}{|c|c|c|}
\hline 5 & $\begin{array}{l}\text { Pedro sugeriu: "Multiplicar o } 3 \text { três vezes": } \\
\qquad 3 \times 3=9 ; 9 \times 3=27 .\end{array}$ & $\begin{array}{l}\text { Na etapa anterior, Ana Júlia não conseguiu } \\
\text { resolver a questão e Pedro explicou como fez. } \\
\text { Embora não tenham encontrado a solução } \\
\text { correta, foi importante essa troca, pois um dos } \\
\text { participantes não compreendeu a ideia } \\
\text { apresentada no problema. } \\
\text { Acertaram essa questão em parte. }\end{array}$ \\
\hline 6 & $\begin{array}{l}\text { A ideia de Pedro inicialmente era subtrair: } \\
\text { 3250-1863. Ana Júlia, por sua vez, sugeriu } \\
\text { que a subtração correta seria: } 2628-1863 \text {. } \\
\text { Resolveram a conta juntos, registrando em } \\
\text { seguida a resposta. }\end{array}$ & $\begin{array}{l}\text { Ambos erraram a questão na etapa } \\
\text { individual e resolveram corretamente } \\
\text { juntos. }\end{array}$ \\
\hline 7 & $\begin{array}{l}\text { Foi fornecida para resolver essa questão a } \\
\text { fita métrica. } \\
\text { Ana Júlia mencionou que "gostaria que as } \\
\text { aulas de matemática utilizassem material". } \\
\text { Chegaram à conclusão, a partir de } \\
\text { observação da fita métrica, que } 1 \text { metro tem } \\
\qquad 100 \text { centímetros. }\end{array}$ & $\begin{array}{l}\text { Ambos erraram a questão na etapa } \\
\text { individual e resolveram corretamente } \\
\text { juntos. }\end{array}$ \\
\hline 8 & $\begin{array}{l}\text { Nem Ana Júlia, nem Pedro resolveram essa } \\
\text { questão na etapa anterior. }\end{array}$ & $\begin{array}{l}\text { Nenhum dos participantes conseguiu } \\
\text { compreender o problema proposto na questão. } \\
\text { Desistiram. }\end{array}$ \\
\hline 9 & $\begin{array}{l}\text { Ambos chegaram à conclusão correta que a } \\
\text { resposta mais adequada é o metro. }\end{array}$ & $\begin{array}{c}\text { Na etapa anterior apenas Pedro havia acertado } \\
\text { essa questão. Resolveram corretamente } \\
\text { juntos. }\end{array}$ \\
\hline 10 & $\begin{array}{c}\text { Como Pedro havia resolvido essa questão na } \\
\text { etapa individual, manteve seu raciocínio e } \\
\text { Ana Júlia concordou com a sua resposta, } \\
\text { porém não estava correta. }\end{array}$ & $\begin{array}{l}\text { Ana Júlia não conseguiu argumentar com } \\
\text { Pedro na solução dessa questão. O jeito de } \\
\text { Pedro predominou, sem interferência de Ana } \\
\text { Júlia. Acertaram a questão em parte. }\end{array}$ \\
\hline
\end{tabular}

\subsection{Resultados e discussão teórica}

Pretende-se nesta seção traduzir, de forma simples, clara e objetiva a experiência vivenciada nesse estudo que tinha como objetivo principal analisar as estratégias que favorecem a aprendizagem matemática de estudantes com necessidades educacionais especiais. Partindo desse pressuposto, salienta-se também a importância das etapas estabelecidas, visando comprovar a importância da interação no processo ensino- 
aprendizagem, mencionado no referencial teórico, a partir dos estudos de Vigotski e seus colaboradores. Vale ainda destacar a relevância das adequações curriculares nas atividades apresentadas, visto que, como veremos, contribuíram para a realização das atividades propostas, a partir das dificuldades observadas, sem comprometer objetivos e conteúdos propostos na atividade.

Para construir as reflexões que foram surgindo à medida que o trabalho foi tomando corpo, foi necessário transformar as informações colhidas durante a pesquisa em tabelas que tornaram mais claros os resultados que serão apresentados. A escolha da pesquisa qualitativa tornou o processo de estudo mais rico, por permitir um diálogo constante nessa relação pesquisador-investigado:

\footnotetext{
Nesse sentido, considera-se que o sujeito, mais que responder um instrumento, expressa através dele, ou seja, elabora e constrói sua experiência, e a expressa de forma diferenciada através do indutor que foi utilizado para estimular sua expressão (MACIEL; RAPOSO, 2010, p. 83).
}

É nesse cenário que foram construídos os resultados a partir das observações e transformações, propiciando uma releitura do que foi apresentado ao longo dos referenciais teóricos escolhidos para esse estudo e que contribuíram de forma significativa nas reflexões finais. Não poderia deixar de ser destacado nesse momento, antes de prosseguir, o que Maciel e Raposo (p. 88) mencionam a respeito do professor como construtor de conhecimento:

\footnotetext{
[...] a teoria pode ser comparada a uma lente que amplia o olhar do professor, ajudando-o a enxergar o que antes não conseguia. Isto é, auxilia o professor olhar para uma mesma situação por diversos ângulos diferentes. A teoria assume um lugar privilegiado, ou seja, a de um instrumento que ajuda o professor apreender sua realidade de uma nova maneira e possivelmente mais enriquecida.
}

Mesmo que o foco da pesquisa seja o(a) estudante com deficiência intelectual, muito das análises feitas estarão voltadas também para a ação do(a) professor(a) e também daqueles(as) estudantes que são considerados(as) "normalizados(as) tanto pela sociedade, quanto pela escola. É preciso entender que as dificuldades apresentadas pelos participantes envolvem situações que são corriqueiras no universo da escola e que independem de características físicas, mentais ou emocionais. A ação e conduta do(a) 
professor(a) diante desse universo também reflete nesse espaço, podendo dificultar ou facilitar seu desenvolvimento ainda que, suas ações decorram da falta de investimento em sua formação.

Propõe-se assim, que a apresentação dos resultados seja feita a partir de cada etapa que já foi explicitada na seção anterior. A etapa I trata da atividade elaborada pela professora regente e que foi proposta de prova na semana de provas da escola, portanto uma atividade já conhecida dos participantes. A etapa II consistiu na reelaboração da atividade proposta, na tentativa de reduzir o número extensivo de questões que gerou certo desconforto aos participantes; e também na análise do que de significativo pode ser extraído dessas questões, de forma que propicie um momento de aprendizado. Aqui, adequação curricular cumpre esse propósito. $\mathrm{O}$ ensino da matemática atual desempenha esse propósito quando destaca a resolução de problemas como "meio para a construção dos conhecimentos matemáticos" (MARINECK, 2001, p. 14). Para ela, na mesma obra, resolver problemas é o coração da atividade matemática. Por isso na escolha e adequação das questões isso foi considerado. A etapa III refere-se às interações. Realizar tarefa, promovendo diálogo entre os pares é um momento de aprendizado? Que benefícios podem ser observados a partir dessa alternativa de trabalho em sala de aula? Voltando ao papel do(a) professor(a): “é responsável por organizar as situações de maneira a garantir que cada estudante avance na construção do saber e que possa acessar esse saber nos diversos momentos em que necessite utilizá-lo" (ibidem, p. 16). É imprescindível que o professor assuma esse novo papel. Marineck (2001) trata dessa questão com muita propriedade ao elencar como o(a) professor(a) deve atuar nessa direção e propõe que ele(a) formule ou escolha cautelosamente os problemas que irá propor, para que os(as) estudantes, sintam-se impelidos(as) a agir, falar e refletir em busca de soluções. Na etapa III, optou-se por manter a mesma atividade da etapa anterior, para dar melhor visibilidade ao papel da interação, proposta desse estudo.

A partir das observações feitas nos quadros que representam cada etapa obtivemos os seguintes resultados para análise. 
Etapa I

\begin{tabular}{|c|c|c|c|c|c|c|c|c|}
\hline \multirow{2}{*}{ Participantes } & \multicolumn{7}{|c|}{ Resultados apresentados } \\
\cline { 2 - 10 } & \multicolumn{2}{|c|}{ Acertou } & \multicolumn{2}{|c|}{ Desistiu } & $\begin{array}{r}\text { Desistiu, mas } \\
\text { tentou }\end{array}$ & \multicolumn{2}{c|}{ Não acertou } \\
\cline { 2 - 10 } & Quant. & Porc. & Quant. & Porc. & Quant. & Porc. & Quant. & Porc. \\
\hline \multirow{2}{*}{ Ana Júlia } & 7 & $\mathbf{3 5 \%}$ & 8 & $\mathbf{4 0 \%}$ & 1 & $\mathbf{5 \%}$ & 4 & $\mathbf{2 0 \%}$ \\
\hline \multirow{2}{*}{ Pedro } & 3 & $\mathbf{1 5 \%}$ & 2 & $\mathbf{1 0 \%}$ & 4 & $\mathbf{2 0 \%}$ & 11 & $\mathbf{5 5 \%}$ \\
\hline
\end{tabular}

No quadro apresentado na Etapa I, vimos que tanto Ana Júlia quanto Pedro tiveram dificuldades em compreender os problemas/questões propostos. Das 20 questões apresentadas na atividade Ana Júlia conseguiu solucionar corretamente apenas $35 \%$. Entre as desistências e as questões incorretas somam-se as $65 \%$ questões restantes. Com relação a Pedro, temos que o número de questões incorretas e desistências, reúnem um total de $85 \%$, restando apenas $15 \%$ das questões resolvidas corretamente.

Considerando os princípios defendidos nos referenciais teóricos temos que destacar a importância de ensinar o processo de resolução de problemas seguindo os passos descritos. Para Dante (1995), um dos objetivos do ensino da matemática é propiciar ao estudante pensar de forma produtiva. Para isso é necessário que ele tenha em mãos situações que o desafiem e o motivem. Nesse sentido, ter ou não deficiência passa a ser um aspecto secundário da relação estabelecida no espaço de sala de aula.

Para encerrar essa considerações, parece adequado voltarmos ao que Araujo(2005) mencionou como um dos motivos que levam estudantes com essa característica a não conseguirem resolver problemas de ordem mais complexa em virtude da dificuldade em planejar e aplicar estratégias de solução; facilmente identificado nas questões que deixaram de resolver. Ambos apresentaram dificuldades, praticamente nas mesmas questões, de ordem mais complexas e com maior número de informação. Outro aspecto a ressaltar se refere à forma como se manifestam nas soluções dos problemas. De um modo geral as soluções apresentadas se restringiram meramente a cálculos mecânicos, utilizando as operações fundamentais. A que fugia desse padrão era deixada de lado. Por isso um grande número de desistência. Dante 
(1995) afirma que o mais importante é analisar o problema através dos procedimentos que levem a solução do que a resposta simplesmente. Pode-se concluir que uma atividade que tenha alternativas tende a chamar mais a atenção do(a) estudante para encontrar uma das respostas apresentadas do que envolvê-lo(a) na solução a partir das informações contidas no problema.

Etapa II - Atividade com adaptações

\begin{tabular}{|c|c|c|c|c|c|c|c|c|c|c|}
\hline \multirow{3}{*}{ Participantes } & \multicolumn{10}{|c|}{ Resultados apresentados } \\
\hline & \multicolumn{2}{|c|}{ Acertou } & \multicolumn{2}{|c|}{ Desistiu } & \multicolumn{2}{|c|}{$\begin{array}{c}\text { Desistiu, mas } \\
\text { tentou }\end{array}$} & \multicolumn{2}{|c|}{ Não acertou } & \multicolumn{2}{|c|}{$\begin{array}{l}\text { Acertou em } \\
\text { parte }\end{array}$} \\
\hline & Quant. & Porc. & Quant. & Porc. & Quant. & Porc. & Quant. & Porc. & Quant. & Porc. \\
\hline Ana Júlia & 3 & $30 \%$ & 5 & $50 \%$ & - & - & 2 & $20 \%$ & - & - \\
\hline Pedro & 3 & $30 \%$ & 2 & $20 \%$ & - & - & 4 & $40 \%$ & 1 & $10 \%$ \\
\hline
\end{tabular}

$\mathrm{Na}$ etapa anterior, os participantes levaram muito tempo para resolver a atividade proposta e demonstraram cansaço pela demora em sua conclusão. Além do fato de que algumas podiam ser fundidas por se tratar do mesmo assunto, como por exemplo, as questões 7, 8 e 13; 2 e 3. A partir daí foi eliminada metade das questões.

Observa-se no quadro, nessa etapa, que Ana Júlia desistiu ou errou $70 \%$ das questões apresentadas, obtendo êxito em apenas 30\% delas. Pedro também obteve a mesma porcentagem na quantidade de questões corretas, embora erros e acertos nem sempre coincidissem e Ana Júlia tenha demonstrado mais disposição para criar suas soluções, ainda que demoradas, como a que ela apresentou na questão $n^{\circ} 5$ (anexo VI). Como propõe os documentos que tratam de adequações (GDF, 2011), estas devem focalizar conteúdos, considerando a temporalidade, alterações nos objetivos, nas atividades e nas metodologias, visando atender às diferenças individuais. Para que esse processo seja bem sucedido é imprescindível que o(a) professor(a) conheça bem o(a) estudante e que seu foco não seja a deficiência que ele(a) apresenta. Relembrando o que aponta os documentos oficiais do GDF(2011) para facilitar a aprendizagem deve-se ter acolhimento e respeito ao ritmo e estilo de apreender, atividades em níveis de 
complexidade crescente, diversificação de metodologias. Por isso é importante que o(a) professor(a) tenha em mãos várias atividades diferenciadas, de forma que atenda as especificidades de cada um(a) - atividades em grupo, individuais, jogos, manipulação de objetos, atividades só de cálculos, atividades só com situações-problema, entre outros. O espaço da Sala de Recursos permite essas interferências e modificações; porém na sala de aula, com o(a) professor(a) regente, onde a maioria das atividades são propostas e realizadas, ele(a) precisa voltar seu olhar para essas questões.

Etapa III - Interação

\begin{tabular}{|c|c|c|c|c|c|c|c|c|c|c|}
\hline \multirow{3}{*}{ Participantes } & \multicolumn{10}{|c|}{ Resultados apresentados } \\
\hline & \multicolumn{2}{|c|}{ Acertaram } & \multicolumn{2}{|c|}{ Desistiram } & \multicolumn{2}{|c|}{$\begin{array}{l}\text { Desistiram, } \\
\text { mas tentaram }\end{array}$} & \multicolumn{2}{|c|}{ Não acertaram } & \multicolumn{2}{|c|}{$\begin{array}{c}\text { Acertaram em } \\
\text { parte }\end{array}$} \\
\hline & Quant. & Porc. & Quant. & Porc. & Quant. & Porc. & Quant. & Porc. & Quant. & Porc. \\
\hline $\begin{array}{c}\text { Ana Júlia } \\
\text { e } \\
\text { Pedro }\end{array}$ & 7 & $70 \%$ & 1 & $10 \%$ & - & - & - & - & 2 & $20 \%$ \\
\hline
\end{tabular}

A etapa final estabelecia que os participantes atuassem em conjunto.Nessa perspectiva vale relembrar a contribuição de Vigotski no que trata das interações na aprendizagem. Sabe-se que:

[...] vários pesquisadores estão enfatizando que esse novo olhar sobre o ensino da matemática não pode prescindir da ação interpessoal. Afirmam eles que é preciso criar na sala de aula uma "comunidade do saber". De fato, mesmo que o raciocínio contextualizado se desenvolva no praticante em situação de resolução de problemas, é conveniente examinar como sua elaboração depende igualmente da criação de "comunidades de trocas", ou seja, de grupos de pares envolvidos na resolução de tarefas matemáticas (Mellin-Olsen 1986; Janvier 1991). Um professor de matemática e pesquisador chega mesmo a argumentar que grande parte da aversão que os alunos têm à disciplina poderia ser vencida com a criação de tais comunidades (STODOLSKY, 1985, apud Moysés, 1997, p. 79). 
É isso que é proposto discutir nesse estágio.

Ao apresentar a atividade aos participantes, os mesmos foram orientados, da importância em compartilhar seus conhecimentos, numa ajuda mútua. Ambos erraram inicialmente, e individualmente, algumas questões; mas após a realização em conjunto chegaram ao resultado correto. Conforme está representado no quadro, $70 \%$ do total de questões foram resolvidas corretamente, desistiram de $10 \%$ delas e $20 \%$ dessas questões estavam certas, em parte. Embora tenham utilizado muito tempo na realização dessa atividade, o envolvimento dos participantes foi maior, tornando a aprendizagem mais rica e significativa para cada um deles. Arrisca-se dizer, apesar dos poucos elementos apresentados nesse estudo, que estes resultados comprovam a relevância das interações no processo de aprendizagem. "Numa atividade coletiva, ou sob a orientação de adultos, [....] as crianças são capazes de fazer muito mais coisas"(Vigotski, 2007, p. 101). Essa mesma fonte apresenta algumas considerações relevantes nessa análise final. Há muito tempo acreditava-se que, por meio de testes, pode-se estabelecer o nível de desenvolvimento mental, cujo processo educacional deveria se basear sem ultrapassálos. Tal procedimento norteava o aprendizado em direção a estágios já completados. Ponto de vista que apresenta erro no que diz respeito ao ensino de estudantes com deficiência intelectual. A idéia original considerava que o ensino para esses estudantes deveria basear-se somente no concreto, eliminando tudo que está associado ao pensamento abstrato. Foi uma falha, pois restringiu o pensamento a questões concretas, além de impedir a superação das dificuldades que esses(as) estudantes apresentavam, como se estivessem condenados a aprender de um único jeito. Será que reproduzimos ainda esse pensamento? O que estamos reproduzindo em sala de aula? Quanto se acredita na capacidade desses(as) estudantes? Que condições são ofertadas para que avancem? Que discussões são realizadas no espaço pedagógico da escola que permita encontrar alternativas para o sucesso desses(as) estudantes? Cabe uma pausa do leitor para uma reflexão... . 


\section{CONSIDERAÇÕES FINAIS}

O homem não está restrito a simples reflexos estímulo-respostas. Ele consegue estabelecer conexões indiretas entre as estimulações que recebe e as respostas que emite por meio de vários elos de mediação. Quando se introduz uma modificação no ambiente através de seu próprio comportamento, essa modificação vai influenciar seu comportamento futuro. Luria e Vigotski aplicam o conceito de mediação quase que exclusivamente aos processos de desenvolvimento mental da criança, especialmente ao discutir o papel da linguagem e do desenvolvimento. Enfatizam a idéia de que o desenvolvimento mental da criança deve ser visto como processo histórico no qual o ambiente social e o não social da criança induzem o desenvolvimento do processo de mediação de várias funções mentais superiores ${ }^{52}$.

As ações propostas proporcionaram algumas reflexões acerca do que foi apresentado até aqui no referencial teórico, considerando alguns aspectos que foram relevantes nesse estudo. Além das interações, das adequações curriculares que são propostas em lei, não se deve deixar de mencionar a importância dos estudos apresentados nos tópicos relacionados à matemática, dada a sua importância dentro de um contexto onde se espera cidadãos mais atuantes frente aos desafios da sociedade atual. Excluir àqueles que apresentam alguma necessidade especial, seria negar um novo contexto de sociedade e de educação que busca minimizar preconceitos, respeitando as diferenças.

No bojo das reflexões aqui desenvolvidas, ressalta-se que Vigotski teve uma importância significativa nesse estudo; visto o valor que a interação entre pares tem na busca para encontrar alternativas pedagógicas que proporcionem aos estudantes com necessidades educacionais especiais, atendidos em Sala de Recursos, uma aprendizagem que lhes seja de fato significativa. Fávero (2003, apud. SANTANA, 2010), aponta que as intervenções do(a) professora(a) precisam se basear em dois eixos: considerar o

\footnotetext{
${ }^{52}$ Fragmento do livro Desenvolvimento Cognitivo, seus fundamentos culturais e sociais, extraído da obra Vigotski, L.S.; Luria, A. R.; Leontiev, A. N. Linguagem, desenvolvimento e aprendizagem , (2010) em suas páginas finais.
} 
desenvolvimento do sujeito com deficiência e suas particularidades, bem como propor um método investigativo que atente para a atividade mediada.

Enfim, as ideias arroladas apontam para a necessidade de rever conceitos e maneiras de lidar com o ensinar e o aprender no ambiente escolar. As adequações curriculares nesse contexto escolar possibilitam também uma reflexão acerca da ação do(a) professor(a) no seu espaço pedagógico. Visam facilitar a vida acadêmica daqueles que, por algum motivo não têm as mesmas condições de aprendizagem que outros, considerados pelo sistema como "normais". Por meio dessas adequações surgiram algumas sugestões de encaminhamentos criadas pela pesquisadora a partir das observações e referenciais que acompanharam esse estudo.

- Disponibilizar um tempo maior para a realização das atividades ou diminuição das mesmas a partir de objetivos mais claros;

- $\quad$ Elaborar um vocabulário mais apropriado para a série. Diante do diálogo dos dois participantes foi possível identificar que a comunicação entre os pares é diferente e muitas vezes os problemas não são resolvidos por inadequação do vocabulário;

- Realizar algumas atividades em sala de aula entre pares;

- Separar um tempo de aula e sentar com alguns(as) estudantes, individualmente, para que se conheça melhor o seu "pensamento matemático";

- $\quad$ Evitar questões com alternativas. Foi observado que os(as) estudantes se utilizam dos valores apresentados na resposta para resolver os problemas e exercícios propostos. Partem da resposta e não da situação apresentada;

- Modificar a ordem das questões de maneira que sejam organizadas conforme o grau de dificuldade, do mais simples ao mais complexo.

- $\quad$ Construir enunciados mais breves;

- Fazer uma correção diferenciada, de forma a aproveitar o máximo de informações dadas pelo(a) estudante nas suas soluções. Considerar uma questão correta parcialmente pode estabelecer uma relação diferente entre o processo de ensinar e aprender.Valoriza-se assim, o que o(a) estudante pensa e não apenas os resultados numéricos que ele(a) apresenta, humanizando mais essa relação;

- Não acumular conteúdos pode ser uma boa alternativa, criando outras possibilidades de avaliação no ambiente escolar; 
- Realizar uma atividade oral, sempre que possível. Isso possibilita conhecer melhor as possibilidades e potencialidades desses(as) estudantes.

Pelo exposto e a partir dos resultados apresentados na pesquisa, pode-se concluir a necessidade de mudar as estratégias de intervenção pedagógica, para que caminhem na direção da aprendizagem dos(as) estudantes com necessidades especiais. Nesse sentido, pôde-se observar que a parceria construída na realização da atividade proporcionou, além do sucesso nas soluções das questões, a troca de experiências e conhecimentos. Embora a escola, para Rego (2009) apresente atividades educativas diferentes daquelas que são vivenciadas no cotidiano, por serem mais sistemáticas, tem como obrigação tornar o conhecimento mais acessível formalmente organizado. "Nesse contexto as crianças são desafiadas a entender as bases dos sistemas de concepções científicas e a tomar consciência de seus próprios processos mentais" (idem, p. 104). O diálogo e a atividade mediada são imprescindíveis nessa nova construção. Conforme aponta o mesmo autor, nessa mesma obra (p. 106):

\footnotetext{
O ensino verbalista, baseado na transmissão oral de conhecimentos por parte do professor, assim como as práticas espontaneístas, que abdicam de seu papel de desafiar e intervir no processo de apropriação de conhecimentos por parte das crianças e adolescentes, são, na perspectiva vygotskiana, além de infrutíferos, extremamente inadequados. Seus postulados apontam para a necessidade de criação de melhores condições na escola, para que todos os alunos (grifo nosso) tenham acesso às informações e experiências e possam efetivamente aprender.
}

Ao tratar dessa relação aula-prefessor-estudante, tem que se ponderar que as atividades que são desenvolvidas na Sala de Recursos não garantem o sucesso desses(as) estudantes, considerando que esse é um espaço diferenciado de estudo. Porém, possibilita encontrar alternativas pedagógicas que auxiliem estudantes com necessidades especiais na aprendizagem matemática. O que se defende, portanto, é uma articulação melhor entre esse espaço pedagógico e a sala de aula regular. Parece que as duas andam na contramão o tempo todo, tendo em vista que a Sala de Recursos é concebida por muitos como espaço para aula de reforço, onde quase sempre são reproduzidas as ações que são desenvolvidas pelos(as) professores regentes. Como o olhar desse(a) especialista está voltado o tempo todo para tornar acessível o que a escola ensina, a parceria desses profissionais é fundamental. Nesse contexto seria 
interessante redimensionar o valor das interações sociais que permeia o ambiente escolar: estudantes $\Leftrightarrow$ professores em processo de diálogo constante. Para isso é necessária uma disposição do(a) professor(a) em conhecer melhor esse(a) estudante. Rego(2009), propõe que ele(a) conheça as suas descobertas, hipóteses, informações, crenças, opiniões e suas teorias acerca do mundo que o(a) rodeia de que forma interagem, principais dúvidas e dificuldades.

Finalmente, cabe refletir também sobre o papel da escola na perspectiva da educação inclusiva. Inclusão é um processo de acolhimento. Na escola deve-se preparar o futuro adulto para conviver de forma harmônica com o outro, vencer barreiras e preconceitos e tornar possível a aprendizagem daqueles que culturalmente falando, são estigmatizados pelo fracasso escolar. Cabe refletir que modelo de escola seria necessário para promover o sucesso acadêmico desses(as) estudantes? Pôde-se perceber nesse estudo que realizar adequações curriculares em seus diversos aspectos torna essa aprendizagem possível. É necessário traçar, portanto, objetivos claros para cada atividade num diálogo reflexivo a partir das seguintes perguntas: $\mathrm{O}$ que se pretende com esse problema? O que o(a) estudante deve saber nessa atividade que é significativo? O que pode ser deixado para etapa posterior? Que grau de dificuldade pode ser apresentado nessa situação-problema? Que saberes esse(a) estudante já possui sobre o assunto? É assunto da sua vida diária? Como estabelecer a relação entre o conhecimento espontâneo e científico? Como organizar o espaço de sala de aula para proporcionar a interação entre os pares e de que maneira ela será constituída? Que papel o(a) professor(a) desempenha nessa nova ação?

Deixam-se aqui essas indagações, para que possam de alguma forma promover um minuto de reflexão acerca dessa nova organização escolar que propõe a todos o direito de aprender, independente de suas particularidades, mas levando em conta essas diferenças e o seu potencial.

Não há receita que dê conta de resolver todos os problemas que aparecem no ambiente escolar. Lida-se com pessoas o tempo todo. Pessoas que se desenvolvem, compartilham suas experiências, mudam os rumos da sua história. Aprendemos lições, compartilhamos ideias, projetos, conhecimentos. Essa interação existe independente de nossa vontade. Viver socialmente é uma condição de SER. Não se pode deixar que a escola navegue em outra direção. As experiências compartilhadas movem nossas relações e a escola é um ambiente favorável ao crescimento intelectual e transformador de pessoas e não se deve perder isso de vista. 


\section{REFERÊNCIA BIBLIOGRÁFICA}

ABREU, Maria Cristina Barreto Fernandes. Desenvolvimento de conceitos científicos em crianças com deficiência mental. Dissertação (Mestrado em Psicologia). Universidade Católica de Brasília, DF. 2006.

ARAÚJO, Sandra Lúcia Silvia. O processo de solução de problemas em crianças com deficiência mental leve: a relação entre o real e o virtual. Revista Brasileira de Educação Especial. V. II. N 3. São Paulo. 2005, p. 321-466.

CAMPOS, Tânia M. M.; NUNES, Terezinha. Tendências atuais do ensino e aprendizagem da matemática. Em aberto, Brasília, ano 14, nº 62, abr/jun. 1994. Disponível em: <www.rbep.inep.gov.br/index.php/emaberto/article/view/928/833>. Acesso em 14 mar. 2011.

CESMAC. Revista Científica de Psicologia. Maceió. Brasil. Ano I, $n^{\circ} 1$ - julho de 2007.

COLLARES, Cecília Azevedo; MOYSÉS, Maria Aparecida Affonso. A transformação do espaço pedagógico em espaço clínico (a patologização da educação). Série Ideias $\mathrm{n}^{\mathrm{0}}$ 23. São Paulo. FDE, 1994. Disponível em <www.crmariocovas.sp.gov.br/amb_a.php?t=008>. Acesso em: 19 mar. 2011.

D’AMBRÓSIO, Ubiratan et al; FONSECA, Maria da Conceição Ferreira Reis (org.). Letramento no Brasil: Habilidades matemáticas. São Paulo, Global, 2004.

DANTE, Roberto Luiz. Didática da resolução de problemas de matemática. $7^{\text {a }}$ edição. Editora Ática S.A. São Paulo, 1995.

GIANCATERINO, Roberto. A matemática sem rituais. Rio de Janeiro: Walk Ed., 2009. 
GDF, Currículo da Educação Básica - Educação de Jovens e Adultos. SEE/DF, Brasília, 2011. Versão Experimental. DODF, Seção 1-123, 29 de junho de 2009, p. 5.

GDF, Orientação Pedagógica. Educação Especial. SEE/DF, Brasília, DF, 2010.

KELMAN, Celeste Azulay. Sociedade, educação e cultura. In: MACIEL, Diva Albuquerque; BARBATO, Silviane (orgs.). Desenvolvimento Humano, Educação e Inclusão Escolar. Brasília: Editora UNB, 2010.

LOPES, Martins; MORILLAS. Interação entre aprendizado e desenvolvimento. In: Cole, Michael et al. (orgs). VIGOTSK L. S. A Formação Social da Mente: o desenvolvimento dos processos psicológicos superiores. $7^{\text {a }}$ edição. São Paulo: Martins Fontes, 2007.

LURIA, Alexander R. O domínio sobre a memória e o pensamento. In: Cole, Michael et al. (orgs). VIGOTSKI, L. S. A Formação Social da Mente: o desenvolvimento dos processos psicológicos superiores. $7^{\text {a }}$ edição. São Paulo: Martins Fontes, 2007.

MACIEL, Diva Albuquerque; RAPOSO, Mírian Barbosa Tavares. Metodologia e construção do conhecimento: atribuições para o estudo da inclusão. In: MACIEL, Diva Albuquerque; BARBATO, Silviane (Orgs.). Desenvolvimento Humano, Educação e Inclusão Escolar. Brasília: Editora UNB, 2010.

MANTOAN, Maria Teresa Egler; PRIETO, Rosângela Gavioli. Inclusão escolar: pontos e contrapontos. São Paulo: Summus, 2006.

MARCIANO, Lilian Ceile. As crianças resolvem problemas para aprender matemática. In: MARINCEK, Vania. Aprender matemática resolvendo problema. Porto alegre. Artmed Editora, 2001.

MARINCEK, Vania. Aprender matemática resolvendo problema. Porto alegre. Artmed Editora, 2001. 
MARTINS, João Carlos. Vygotsky e o papel das interações sociais na sala de aula: reconhecer e desvendar o mundo. Série ideias no 28. São Paulo. FDE. 1997, p. 111122. Disponível em: < www.crmiocovas.sp.gov.br/ideias>. Acesso em: 10 mar. 2011.

MELO, Gabriela Sousa. Diálogos com profissionais do ensino especial. O contexto histórico-cultural e suas repercussões na prática educacional do Distrito Federal. Dissertação de Mestrado. Instituto de Psicologia. 2003. Brasília. UNB.

MIETO, Gabriela; RIBEIRO, Julia C. Coelho; SILVA, Daniele N. Henrique. O aluno com deficiência intelectual na sala de aula. In: MACIEL, Diva Albuquerque; BARBATO, Silviane (Orgs.). Desenvolvimento Humano, Educação e Inclusão Escolar. Brasília: Editora UNB, 2010.

MINAYO, Cecília de Sousa (org.). Pesquisa Social Teoria, método e criatividade. 23. Ed. Petrópolis. Vozes, 2004.

MOYSÉS, Lúcia. Aplicações de Vygotsky à educação matemática. 9a edição. São Paulo. Papirus, 1997.

Nova Escola. Inclusão. Educação Especial. Atendimento educacional especializado. Deficiência Mental. Edição 223. 2009.

NUNES, Terezinha; BRYANT, Peter. Crianças fazendo matemática. Tradução Costa, Sandra. Porto Alegre. Artes Médicas, 1997.

PADILHA, Anna Maria Lunardi. Práticas educativas: perspectivas que se abrem para a Educação Especial. Educação \& Sociedade. Vol. 21. № 71. Campinas, julho. 2000 .

RAIÇA, Darcy; PRIOSTE, Claúdia; MACHADO, Maria L. Gomes. Dez questões sobre a educação inclusiva da pessoa com deficiência mental. São Paulo. Avercamp, 2006 . 
REGO, Teresa Cristina. Vygotsky: uma perspectiva histórico-cultural da educação. 20. Ed. RJ. Vozes, 2009.

REY, Fernando Luiz González. Resenha do livro Pesquisa qualitativa: caminhos e desafios. Revista Científica de Psicologia. Coordenação Pedagógica do Curso de Psicologia do

VIGOTSKI, L. S. Pensamento e Linguagem. Tradução: CAMARGO, Jefferson Luiz. $2^{a}$ edição. São Paulo. Martins Fontes, 1998.

VIGOTSKI, Lev Semenovich; LURIA, Alexander Romanovich; LEONTIEV, Alexis N. Linguagem, desenvolvimento e aprendizagem. 11 a edição. São Paulo. Ícone, 2010. 
A N EXOS 


\section{ANEXO I}

\section{A TRANSFORMAÇÃO DO ESPAÇO PEDAGÓGICO EM ESPAÇO CLÍNICO}

\section{(A PATOLOGIZAÇÃO DA EDUCAÇÃO)}

\section{Cecília Azevedo Lima Collares(1)}

Maria Aparecida Affonso Moysés(2)

O termo medicalização refere-se ao processo de transformar questões nãomédicas, eminentemente de origem social e política, em questões médicas, isto é, tentar encontrar no campo médico as causas e soluções para problemas dessa natureza. A medicalização ocorre segundo uma concepção de ciência médica que discute o processo saúde-doença como centrado no indivíduo, privilegiando a abordagem biológica, organicista. Daí as questões medicalizadas serem apresentadas como problemas individuais, perdendo sua determinação coletiva. Omite-se que o processo saúde-doença é determinado pela inserção social do indivíduo, sendo, ao mesmo tempo, a expressão do individual e do coletivo. Um exemplo gritante de como se medicalizam as grandes questões sociais constitui o próprio processo saúde-doença, que vem sendo transformado em um problema médico, referente a cada indivíduo em particular.

1 Professora Doutora no Depto. de Psicologia Educacional da Faculdade de Educação da Unicamp.

2 Professora Doutora no Depto. de Pediatria da Faculdade de Ciências Médicas da Unicamp.

Esse processo de medicalização ocorre em escala crescente nas sociedades ocidentais e, na maior parte das vezes, representa a pura biologização de conflitos sociais. Como elemento final comum recorre-se ao reducionismo biológico, segundo o qual a situação de vida e o destino de indivíduos e grupos poderiam ser explicados por e reduzidos a - características individuais. Por essa visão de mundo, as circunstâncias sociais, políticas, econômicas, históricas teriam mínima influência sobre a vida das pessoas; daí decorre que o indivíduo seria o maior responsável por seu destino, por sua condição de vida, por sua inserção na sociedade. O sistema sociopolítico é praticamente desresponsabilizado, em uma concepção funcionalista bastante bem-elaborada e 
eficiente. Eficiente a ponto de terminar pela culpabilização da vítima, segundo RYAN (1976), e de conseguir que a própria vítima se considere culpada!

A biologização da sociedade só consegue se difundir tão rapidamente, e ser tão facilmente aceita, por trazerem si a mesma ideologia que permeia todo o sistema de preconceitos que opera na vida cotidiana de cada homem. Então, é incorporada a esse sistema com grande facilidade, sem conflitos ideológicos -ao contrário, resistir a ela gera conflitos -, e infiltra-se no "bom-senso", no "senso comum", termos usualmente empregados para nomear/escamotear esse sistema de preconceitos no qual opera o pensamento do homem em sua vida de todo dia.

A Educação, assim como todas as áreas sociais, vem sendo medicalizada em grande velocidade, destacando-se o fracasso escolar e seu reverso, a aprendizagem, como objetos essenciais desse processo. A aprendizagem e a não-aprendizagem sempre são relatadas como algo individual, inerente ao aluno, um elemento meio mágico, ao qual o professor não tem acesso - portanto, também não tem responsabilidade. Ante índices de 50,70\% de fracasso entre os alunos matriculados na $1^{\mathrm{a}}$ série da Rede Pública de Ensino brasileira, o diagnóstico é centrado no aluno, chegando no máximo até sua família; a instituição escolar, a política educacional raramente são questionadas no cotidiano da Escola. Aparentemente, o processo ensino-aprendizagem iria muito bem, não fossem os problemas existentes nos que aprendem.

Até alguns anos atrás, a biologização da Educação era feita basicamente pela ciência médica, concretizada pelos profissionais médicos, atuando tanto na Rede Pública de Saúde, como em consultórios particulares e, principalmente, nas faculdades. Dessa circunstância advém o termo medicalização para nomear essa prática. Entretanto, mais recentemente, com a criação/ampliação de campos do conhecimento, novas áreas, com seus respectivos profissionais, estão envolvidas nesse processo. São psicólogos, fonoaudiólogos, enfermeiros, psicopedagogos que se vêm aliar aos médicos em sua prática biologizante. Daí a substituição do termo medicalização por um outro mais abrangente - patologização -, uma vez que o fenômeno tem-se ampliado, fugindo dos limites da prática médica.

De que maneira ocorre a patologização do fracasso escolar? Basicamente sob duas vertentes:

- O fracasso escolar seria uma conseqüência da desnutrição; obviamente, essa apresentação só ocorre para as crianças da classe trabalhadora. 
- O fracasso escolar seria o resultado da existência de disfunções neurológicas, incluindo-se aqui a hiperatividade, a disfunção cerebral mínima, os distúrbios de aprendizagem, a dislexia; inicialmente essa forma restringia-se às crianças das classes média e alta, porém, atualmente, está disseminada inclusive entre a classe trabalhadora, criando uma situação no mínimo esdrúxula - uma mesma criança ser rotulada de deficiente mental por desnutrição e de disléxica. A relação entre desnutrição e fracasso escolar já foi objeto de muitos trabalhos científicos. Sinteticamente, podem-se recolocar os pontos fundamentais para esta discussão. A controvérsia sobre a influência da desnutrição no desenvolvimento cognitivo refere-se à desnutrição grave, de terceiro grau, que ocorra por um longo período no início da vida, quando o sistema nervoso central está-se desenvolvendo. É consenso entre os autores que se dedicam a estudar o assunto, adotando os preceitos mínimos do método científico, que formas mais leves de desnutrição não têm qualquer repercussão sobre o sistema nervoso central, mesmo em termos de anatomia. Essa controvérsia ocorre pela impossibilidade metodológica de se isolar a desnutrição de seus determinantes sociais e econômicos, aliada ao fato de que tais determinantes são os mesmos que devem ser considerados quando se fala em desenvolvimento cognitivo. Admite-se, hoje, que a desnutrição grave, no início da vida e de longa duração, pode interferir no desenvolvimento das funções intelectuais superiores mais complexas do ser humano, principalmente o raciocínio abstrato superior. Estas funções, as mais complexas e sofisticadas do homem, sem dúvida, nem ao menos estão desenvolvidas aos sete anos de vida; portanto, não podem constituir substrato necessário para a alfabetização. A afirmação de que a desnutrição é uma causa importante do fracasso escolar incorre em dois vieses metodológicos:

- As crianças matriculadas na Rede Pública de Ensino são portadoras de desnutrição leve, de primeiro grau, portanto sem alterações no cérebro.

- Está-se falando em alfabetização, processo de aprendizagem que obviamente necessita de funções intelectuais superiores, porém não as mais complexas; ante o potencial cognitivo do ser humano, pode-se mesmo considerar que o processo de alfabetização é relativamente simples para o homem. Entretanto, é importante enfatizar que, diferentemente do que se afirma muitas vezes na Universidade, a desnutrição ainda persiste como uma das principais causas do fracasso escolar no discurso e nas ações dos professores. Discutirem profundidade cada uma destas duas formas de apresentação de um mesmo processo ideológico foge aos objetivos deste texto e, para tanto, remetemos a outros trabalhos de nossa autoria, já publicados e listados na bibliografia apresentada 
ao final deste texto. Em pesquisa recente, desenvolvida por nós na Rede Municipal de Ensino de Campinas, entrevistando diretores e professores sobre quais seriam as causas do fracasso escolar, encontram-se algumas falas que ilustram nossas afirmações anteriores.

Com a palavra, professores e diretores:

"Fisicamente a Eliana é magérrima (...) tem cabelo ralo, tem manchas nos braços e pernas (...) o pior é que a mãe tem uma aparência ótima. É a subnutrição. A Daniela também é subnutrida, é magrinha, muito enjoada, nunca come a merenda (...). Mas a subnutrição na Carla é mais gritante. Com subnutrição não dá mesmo para aprender $(\ldots) "$

"A Juliana é o seguinte: a mãe é separada do pai, a mãe tem paralisia, eles passam fome, são desnutridos mesmo. Não conseguem por isso aprender. Não sei o que seria aconselhável, médico ou psicólogo?"

"(...) Causas do não-aprender? Bem.., é a alimentação... problemas em casa... A gente vê logo que é desnutrida. Se ela é mal-alimentada, a cabecinha não pode mesmo funcionar. No geral é o organismo todo que está comprometido, tem problema neurológico por causa da desnutrição (...)"

A incorporação da crença de que a desnutrição é responsável pelo fracasso escolar ao sistema de preconceitos pode ser evidenciada no fato de que, como resultado de reciclagens, cursos de extensão, o discurso das professoras se modifica, se moderniza; a patologização passa a ocorrer sob novas formas, de acordo com as circunstâncias, com a "moda". Porém, quando se permite que esse novo discurso se estenda, quando se pergunta um pouco mais, aparece o mesmo velho discurso:

"(...) ela não consegue mesmo aprender é pré-silábica (...) ela é imatura, desnutrida (...)".

Os mitos, as crenças resistem inabalavelmente ao confronto com a realidade. No máximo, transmutam-se em aparentes novos mitos, novas crenças, para permanecerem exatamente iguais. A outra maneira de se patologizar a não-aprendizagem consiste nas disfunções neurológicas, sendo os distúrbios de aprendizagem sua forma de expressão mais em nenhuma destas crianças era desnutrida ao exame clínico. Moda atualmente. Sobre este assunto, podemos afirmar que até hoje, cem anos depois de terem sido aventados pela primeira vez por um oftalmologista inglês, não se provou sua existência. É uma longa trajetória de mitos, estórias criadas, fatos reais que são perdidos/omitidos... Trata-se de uma pretensa doença neurológica jamais comprovada; inexistem critérios 
diagnósticos claros e precisos como exige a própria ciência neurológica; o conceito é vago demais, abrangente demais...

Como diferenciar uma criança disléxica de uma mal-alfabetizada? Esse é um dos pontos centrais da discussão. Para esse grupo de pretensas patologias, a única coisa precisa é a necessidade de longos e caros tratamentos em clínicas de distúrbios de aprendizagem. A proliferação dessas clínicas é um ótimo indicador da freqüência crescente com que esse "diagnóstico" tem sido feito. A patologização da aprendizagem constitui um processo em expansão, que se dissemina rapidamente, com grande aceitação geral. Os pais das crianças reagem a seus resultados como se a uma fatalidade. Para os professores, representa um desviador de responsabilidades - "Eu faço o que posso, mas eles não aprendem: A instituição escolar, parte integrante do sistema sociopolítico, legitima suas ações e suas não-ações, pois o problema decorreria de doenças que impedem a criança de aprender. A difusão acrílica e crescente de "patologias" que provocariam o fracasso escolar- de modo geral, "patologias" mal definidas, com critérios diagnósticos vagos e imprecisos têm levado, de um lado, à rotulação de crianças absolutamente normais e, de outro, a uma desvalorização crescente do professor, cada vez menos apto a lidar com tantas "patologias" e "distúrbios". A criança estigmatizada incorpora os rótulos, introjeta a doença. Passa a ser psicologicamente uma criança doente, com conseqüências previsíveis sobre sua autoestima, sobre seu autoconceito e, aí sim, sobre sua aprendizagem. Na prática, ela confirma o diagnóstico/rótulo estabelecidos.Uma outra agravante decorre do fato de que parece que a única preocupação consiste em encontrar "diagnósticos" que expliquem, justifiquem o não-aprender. Não se trata de buscar um diagnóstico real para uma ação efetiva, no sentido de minimizá-lo, ou mesmo anulá-lo. Uma vez feito o "diagnóstico", cessam as preocupações e angústias... Uma professora de $1^{\text {a }}$ série em uma Escola em Campinas encaminhou dez crianças (de uma classe com 31 alunos) para serem avaliadas por profissionais do Serviço de Saúde Mental; dessas, três foram triadas para um tratamento com a psicopedagoga do serviço, porém ficaram aguardando vagas. A partir daí, a professora, mais tranqüila, só se refere a esses alunos como os DMs (Deficientes Mentais):

"Os três com DM estão esperando a vaga, mas não sei quando (...) continuam comigo, mas não fazem nada (...)". 
Quando indagada se não gostaria que alguém esclarecesse o que estaria acontecendo com eles e se não achava que, no caso, a psicóloga deveria dar-lhe algum tipo de orientação, respondeu:

(...) eu não sei... elas são muito ocupadas lá também, elas têm crianças lá que não dão conta de atender, então ela já fez o teste e já foi aprovado e ela disse que agora tem que esperar a vaga na Saúde Mental, só isso... ".

Infelizmente, deve-se ressaltar que este não é um episódio isolado. É muito comum profissionais tanto da Educação como da Saúde quase que se contentarem com um "diagnóstico". A busca por tratamento eficaz, por soluções efetivas, bem, isso já é uma outra história...

Do outro lado da moeda, os professores, que deveriam ser também os responsáveis por analisar e resolver problemas educacionais, assumem uma postura acrílica e permeável a tudo; transformam-se em mediadores, apenas triando e encaminhando as crianças para os especialistas da Saúde. Essa prática acalma a angústia dos professores, não só por transferir responsabilidades, mas principalmente porque desloca o eixo de preocupações do coletivo para o particular. O que deveria ser objeto de reflexão e mudança - o processo pedagógico - fica mascarado, ocultado pelo diagnosticar e tratar singularizados, uma vez que o "mal" está sempre localizado no aluno. E o fim do processo é a culpabilização da vítima e a persistência de um sistema educacional perverso, com alta eficiência ideológica. Voltemos a ouvir os professores...

"A OP sugeriu que separássemos os alunos que apresentam dificuldades para aprender para que o psicólogo pudesse fazer o diagnóstico..."

"Tem criança que desde o primeiro mês percebi que não ia. Tem criança doente na classe; tem criança com baixo peso, tem a que não enxerga, tem aquelas que não têm coordenação motora e tudo isto interfere no aprendizado. No começo do ano já tinha alunos que por mais que eu fizesse, por mais que eu me esforçasse, que desse de mim, eles não iam. E vão repetir mesmo."

"As crianças se interessam em ler, até brigam por causa de livrinhos, mas as lições da lousa, 'separe silabas' ou 'forme frases', levam mais de meia hora para fazer... são muito lentas..."

Com isto, o espaço eminentemente pedagógico da instituição escolar tem-se esvaziado, tem-se tornado vago. Uma instituição social em que seus atores - os profissionais da Educação -, rebaixados na escala social, com salários aviltantes, sentindo-se incapazes, expropriados de seu saber, estão prontos a delegar seu espaço, 
prontos a submeterem-se a uma nova ordem. O trabalho pedagógico, desqualificado, cede terreno para o trabalho de outros profissionais, estimulados pela necessidade de mercado de trabalho. O espaço escolar, voltado para a aprendizagem, para a normalidade, para o saudável, transforma-se em espaço clínico, voltado para os erros e distúrbios. Sem qualquer melhoria dos índices de fracasso escolar... Porém, se as crianças continuam não aprendendo, a isto agrega-se, em taxas alarmantes, a incorporação da doença... uma doença inexistente...

Bibliografia

COLLARES, C. A. L., MOYSÉS, M. A. A. Educação ou saúde? Educação X saúde? Educação e saúde! Cadernos Cedes, São Paulo: Cortez/Cedes, n. 15, 1985.

MOYSÉS, M. A. A., LIMA, G. Z. Desnutrição e fracasso escolar: uma relação tão simples? Ande, n. 5, p. 57, 1982.

MOYSÉS, M. A. A., COLLARES, C. A. L. Sobre alguns preconceitos no cotidiano escolar. In: Alfabetização: passado, presente, futuro. São Paulo: FDE, 1993. p. 9-25. (Série Idéias, 19).

. A história não contada dos distúrbios de aprendizagem. Cadernos Cedes, Campinas: Papirus/Cedes, n. 28, 1992.

RYAN, W. Blaming the victim. New York: Vintage Books Edition, 1976. 


\section{ANEXO II}

FICHA DE REGISTRO DE ADEQUAÇÃO CURRICULAR ${ }^{53}-$ modelo $^{54}$

\section{Identificação do aluno}

\begin{tabular}{|l|l|}
\hline Nome completo do aluno: & Série/turma/turno: \\
\hline Data de Nascimento: & Escola Atual: \\
\hline Tipo de deficiência/Diagnóstico do aluno: & \\
\hline Filiação: & $\begin{array}{c}\text { Período de vigência das } \\
\text { adequações: }\end{array}$ \\
\hline Endereço: & \\
\hline Telefone: &
\end{tabular}

2. Descrição sucinta sobre a escolarização do aluno

a) Perfil do aluno

b) Tipos de apoio recebidos no passado e atualmente (Ex.: Atividades esportivas, atendimento psicopedagógico, equoterapia)

c) Descrição suscinta sobre atendimentos terapêuticos e ou clínicos recebidos no passado e atualmente (fonoaudiologia, oftalmologia, psicoterapia, fisioterapia, terapia ocupacional, neurologia, psiquiatria)

53 Autores: Nara Liana Pereira-Silva, Giselda B. Jordão de Carvalho, Márcia Silveira da Costa Benetti, Márcia Cabral dos Santos \& Márcia Cristina Lima Pereira.

${ }^{54} \mathrm{O}$ modelo apresentado é uma adaptação do original, criado por uma Regional de Ensino do DF, em reunião de Sala de Recursos com toda a equipe. 
4. Sugestões para melhorias no processo de aprendizagem do aluno nos contextos:

\begin{tabular}{|l|l|}
\hline \multirow{2}{*}{ ESCOLAR } & \\
\cline { 2 - 2 } & \\
\hline \multirow{2}{*}{ FAMILIAR } & \\
\cline { 2 - 2 } & \\
\hline \multirow{2}{*}{ OUTROS } & \\
\cline { 2 - 2 } & \\
\hline
\end{tabular}

\section{Encaminhamentos /Observações}

\begin{tabular}{|c|c|c|c|}
\hline Disciplina & Nome do professor & Assinatura & Matrícula \\
\hline 1. Português & & & \\
\hline 2. Inglês & & & \\
\hline 3. Ed. Física & & & \\
\hline 4. Artes & & & \\
\hline 5. Matemática & & & \\
\hline 6. Biologia & & & \\
\hline 7. Química & & & \\
\hline 8. Física & & & \\
\hline 9. História & & & \\
\hline 10. Geografia & & & \\
\hline 11. Sociologia & & & \\
\hline 12. Filosofia & & & \\
\hline 13. PD & & & \\
\hline 14. PD & & & \\
\hline 15. PD & & & \\
\hline
\end{tabular}

\begin{tabular}{|l|l|l|l|l|}
\hline \multicolumn{5}{|c|}{ PROFESSORES SUBSTITUTOS } \\
\hline \multicolumn{1}{|c|}{ Disciplina } & PERÍODO & Nome do professor & Assinatura & Matrícula \\
\hline 1. & & & & \\
\hline 2. & & & & \\
\hline 3. & & & & \\
\hline 4. & & & & \\
\hline 5. & & & & \\
\hline
\end{tabular}


PROFESSOR (A) DE ATIVIDADES:

\begin{tabular}{|l|l|l|l|}
\hline \multicolumn{4}{|c|}{ SALA DE RECURSOS } \\
\hline \multicolumn{1}{|c|}{ Disciplina } & Nome do professor & \multicolumn{1}{c|}{ Assinatura } & Matrícula \\
\hline $\begin{array}{l}\text { 1. Códigos e } \\
\text { Linguagens }\end{array}$ & & & \\
\hline $\begin{array}{l}\text { 2. Ciências da } \\
\text { Natureza }\end{array}$ & & & \\
\hline $\begin{array}{l}\text { 3. Ciências } \\
\text { Humanas }\end{array}$ & & & \\
\hline & EQUIPE PEDAGÓGICA E DIREÇÃO & \\
\hline $\begin{array}{l}\text { Coordenador } \\
\text { Pedagógico }\end{array}$ & & & \\
\hline $\begin{array}{l}\text { Orientador } \\
\text { Educacional }\end{array}$ & & & \\
\hline $\begin{array}{l}\text { Supervisor } \\
\text { Educacional }\end{array}$ & & & \\
\hline Direção & & & \\
\hline Equipe Pedagógica & & & \\
\hline Psicólogo(a) & & & \\
\hline
\end{tabular}

RESPONSÁVEL PELO ALUNO

\begin{tabular}{|l|l|}
\hline Nome & Telefone:
\end{tabular}

Cidade:

Data 1

Referência bibliográfica: MEC/SEESP. Saberes e Práticas da Inclusão: recomendações para a construção de escolas inclusivas.

Brasília: Ministério da Educação, secretaria de educação especial, 2005. 


\section{ANEXO III}

TERMO DE CONSENTIMENTO LIVRE E ESCLARECIDO - TCLE

(Professora, pais dos participantes, direção)

\section{Professora regente ${ }^{55}$}

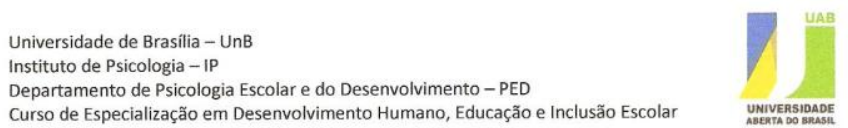

Curso de Especialização em Desenvolvimento Humano, Educação e Inclusão Escolar

UNIIERSIDADE

TERMO DE CONSENTIMENTO LIVRE E ESCLARECIDO

Senhor(a) Professor(a),

Sou orientanda do Curso de Especialização em Desenvolvimento Humano, Educação e Inclusão Escolar, realizado pelo Instituto de Psicologia por meio da Universidade Aberta do Brasil- Universidade de Brasilia (UAB-UnB) e estou realizando um estudo sobre A APRENDIZAGEM MATEMÁTICA NO CONTEXTO DA SALA DE RECURSOS: INTERAÇÕES E ADEQUAÇÕES CURRICULARES NO PROCESSO ENSINO-APRENDIZAGEM. Este estudo poderá fornecer às instituições de ensino subsídios para o planejamento de atividades, com vistas à promoção de condições favoráveis ao pleno desenvolvimento dos alunos em contextos inclusivos e, ainda, favorecer 0 processo de formação continuada dos professores neste contexto de ensino.

A estratégia metodológia desta pesquisa envolve analisar algumas atividades matemáticas realizadas em sala de aula regular que serão objetos de pesquisa em Sala de Recursos, após resolução pelos alunos escolhidos, com o objetivo de levantar dificuldades em realizá-las e propor as adequações necessárias que visem o sucesso acadêmico dos alunos que apresentam alguma necessidade especial. Dessa forma, haverá necessidade de gravações em video das atividades realizadas e, possivelmente, entrevistas gravadas em áudio (e/ou por escrito) com professores e alunos no intuito de colher o máximo de informações que possam subsidiar as atividades realizadas durante a pesquisa. Para isso, solicito sua autorização para a participação no estudo.

Esclareço que esta participação é voluntária. Você poderá deixar a pesquisa a qualquer momento que desejar, sem que isto the acarrete qualquer prejuizo. Asseguro-lhe que sua identificação não será divulgada em hipótese alguma e que os dados obtidos serão mantidos em total sigilo, sendo analisados coletivamente.

55 A identificação da professora regente foi omitida, garantindo o sigilo quanto aos seus dados, assegurado por meio desta documentação. 
Caso tenha alguma dúvida sobre o estudo, o(a) senhor(a) poderá me contatar pelo telefone 9979-6042 ou no endereço eletrônico raipitagoras@hotmail.com. Se tiver interesse em conhecer os resultados desta pesquisa, por favor, indique um e-mail de contato.

Agradeço antecipadamente sua atenção e colaboração.

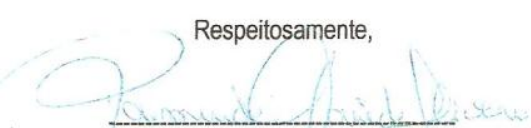

Raimunda Maria de Oliveira

Orientanda do Curso de Especialização em Desenvolvimento Humano, Educação e Inclusão Escolar da UAB - UnB.

Concorda em participar do e $e^{c^{4}}$ Ido? ( $) \operatorname{Sim}($ ) Não

Nome:

Assinatura:

E-mail (opcional): 


\section{Mãe de Pedro ${ }^{56}$}

Departamento de Psicologia Escolar e do Desenvolvimento - PED

Curso de Especialização em Desenvolvimento Humano, Educação e Inclusão Escolar

Senhores Pais ou responsáveis,

Sou orientanda do Curso de Especialização em Desenvolvimento Humano, Educação e Inclusão Escolar, realizado pelo Instituto de Psicologia por meio da Universidade Aberta do Brasil- Universidade de Brasília (UAB-UnB) e estou realizando um estudo sobre A APRENDIZAGEM MATEMÁTICA NO CONTEXTO DA SALA DE RECURSOS: INTERAÇÕES E ADEQUAÇÕES CURRICULARES NO PROCESSO ENSINO-APRENDIZAGEM. Este estudo poderá fornecer às instituições de ensino subsídios para o planejamento de atividades, com vistas à promoção de condições favoráveis ao pleno desenvolvimento dos alunos em contextos inclusivos e, ainda, favorecer o processo de formação continuada dos professores neste contexto de ensino.

A estratégia metodológia desta pesquisa envolve analisar algumas atividades matemáticas realizadas em sala de aula regular que serão objetos de pesquisa em Sala de Recursos, após resolução pelos alunos escolhidos, com o objetivo de levantar dificuldades em realizá-las e propor as adequações necessárias que visem o sucesso acadêmico dos alunos que apresentam alguma necessidade especial. Dessa forma, haverá necessidade de gravações em vídeo das atividades realizadas e, possivelmente, entrevistas gravadas em áudio (e/ou por escrito) com professores e alunos no intuito de colher o máximo de informações que possam subsidiar as atividades realizadas durante a pesquisa. Para isso, solicito sua autorização para a participação no estudo.

Esclareço que esta participação é voluntária. Você poderá deixar a pesquisa a qualquer momento que desejar, sem que isto the acarrete qualquer prejuizo. Asseguro-lhe que sua identificação não será divulgada em hipótese alguma e que os dados obtidos serão mantidos em total sigilo, sendo analisados coletivamente.

56 A identificação da mãe foi omitida, garantindo o sigilo quanto aos seus dados, assegurado por meio desta documentação. 
Caso tenha alguma dúvida sobre 0 estudo, o(a) senhor(a) poderá me contatar pelo telefone.9979-6042 ou no endereço eletrônico raipitagoras@hotmail.com. Se tiver interesse em conhecer os resultados desta pesquisa, por favor, indique um e-mail de contato.

Agradeço antecipadamente sua atenção e colaboração.

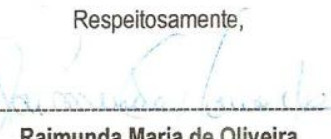

Raimunda Maria de Oliveira

Orientanda do Curso de Especialização em Desenvolvimento Humano, Educação e Inclusāo Escolar da UAB - UnB.

Concorda em particip? do estudo? ( ) Sim ( ) Não

Nome.

Assinatura:

E-mail (opcional): 


\section{Pai de Ana Júlia ${ }^{57}$}

Universidade de Brasília - UnB

Instituto de Psicologia - IP

Departamento de Psicologia Escolar e do Desenvolvimento - PED

Curso de Especialização em Desenvolvimento Humano, Educação e Inclusão Escolar

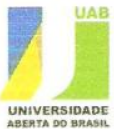

TERMO DE CONSENTIMENTO LIVRE E ESCLARECIDO

Senhores Pais ou responsáveis,

Sou orientanda do Curso de Especialização em Desenvolvimento Humano, Educação e Inclusão Escolar, realizado pelo Instituto de Psicologia por meio da Universidade Aberta do Brasil- Universidade de Brasília (UAB-UnB) e estou realizando um estudo sobre A APRENDIZAGEM MATEMÁTICA NO CONTEXTO DA SALA DE RECURSOS: INTERAÇÕES E ADEQUAÇÕES CURRICULARES NO PROCESSO ENSINO-APRENDIZAGEM. Este estudo poderá fornecer às instituições de ensino subsídios para o planejamento de atividades, com vistas à promoção de condições favoráveis ao pleno desenvolvimento dos alunos em contextos inclusivos e, ainda, favorecer o processo de formação continuada dos professores neste contexto de ensino

A estratégia metodológia desta pesquisa envolve analisar algumas atividades matemáticas realizadas em sala de aula regular que serão objetos de pesquisa em Sala de Recursos, após resolução pelos alunos escolhidos, com o objetivo de levantar dificuldades em realizá-las e propor as adequações necessárias que visem o sucesso acadêmico dos alunos que apresentam alguma necessidade especial. Dessa forma, haverá necessidade de gravações em vídeo das atividades realizadas e, possivelmente, entrevistas gravadas em áudio (e/ou por escrito) com professores e alunos no intuito de colher o máximo de informações que possam subsidiar as atividades realizadas durante a pesquisa. Para isso, solicito sua autorização para a participação no estudo.

Esclareço que esta participação é voluntária. Você poderá deixar a pesquisa a qualquer momento que desejar, sem que isto the acarrete qualquer prejuizo. Asseguro-lhe que sua identificação não será divulgada em hipótese alguma e que os dados obtidos serão mantidos em total sigilo, sendo analisados coletivamente.

57 A identificação do pai foi omitida, garantindo o sigilo quanto aos seus dados, assegurado por meio desta documentação. 
Caso tenha alguma dúvida sobre o estudo, o(a) senhor(a) poderá me contatar pelo telefone 9979-6042 ou no endereço eletrônico raipitagoras@hotmail.com. Se tiver interesse em conhecer os resultados desta pesquisa, por favor, indique um e-mail de contato.

Agradeço antecipadamente sua atençăo e colaboraçăo.

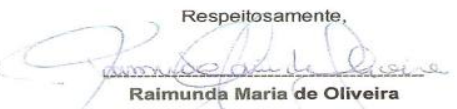

Orientanda do Curso de Especializaçăo em Desenvolvimento Humano, Educaçăo e Inclusão Escolar da UAB - UnB.

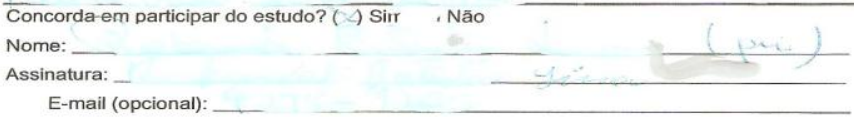




\section{Direção da Instituição de Ensino onde foi realizada a pesquisa}

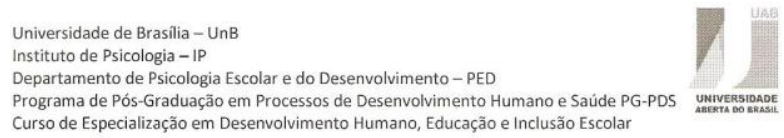

Programa de Pós-Graduação em Processos de Desenvolvimento Humano e Saúde PG-PDS

Curso de Especialização em Desenvolvimento Humano, Educação e Inclusão Escolar

$A(0)$ Diretor(a)

Centro de Ensino Fundamental 01 de Sobradinho

De: Profa. Dra. Diva Albuquerque Maciel

Coordenadora Geral do Curso de Especialização em Desenvolvimento Humano,

Educação e Inclusão Escolar

Assunto: Coleta de Dados para Monografia

Senhor (a), Diretor (a),

A Universidade Aberta do Brasil - Universidade de Brasília está em processo de realização da 1 a oferta do curso de Especialização em Desenvolvimento Humano, Educação e Inclusão Escolar, do qual seis dentre as 20 turmas ofertadas são de professores e educadores da rede pública do DF (polos UAB-UnB de Santa Maria e Ceilandia), além de alunos inscritos em outros pólos, mas que atuam nesta rede. Finalizamos agora a 1ạ fase do curso e estamos iniciando a Orientação de Monografia.

É requisito parcial para a conclusão do curso, a realização de um estudo empírico sobre tema acerca da inclusão no contexto escolar, cujas estratégias metodólgicas podem envolver: entrevista com colegas, pais ou outros participantes; observação; e análise documental.

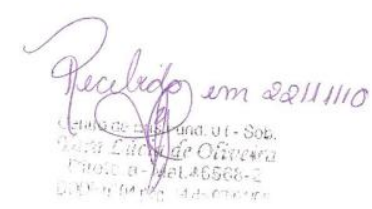


A realização desses trabalhos tem como objetivo a formação continuada dos professores/servidores da rede pública, subsidiando-os no desenvolvimento de uma prática pedagógica refletida e transformadora, tendo como conseqüência uma educação inclusiva.

Informo que foi autorizado pela Secretaria de Educação por meio do Memorando no 496/EAPE, datado de 09/11/2010, a realização das coletas de dados para as pesquisas na Rede Pública de Ensino do Distrito Federal.

Informações a respeito dessa autorização podem ser verificadas junto a Secretaria de Educação.

O trabalho será realizado pelo Professor/cursista Raimunda Maria de Oliveira sob orientação da professora Doutora Gabriela Sousa Melo Mieto cujo tema é: A APRENDIZAGEM MATEMÁTICA NO CONTEXTO DA SALA DE RECURSOS: INTERAÇÕES E ADEQUAÇÕES CURRICULARES NO PROCESSO ENSINO-APRENDIZAGEM.

Desde já agradeço, colocando-me a disposição de Vossa Senhoria para maiores esclarecimentos nos telefones (061) 3107-6831.

Atenciosamente,

\section{Diva Albuquerque Maciel}

Coordenadora Geral do Curso de Especialização em Desenvolvimento Humano,

Educação e Inclusão Escolar 
1) A seguir está representada uma multiplicação em que os algarismos, $\Delta$ is $\square$ o desconhecidos. Qual o valor da soma $\tilde{z}+\Delta+\square$ ?

Observação: Algarismos da mesma cor são iguais.

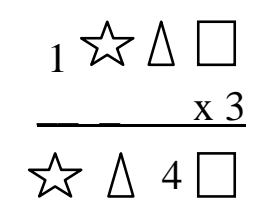
a) 5
b) 8
c) 11
d) 14

2) Um trem faz o percurso da estação $A$ até a estação $B$ em 2 horas 22 minutos e 35 segundos. Se o trem chegou na estação $B$ exatamente às 10 horas, o seu horário de partida da estação A foi:
a) 6 horas 38 minutos e 35 segundos
b) 6 horas 37 minutos e 25 segundos
c) $\quad 7$ horas 37 minutos e 25 segundos
d) 7 horas 38 minutos e 35 segundos

3) Quando o conteúdo de um reservatório é escoado por uma bomba, o tempo necessário é de 1 hora, 37 minutos e 42 segundos. Se forem utilizadas 2 bombas, o tempo necessário para esvaziar será de:
a) 46 minutos e 21 segundos
b) 47 minutos e 21 segundos
c) 48 minutos e 51 segundos
d) 48 minutos e 21 segundos

4) Um copo cheio de água pesa $325 \mathrm{~g}$. Se jogarmos metade da água fora, seu peso cai para $180 \mathrm{~g}$. O peso do copo vazio é:
a) $\quad 20 \mathrm{~g}$ 

b) $\quad 25 \mathrm{~g}$
c) $\quad 35 \mathrm{~g}$
d) $\quad 40 \mathrm{~g}$

5) Dirceu mora no Edíficio Três Andares a 1990 dias. Há quantos meses e quantos dias Dirceu mora nesse edifício?
a) 63 meses e 10 dias
b) 62 meses e 12 dias
c) 66 meses e 10 dias
d) 60 meses e 10 dias

6) A imagem abaixo possui simetria:
a) Horizontat
b) Vertical
c) Diagonal
d) Horizontal e vertical

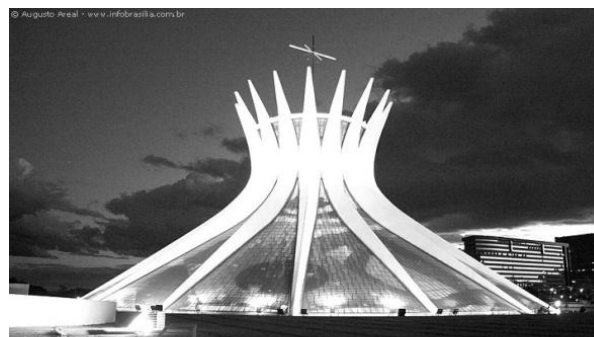

7) A forma de potência que pode representar a conta 6.6.6.6.6.6.6.6.6 é:
a) $6^{10}$
b) $6^{9}$
c) $10^{6}$
d) $9^{6}$
8) Se um número possui base 9 e o expoente é 8:
a) $\quad 8.9$
b) $\quad 9: 8$
c) $\quad 9^{8}$
d) $8^{9}$ 
9) O resultado de $3^{3}+2^{2}$ é:

a) 27

b) 4

c) 31

d) 11

Nas questões 9, 10 e 11 o enunciado das questões é o seguinte:

No ginásio de esportes de Sobradinho há 3.250 lugares para o público. Na decisão de um torneio intercolegial de futebol de salão, compareceram ao ginásio 2628 pessoas, sendo 1863 homens.

10) Quantas mulheres compareceram?
a) 2387
b) 2383
c) 1245
d) 765

11) Quantos lugares ficaram vazios?

a) 622

b) 2413

c) 1393

d) 1438

12) Nos jogos do dia anterior, 1384 lugares haviam ficado vazios. Quantas pessoas compareceram no dia anterior?
a) 1866
b) 1364
c) 2006
d) 1756 
13) O valor da potência $7^{2}$ é:

a) 14

b) 49

c) 41

d) 9

14) A potência $2^{3} \cdot 2^{2}$

a) 24

b) $2^{5}$

c) $\quad 2^{6}$

d) 42

15) A torre digital terá 180 metros, se quisermos falar esta altura em centímetros o número falado, será:
a) $\quad 180000$
b) 18000
c) $\quad 1800$
d) 1,80

16) A unidade de medida mais adequada para medir o tamanho do mastro da bandeira na praça dos três poderes:
a) quilômetros
b) litros
c) quilogramas
d) metros
O valor das expressões é:

17) $40: 8+2.16$
a) 112
b) 37
c) 1
d) 64 
18) $40:(8+2.16)$
a) 112
b) 37
c) 1
d) 64

19) $40:(8+2) \cdot 16$
a) 112
b) 37
c) 1
d) 64

20) $(40: 8+2) .16$
a) 112
b) 37
c) 1
d) 64 


\section{ANEXO V}

ATIVIDADE ADAPTADA PELA PESQUISADORA

01. Um trem faz um percurso da Estação de Sá até a Estação de Ouro em 180 minutos. Se o trem chegou à Estação de Ouro às 10 horas, qual o horário de partida da Estação de Sá?

02. Dirceu mora no Edifício Três Andares há 200 dias. Quantos meses isso representa?

03. A figura a seguir, representa a imagem da Catedral de Brasília. Essa construção possui eixo de simetria horizontal ou vertical?

Marque esse eixo de simetria na figura.

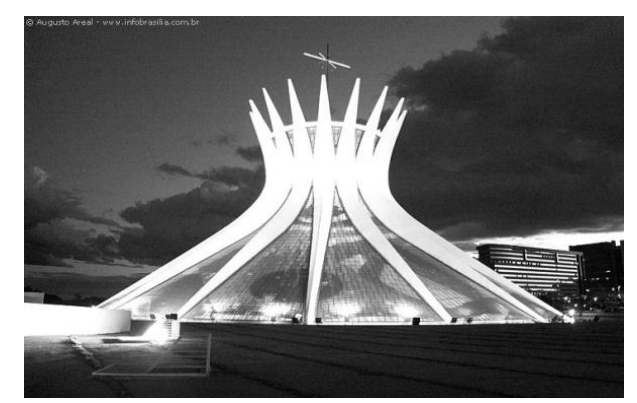

04. Qual é o resultado da potência $5^{3}$ ?

05. Em uma sala, há 3 mesas com 3 gavetas em cada uma. Cada gaveta contém 3 pastas e em cada pasta há 3 cadernos. Representando em forma de potência a situação apresentada, calcule o número total de cadernos.

06. No ginásio de esportes de Sobradinho há 3250 lugares para o público. Na decisão de um torneio intercolegial de futebol de salão, compareceram ao ginásio 2628 pessoas, sendo 1863 homens. Quantas mulheres compareceram? 
07. Quantos cm tem um metro?

08. A Torre Digital terá 180 metros de altura. Qual será o valor da altura dessa torre se considerarmos como unidade de medida o centímetro?

09. A unidade de medida mais adequada para medir o tamanho do mastro da bandeira na praça dos três poderes é quilômetros, litros, quilogramas ou metros?

10. Qual o resultado da expressão numérica $40:(8+2)$. 16 ? 


\section{Ana Júlia}

3) Quando o conteúdo de um reservatório é escoado por uma bomba, o tempo necessário é de 1 hora, 37 minutos e 42 segundos. Se forem utilizadas 2 bombas, o tempo necessário para esvaziar será de:

a) 46 minutos e 21 segundos

b) 47 minutos e 21 segundos

c) 48 minutos e 51 segundos 2 hivilas

d) 48 minutos e 21 segundos +42

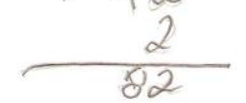

4) Um copo cheio de água pesa $325 \mathrm{~g}$. Se jogarmos metade da água fora, seu peso cai para $180 \mathrm{~g}$. O peso do copo vazio é:

a) $20 \mathrm{~g}$

b) $25 \mathrm{~g}$

c) $35 \mathrm{~g}$

d) $40 \mathrm{~g}$

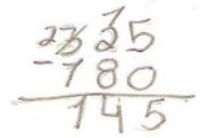

5) Dirceu mora no Edíficio Três Andares a 1990 dias. Há quantos meses e quantos dias Dirceu mora nesse edifício?

a) 63 meses e 10 dias ummôs 30 dias 60 b) 62 meses e 12 dias 2 mes 60

c) 66 meses e 10 dias

d) 60 meses 10 dias
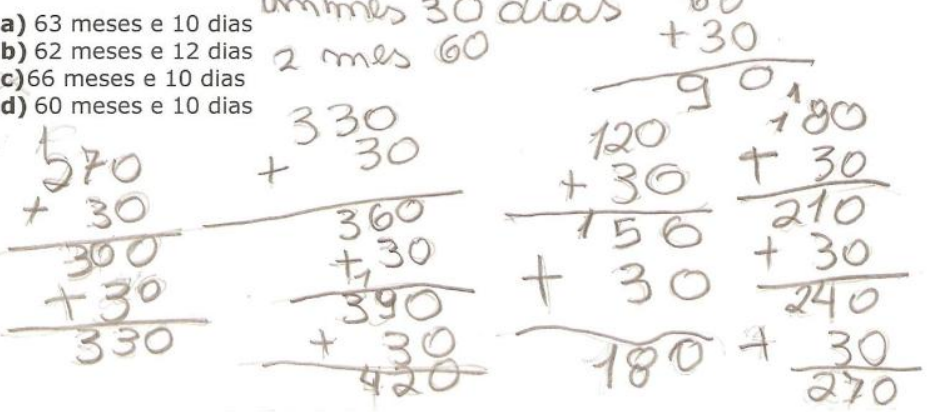


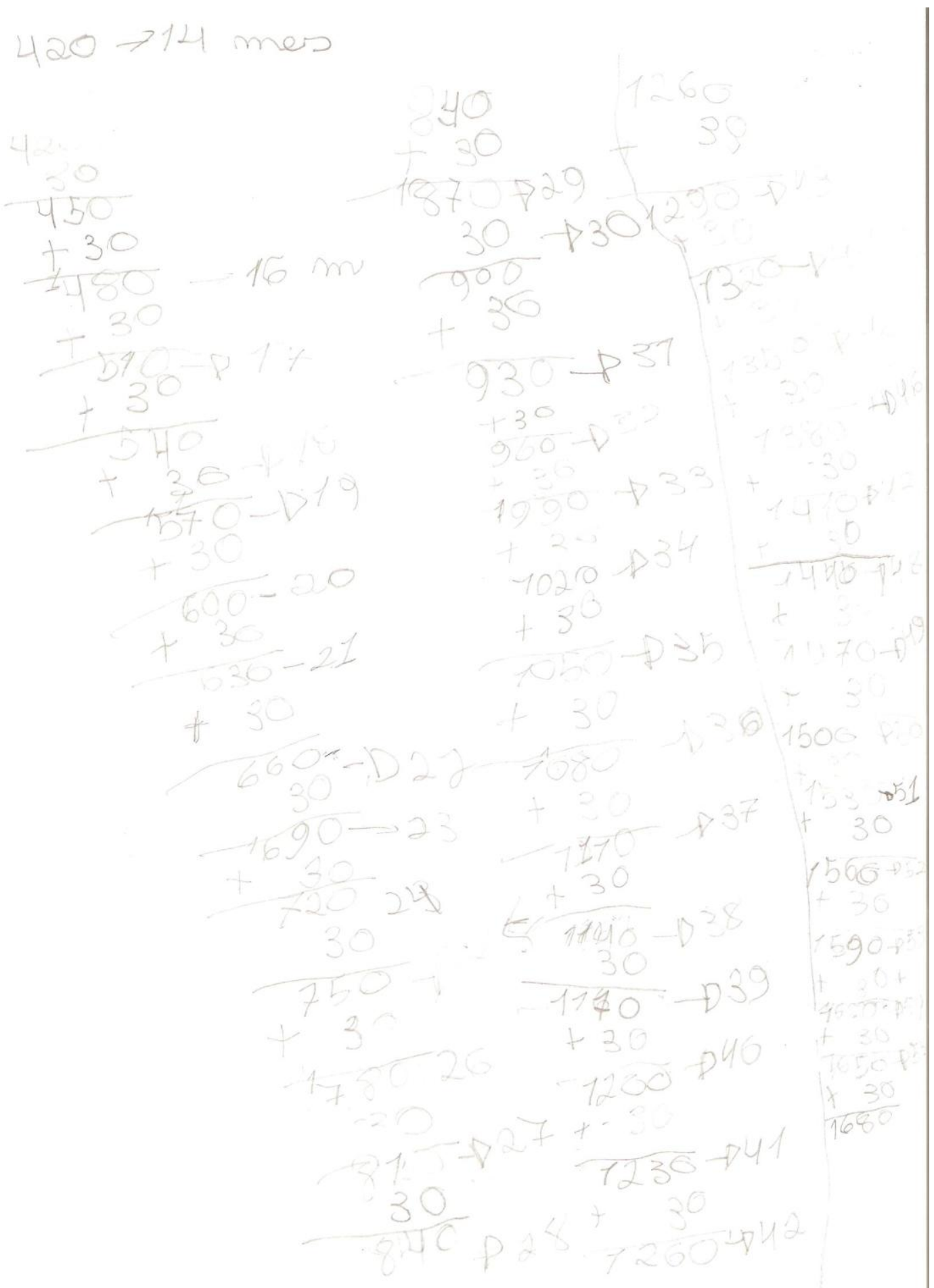


6) A imagem abaixo possui simetria:

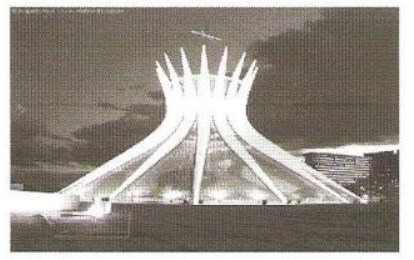

a) Horizontal

b) Vertical

c) Diagonal

d) Horizontal e vertical

7) A forma de potência que pode representar a conta 6.6.6.6.6.6.6.6.6 é:
a) $6^{10}$
b) $6^{9}$
c) $10^{6}$
d) $9^{6}$
a) 8.9
b) $9: 8$
c) $9^{8}$
d) $8^{9}$

8) Se um número possui base 9 e o expoente é 8 : 


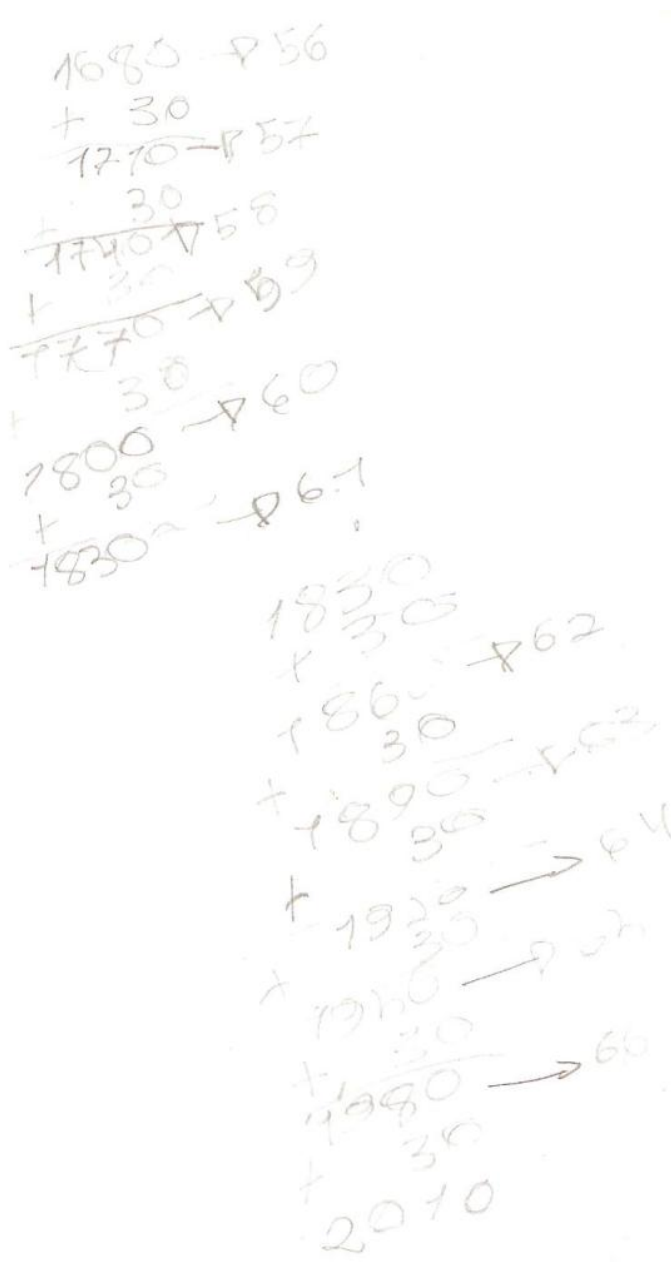


9) O resultado de $3^{3}+2^{2}$ é:
a) 27
b) 4
c) 31
d) 11

Nas questões 9, 10 e 11 o enunciado das

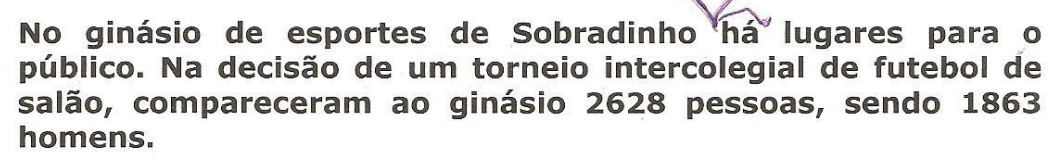

No ginásio de esportes de Sobradinho há lugares para o público. Na decisão de um torneio intercolegial de futebol de salão, compareceram ao ginásio 2628 pessoas, sendo 1863 homens.

10) Quantas mulheres compareceram?
a) 2387
b) 2383
c) 1245
di) 765

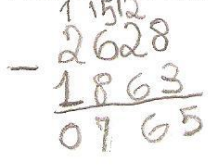

11) Quantos Jugares ficaram vazios?
a) 622
b) 2413
e) 1393
d) 1438

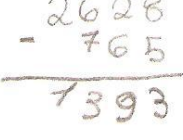


12) Nos jogos do dia anterior, 1384 lugares haviam ficado vazios. Quantas pessoas compareceram no dia anterior?
a) 1866
b) 1364
c) 2006
d) 1756

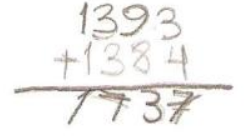

$13 \frac{9}{3} 3^{1}$

13) $O$ valor da potência $7^{2}$ é:

a) $14 \quad 797=49$

c) 41

d) 9 
14)

A potência $2^{3} \cdot 2^{2}$

a) 24

b) $2^{5}$

$2 \times 2 \times 2 \times 2 \times 2=10$

d) 42

15) A torre digital terá 180 metros, se quisermos falar esta altura em centímetros o número falado, será:
a) 180000
b) 18000
nas entemali
c) 1800
d) 1,80

16) A unidade de medida mais adequada para medir o tamanho do mastro da bandeira na praça dos três poderes:

a) quilômetros netro

b) litros

c) quilogramas

d) metros

nâo, eltro poroue náo é agua

nâo magario o quilogramo Porgue lu nōo sei $\theta$ quer

nâo maquei quilometro porque 


\section{O valor das expressões é:}

17)

$40: 8+2.16$

a) 112

b) 37

c) 1

d) 64

18) $40:(8+2.16)$

a) 112

b) 37

c) 1

d) 64

19) $40:(8+2) \cdot 16$
a) 112
b) 37
c) 1
d) 64

20) $(40: 8+2) \cdot 16$

a) 112

b) 37

c) 1

d) 64

Obs.: Ana Júlia não realizou os exercícios nº 1 e 2. 


\section{Pedro}

1) A seguir está representada uma multiplicação em que os algarismos $\tilde{u}^{2} \Delta$ e $\square$ são desconhecidos. Qual o valor da soma $\hat{s}+\Delta+\square$ ?

Observação: Algarismos da mesma cor são iguais.

$\frac{1}{1}$ 出 $\bar{\Delta}$

$\frac{\times 3}{445}$

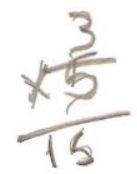

5

b) 8

c) 11

d) 14

2) Um trem faz o percurso da estação $A$ até a estação $B$ em 2 horas 22 minutos e 35 segundos. Se o trem chegou na estação B exatamente às 10 horas, o seu horário de partida da estação
A foi:

a) 6 horas 38 minutos e 35 segundos

t) 6 horas 37 minutos e 25 segundos

c) 7 horas 37 minutos e 25 segundos

d) 7 horas 38 minutos e 35 segundos

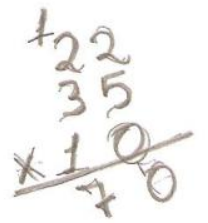


3) Quando o conteúdo de um reservatório é escoado por uma bomba, o tempo necessário é de 1 hora, 37 minutos e 42 segundos. Se forem utilizadas 2 bombas, o tempo necessário para esvaziar será de:

a) 46 minutos e 21 segundos

10) 47 minutos e 21 segundos

c) 48 minutos e 51 segundos

d) 48 minutos e 21 segundos
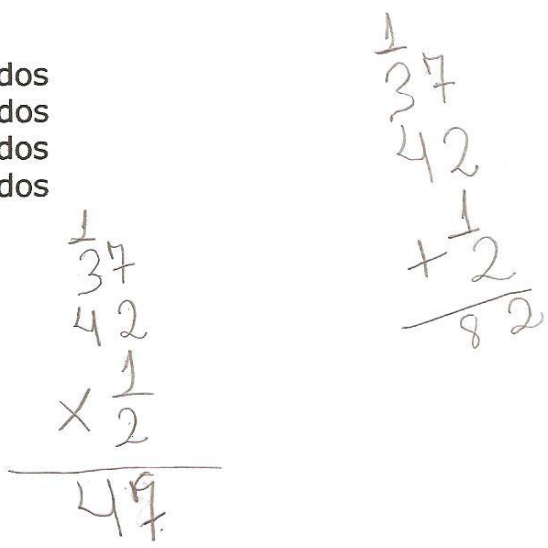

4) Um copo cheio de água pesa $325 \mathrm{~g}$. Se jogarmos metade da água fora, seu peso cai para $180 \mathrm{~g}$. O peso do copo vazio é:
a) $20 \mathrm{~g}$
b) $25 \mathrm{~g}$
c) $35 \mathrm{~g}$
d) $40 \mathrm{~g}$
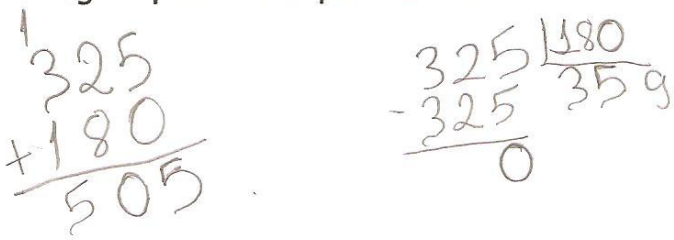

5) Dirceu mora no Edíficio Três Andares a 1990 dias. Há quantos meses e quantos dias Dirceu mora nesse edifício?

a) 63 meses e 10 dias

b) 62 meses e 12 dias

c) 66 meses e 10 dias

d) 60 meses e 10 dias 
6) A imagem abaixo possui simetria:

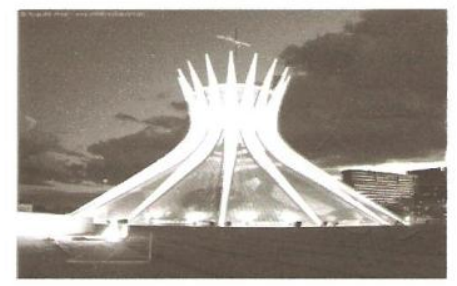
a) Horizontal
is Vertical
c) Diagonal
d) Horizontal e vertical

7) A forma de potência que pode representar a conta 6.6.6.6.6.6.6.6.6 é:
a) $6^{10}$
b) $6^{9}$
c) $10^{6}$
(x) $9^{6}$

8) Se um número possui base 9 e o expoente é 8:

a) 8.9

b) $9: 8$

e. $9^{8}$

d) $8^{9}$ 
9) 0 resultado de $3^{3}+2^{2}$ é:
a) 27
b) 4
c) 31
d) 11
e) 13
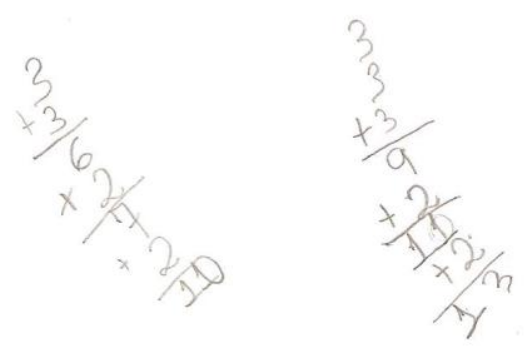

Nas questões 9, 10 e 11 e enunciado das questões é o seguinte:

No ginásio de esportes de Sobradinho há lugares para o público. Na decisão de um torneio intercolegial de futebol de salão, compareceram ao ginásio 2628 pessoas, sendo 1863 homens.

10) Quantas mulheres compareceram?
a) 2387
b) 2383
c) 1245
d) 765
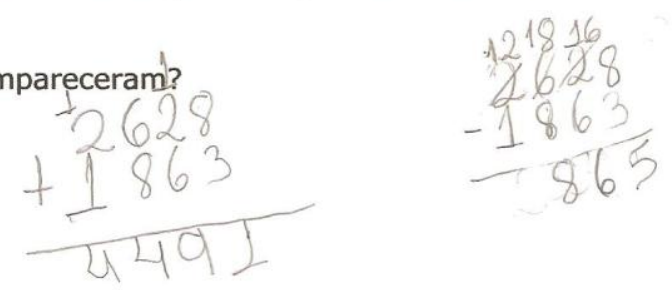

11) Quantos lugares ficaram vazios?
a) 622
b) 2413
c) 1393
d) 1438

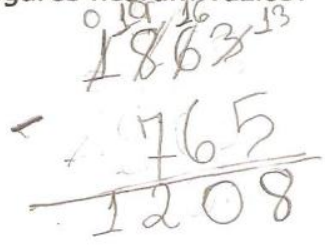


12) Nos jogos do dia anterior, 1384 lugares haviam ficado vazios. Quantas pessoas compareceram no dia anterior?
a) 1866
b) 1364
c) 2006
d) 1756

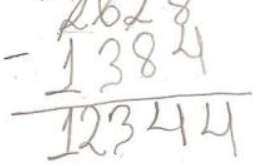

13) $O$ valor da potência $7^{2}$ é:

a) 14

b) 49

c) 41

d) 9

$7 \times 7=49$ 
14) A potência $2^{3} \cdot 2^{2}$

$\begin{array}{ll}\text { a) } 24 & 2 \times 2 \times 2=8 \\ \text { b) } 2^{5} & 2^{6} \\ \text { d) } 42 & 2 \times 2=4 \times 4 \\ 42\end{array}$

15) A torre digital terá 180 metros, se quisermos falar esta altura em centímetros o número falado, será:
a) 180000
b) 18000
c) 1800
d) 1,80

16) A unidade de medida mais adequada para medir o tamanho do mastro da bandeira na praça dos três poderes: metroy
a) quilômetros
b) litros
c) quilogramas
d) metros 


\section{O valor das expressões é:}

17) $40: 8+2.16$

a) 112

b) $3740: 8+52$

c) $1640: 62$

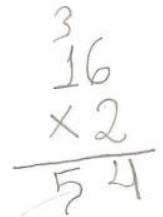

18) $40:(8+2 \cdot 16)$

a) 112

c) 1

d) 64

19) $40:(8+2) \cdot 16$

a) 112

b) 37

c) 1

d) 64

20) $(40: 8+2) \cdot 16$

a) 112

b) 37

c) 1

d) 64 


\section{Ana Júlia}

01. Um trem faz um percurso da Estação de Sá até a Estação de Ouro em 180 minutos. Se o trem chegou à estação de Ouro às 10 horas, qual o horário de partida da Estação de Sá?
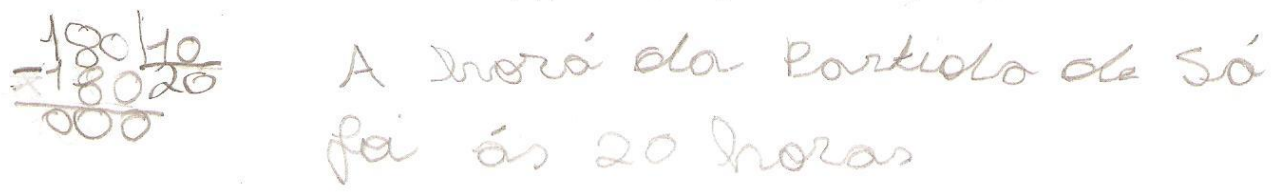

02. Dirceu mora no Edifício Três Andares há 200 dias. Quantos meses isso representa?

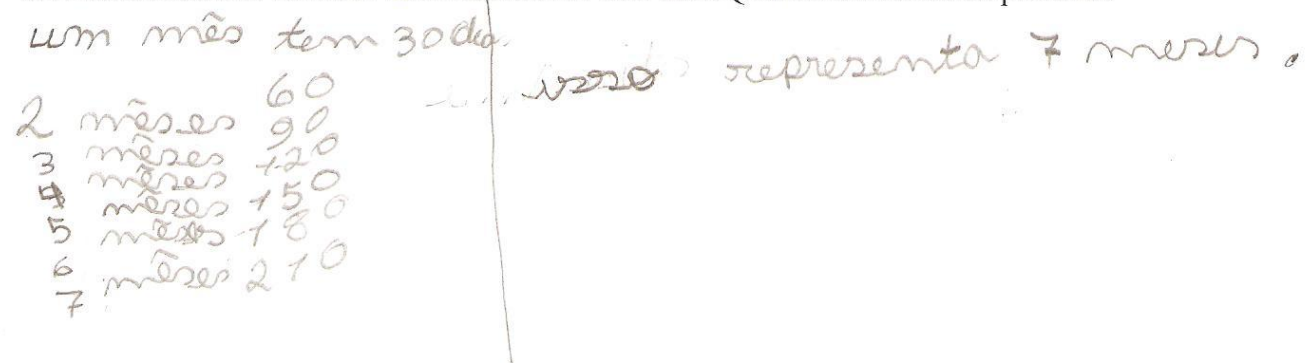

03. A figura a seguir, representa a imagem da Catedral de Brasília. Essa construção possui eixo de simetria horizontal ou vertical?

Marque esse eixo na figura.

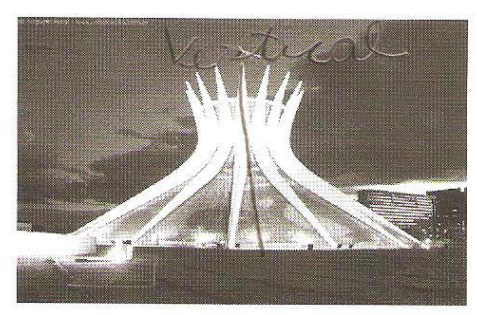


04. Qual é o resultado da potência $5^{3}$ ?

$$
\begin{array}{r}
5 \cdot 5 \cdot 5 \cdot=125+25 \\
+\quad 5 \\
\hline 125
\end{array}
$$

05. Em uma sala, há 3 mesas com 3 gavetas em cada uma. Cada gaveta contém 3 pastas e em cada pasta há 3 cadernos. Representando em forma de potência a situação apresentada, calcule o número total de cadernos.

06. No ginásio de esportes de Sobradinho há 3250 lugares para o público. Na decisão de um torneio intercolegial de futebol de salão, compareceram ao ginásio 2628 pessoas, sendo 1863 homens. Quantas mulheres compareceram?

$$
\begin{aligned}
& 23^{1 / 2} 2^{14} 5^{10} \\
& 28.63 \\
& \frac{-1863}{1387} \\
& \text { coporeseram } \\
& 1387 \text { mulhe } \\
& \text { res }
\end{aligned}
$$


07. Quantos cm tem 1 metro?

08. A Torre Digital terá 180 metros de altura. Qual será o valor da altura dessa torre se considerarmos como unidade de medida o centímetro?

09. A unidade de medida mais adequada para medir o tamanho do mastro da bandeira na praça dos três poderes é quilômetros, litros, quilogramas ou metros?

10. Qual o resultado da expressão numérica $40:(8+2) \cdot 16 ?$

$40:(8+2), 16$ 


\section{Pedro}

01. Um trem faz um percurso da Estação de Sá até a Estação de Ouro em 180 minutos. Se o trem chegou à estação de Ouro às 10 horas, qual o horário de partida da Estação de Sá?

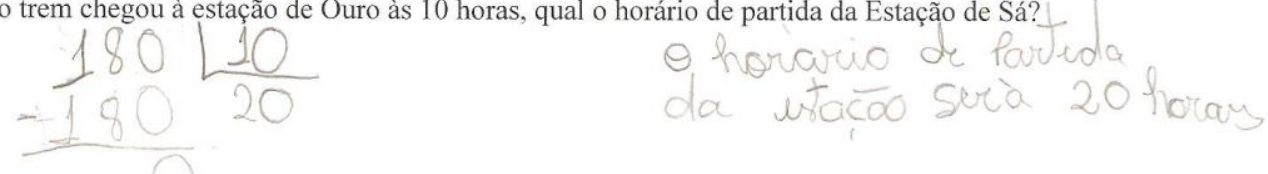

02. Dirceu mora no Edifício Três Andares há 200 dias. Quantos meses isso representa?

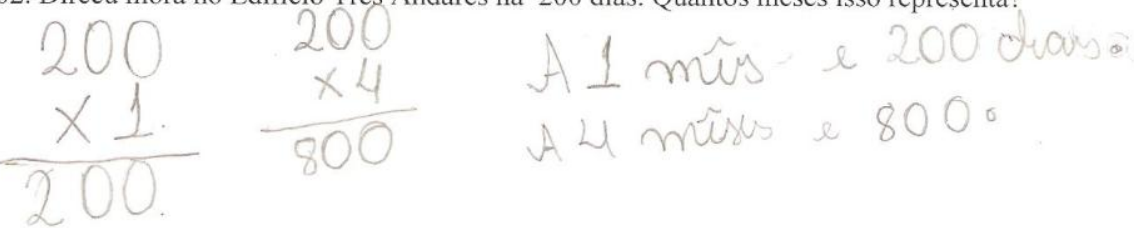

03. A figura a seguir, representa a imagem da Catedral de Brasília. Essa construção possui eixo de simetria horizontal ou vertical? ?ertic of Marque esse eixo na figura.

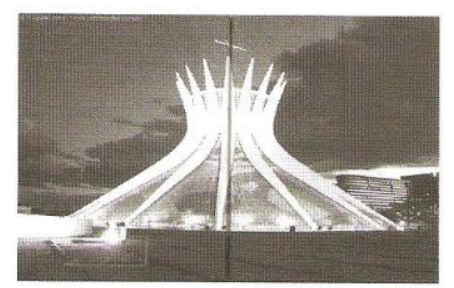


04. Qual é o resultado da potência $5^{3}$ ?

$$
5 \times 5=25 \times 5=125
$$

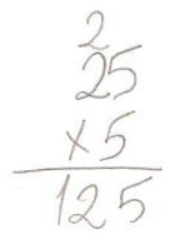

05. Em uma sala, há 3 mesas com 3 gavetas em cada uma. Cada gaveta contém 3 pastas e em cada pasta há 3 cadernos. Representando em forma de potência a situação apresentada, calcule o número total de cadernos.

$3 \times 3=9$

27 ladurnos

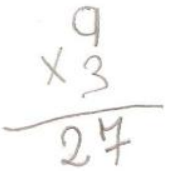

06. No ginásio de esportes de Sobradinho há 3250 lugares para o público. Na decisão de um torneio intercolegial de futebol de salão, compareceram ao ginásio 2628 pessoas, sendo 1863 homens. Quantas mulheres compareceram?
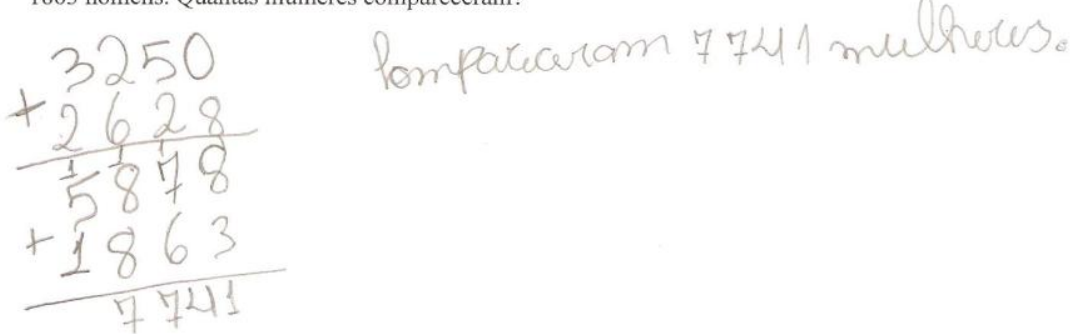
07. Quantos $\mathrm{cm}$ tem 1 metro?

08. A Torre Digital terá 180 metros de altura. Qual será o valor da altura dessa torre se considerarmos como unidade de medida o centímetro?

09. A unidade de medida mais adequada para medir o tamanho do mastro da bandeira na praça dos três poderes é quilômetros, litros, quilogramas ou metros?

mejorys

10. Qual o resultado da expressão numérica $40:(8+2) .16$ ?

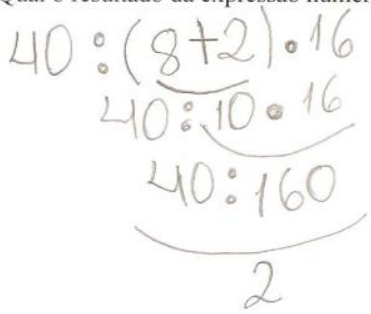




\section{ANEXO VIII}

\section{ATIVIDADE REALIZADA PELOS PARTICIPANTES EM INTERAÇÃO}

\section{Ana Júlia e Pedro}

01. Um trem faz um percurso da Estação de Sá até a Estação de Ouro em 180 minutos. Se o trem chegou à estação de Ouro às 10 horas, qual o horário de partida da Estação de Sá?
2 horay tim $\$ 120 \mathrm{~m}$
3 horay tem $\$ 180 m$

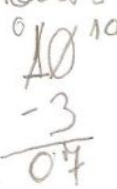
um hora tem 60 iminutos. (1) hocaxio de

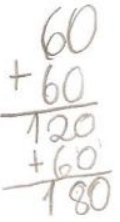 rartica da uteces de Sá sera 7 horas

02. Dirceu mora no Edifício Três Andares há 200 dias. Quantos meses isso representa? 7 musus ferm 210 dias
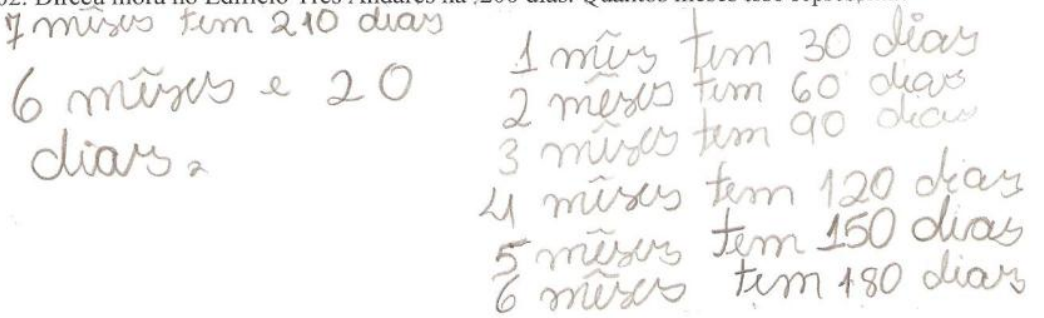

03. A figura a seguir, representa a imagem da Catedral de Brasília. Essa construção possui eixo de simetria horizontal ou vertical? Vertical

Marque esse eixo na figura. gente salop que évertecal for que fisimos Um frabalro soble ele.

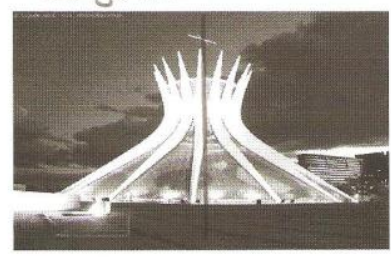


0 Qual é o resultado da potência $5^{3}$ ?

$$
\begin{aligned}
& \frac{5 \cdot 5}{25} \cdot 5 \cdot=125 \\
& \begin{array}{r}
2 \\
25 \\
\times 5 \\
\hline 125
\end{array}
\end{aligned}
$$

04. Em uma sala, há 3 mesas com 3 gavetas em cada uma. Cada gaveta contém 3 pastas e em cada pasta há 3 cadernos. Representando em forma de potência a situação apresentada, calcule o número total de cadernos.

$$
\begin{array}{r}
3 \times 3=9 \\
\times 3 \\
\hline 27
\end{array}
$$

06. No ginásio de esportes de Sobradinho há 3250 lugares para o público. Na decisão de um torneio intercolegial de futebol de salão, compareceram ao ginásio 2628 pessoas, sendo 1863 homens. Quantas mulheres compareceram?

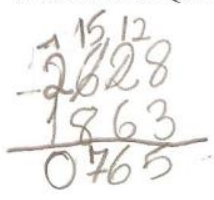

fompourecerom 765 multures. 
07. Quantos cm tem 1 metro? 100

06. A Torre Digital terá 180 metros de altura. Qual será o valor da altura dessa torre se considerarmos como unidade de medida o centímetro?

09. A unidade de medida mais adequada para medir o tamanho do mastro da bandeira na praça dos três poderes é quilômetros, litros, quilogramas ou metros?

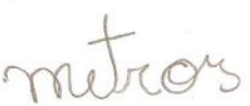

10. Qual o resultado da expressão numérica $40:(8+2) .16$ ?

$$
\begin{array}{r}
\Delta 0:(8+2) \cdot 16 \\
\frac{40: 10: 16}{40: 160}
\end{array}
$$


